Alana de Fátima Andrade Santos

AVALIAÇÃO TOXICOLÓGICA DA AYAHUASCA EM RATOS WISTAR: COMPORTAMENTO E TOXICIDADE REPRODUTIVA EM MACHOS

BRASÍLIA, 2016 


\author{
UNIVERSIDADE DE BRASÍLIA \\ FACULDADE DE CIÊNCIAS DA SAÚDE \\ PROGRAMA DE PÓS-GRADUAÇÃO EM CIÊNCIAS DA SAÚDE
}

ALANA DE FÁTIMA ANDRADE SANTOS

AVALIAÇÃO TOXICOLÓGICA DA AYAHUASCA EM RATOS WISTAR: COMPORTAMENTO E TOXICIDADE REPRODUTIVA EM MACHOS

Dissertação apresentada como requisito parcial para a obtenção do Título de Mestre em Ciências da Saúde, pelo Programa de Pós-Graduação em Ciências da Saúde, da Universidade de Brasília.

Orientadora: Eloisa Dutra Caldas

Co-Orientadora: Aline Pic-Taylor

Brasília, 2016 
UNIVERSIDADE DE BRASÍLIA, BRASÍLIA

ALANA DE FÁTIMA ANDRADE SANTOS

\title{
AVALIAÇÃO TOXICOLÓGICA DA AYAHUASCA EM RATOS WISTAR: COMPORTAMENTO E TOXICIDADE REPRODUTIVA EM MACHOS
}

Dissertação apresentada como requisito parcial para a obtenção do Título de Mestre em Ciências da Saúde, pelo Programa de Pós-Graduação em Ciências da Saúde, da Universidade de Brasília.

\author{
BANCA EXAMINADORA \\ Prof $^{\mathrm{a}}$. Dr ${ }^{\mathrm{a}}$. Eloisa Dutra Caldas (Presidente) \\ Universidade de Brasília \\ Prof $^{\mathrm{a}}$. Dr ${ }^{\mathrm{a}}$. Carolina Madeira Lucci \\ Universidade de Brasília \\ Prof. Dr. Anderson Joel Martino Andrade \\ Universidade Federal do Paraná \\ $\operatorname{Prof}^{a}$. Dr ${ }^{a}$. Daniela Mara de Oliveira (Suplente) \\ Universidade de Brasília
}




\section{AGRADECIMENTOS}

À minha orientadora Eloisa Dutra Caldas e co-orientadora Aline Pic-Taylor por me "adotarem" ainda na graduação me proporcionando conhecimento ao longo dos programas de Iniciação Científica. Por depositarem em mim a confiança necessária para a realização deste trabalho e por serem exemplos de mulheres e pesquisadoras excepcionais.

A nossa equipe de pesquisa: Luciana Gueiros, Juliana, Luciana Nolli, William, Karina, Nágela e Marcus pela amizade adquirida durante os vários anos de trabalho, pelas boas risadas nos momentos de descontração, pelos conhecimentos compartilhados e por toda ajuda prestada durante o estudo.

Às alunas Karina, Camila, Stefany e Muriel, pela prestatividade e dedicação.

A todos os estagiários que passaram pelo Laboratório de Embriologia e Biologia do Desenvolvimento e que contribuíram de forma importantíssima para a realização desse projeto.

Aos técnicos e servidores do Instituto de Biologia e da Faculdade de Saúde, em especial ao veterinário Rafael e ao Emiraldo e sua equipe do biotério por serem sempre dedicados e cuidadosos com os animais.

À patologista Ana Luiza pela parceria firmada e dedicação nas análises histológicas.

A Glorinha, técnica histológica, por ceder o seu espaço para a realização de uma etapa desse estudo e por compartilhar todos os seus ensinamentos e experiências adquiridas durante sua carreira acadêmica.

À União do Vegetal por ceder a ayahuasca utilizada nesse projeto.

Ao Instituto Sabin pela parceria nas análises sorológicas.

À FAP-DF e a CAPES pelo fomento dos estudos.

Aos meus pais: Sueli e Cézar; meus irmãos: Amanda, André e Alex; e meus sobrinhos: Caio e Heitor. Simplesmente por existirem!

Aos grandes amigos: Linniker, Júnior, Dyana e Thaís por todos os momentos divertidos e por todos os conselhos já passados a mim.

A Dona Silvia e Seu Lourival pela amizade e sabedoria.

\section{A Deus pela vida!}


A biologia prova a simplicidade e sofisticação de Deus. 


\section{Sumário}

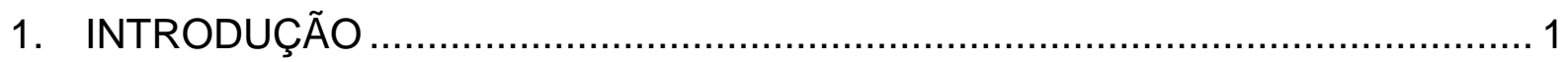

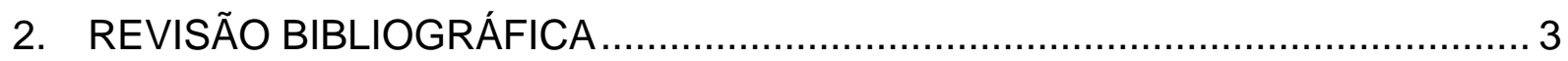

2.1. Origem da ayahuasca e seu consumo no contexto religioso ......................... 3

2.2. Espécies botânicas e composição química da ayahuasca ............................ 5

2.2.1. Banisteriopsis caapi .................................................................. 5

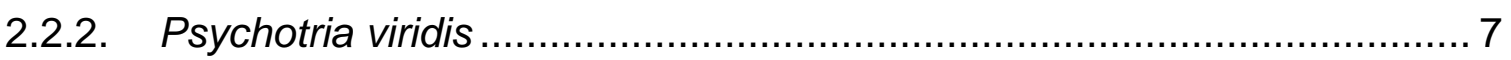

2.3. Farmacologia dos componentes da ayahuasca ....................................... 9

2.4. Efeitos biológicos e psíquicos da ayahuasca ......................................... 13

2.5. Potencial terapêutico da ayahuasca ........................................................ 13

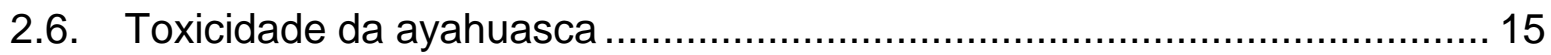

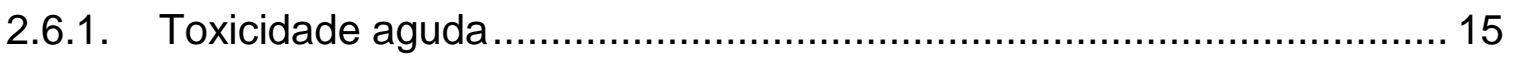

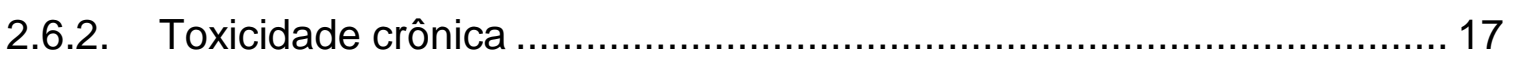

2.6.3. Toxicidade reprodutiva ................................................................... 19

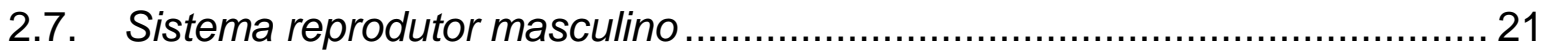

2.8. Avaliação da função reprodutiva no macho............................................ 25

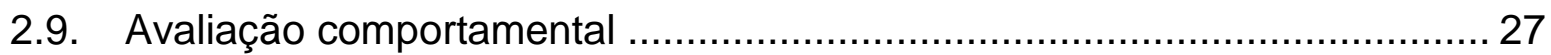

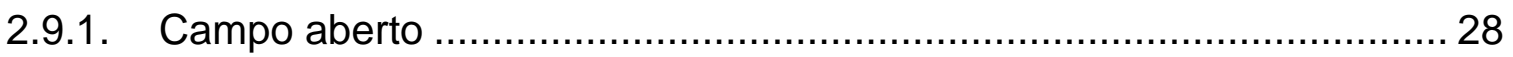

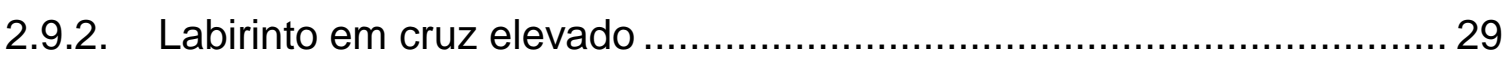

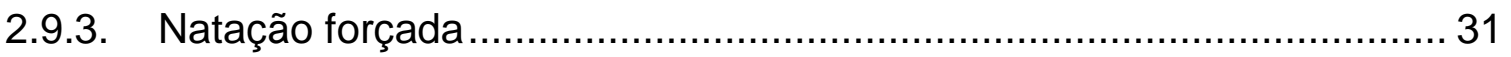

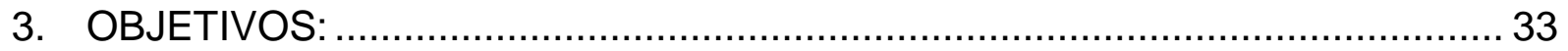

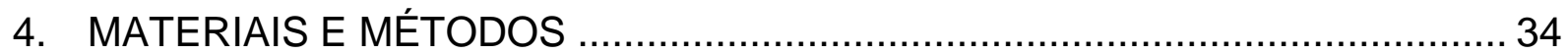

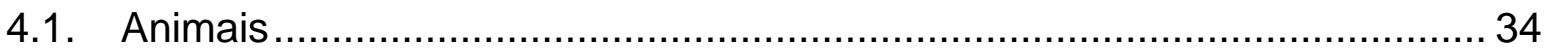

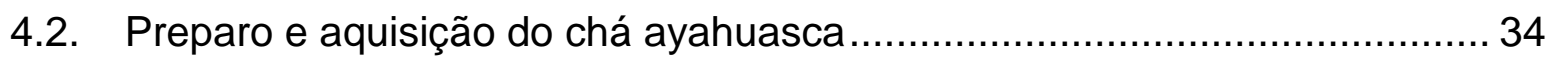

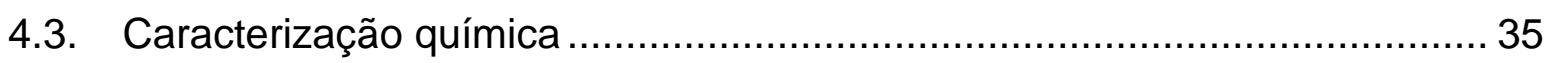

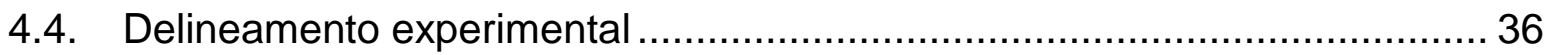

4.5. Eutanásia e coleta de material biológico ………..................................... 37

I. AVALIAÇÃO COMPORTAMENTAL DA AYAHUASCA EM RATOS MACHOS

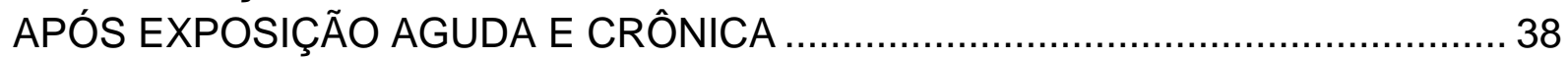

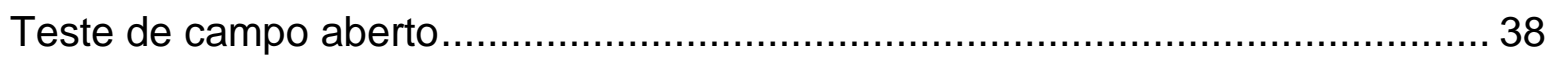

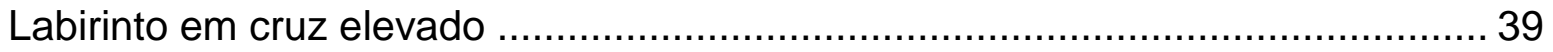

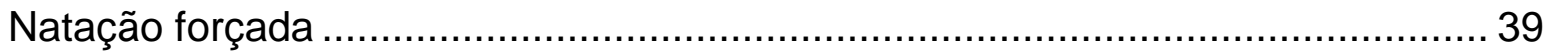

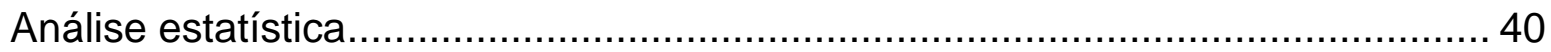

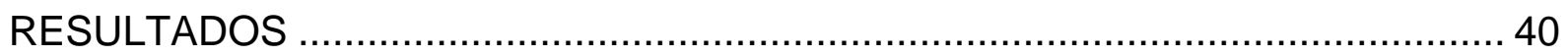




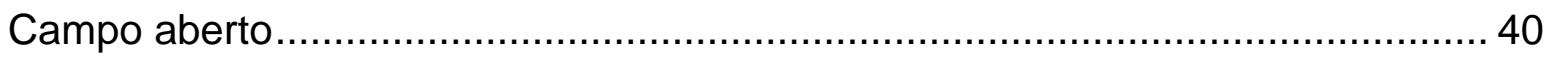

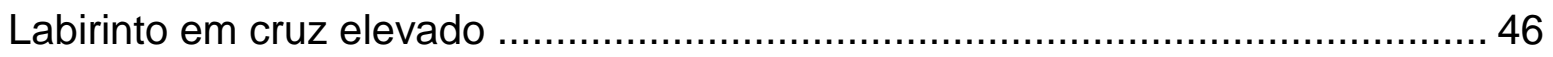

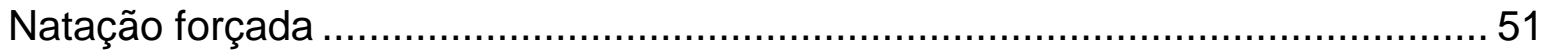

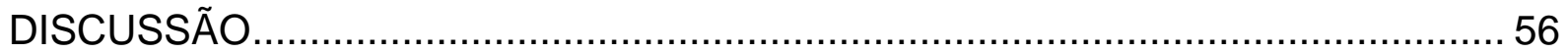

II. AVALIAÇÃO DA TOXICIDADE REPRODUTIVA MASCULINA DA AYAHUASCA

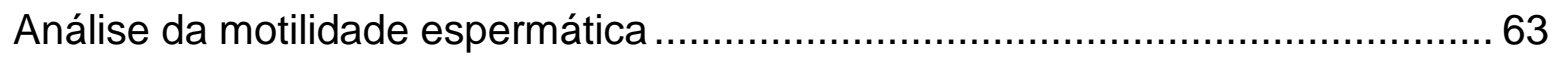

Contagem total de espermatozoides, produção espermática diária e tempo de

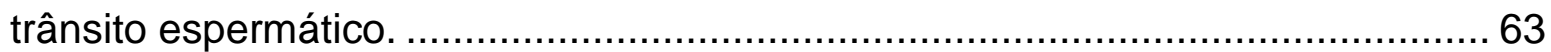

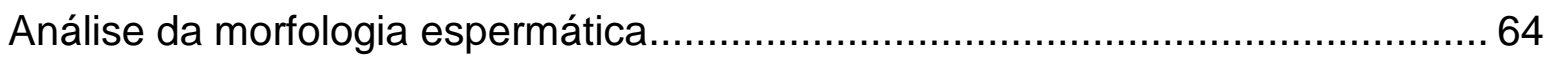

Processamento histológico do testículo e epidídimo ...........................................65

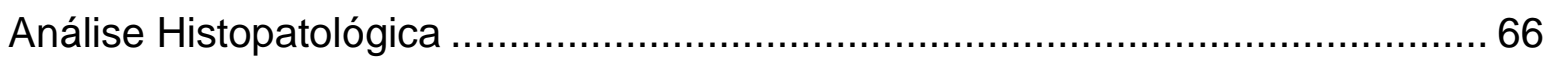

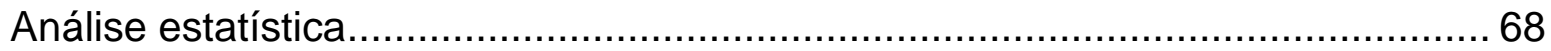

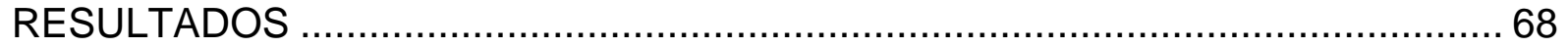

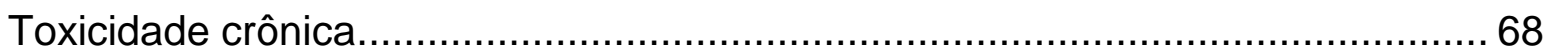

Motilidade e morfologia espermática ........................................................ 73

Produção espermática diária, reserva espermática na cauda do epidídimo e tempo de trânsito espermático. ....................................................................... 74

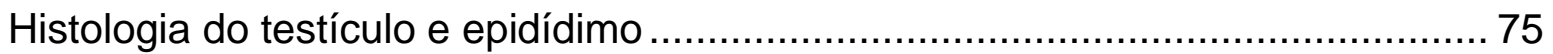

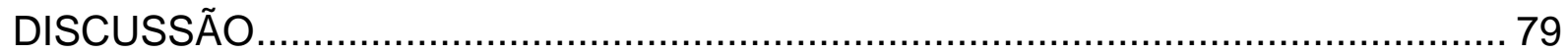

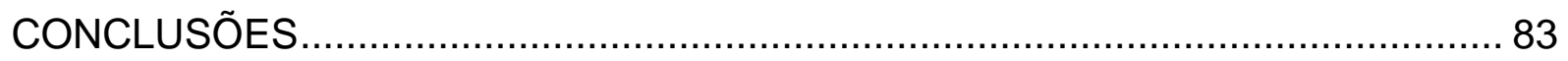

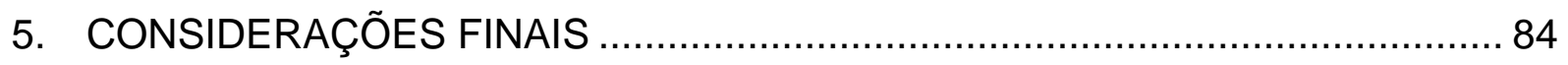

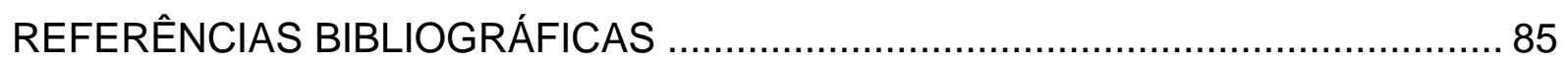

ANEXO I - APROVAÇÃO DO COMITÊ DE ÉTICA …........................................... 96 


\section{Lista de Figuras}

Figura 1. Banisteriopsis caapi. Fonte: Foto tirada no Núcleo Luz do Oriente (UDV), Brazlândia-DF. 6

Figura 2. Estrutura molecular dos alcaloides $\beta$-carbolínicos, $N, N$ - dimetiltriptamina (DMT) e serotonina (5HT). 7

Figura 3. Psychotria viridis. Fonte: www.botanicalspirit.com.

Figura 4. Regulação pré-sináptica da neurotransmissão da 5HT. Fonte: Golan, 2009, p.188.

Figura 5. Estrutura química dos alucinógenos indoleaminas (LSD) e

indolalquilaminas (DPT, DMT, 5Meo-DMT, psilocibina e psilocina). 12

Figura 6. Seção de um túbulo seminífero mostrando a maturação celular e o progresso das células em direção ao lúmen dando origem aos espermatozoides. Fonte: Sadler, 2011, p. 24

Figura 7. Testículo seccionado e sua conexão com o epidídimo. Fonte: Netter, 2000.

Figura 8. Eixo hipotálamo - hipófise - gônada. (-) indica retroalimentação negativa. Fonte: (http://wikiciencias.casadasciencias.org/wiki/index.php/Regulação-SistemasReprodutores) Adaptado. 24

Figura 9. Aparato para realização do teste de Campo Aberto ................................ 29

Figura 10. Aparato para realização do teste de Labirinto em Cruz Elevado ............. 30

Figura 11. Cilindro de acrílico usado para o teste de Natação Forçada ................... 32

Figura 12. Preparo do chá ayahuasca pela UDV ……....................................... 35

Figura 13. Procedimento de gavagem utilizando sonda flexível ........................... 37

Figura 14. Parâmetros de locomoção, entradas no quadrante central, elevação e autolimpeza avaliados no teste do Campo Aberto, 1 hora após a primeira gavagem, nos animais do grupo controle negativo, controle positivo (FLX) e tratados com ayahuasca. Valores expressos em Média \pm SEM. Letras diferentes representam diferença significativa.

Figura 15. Relação da locomoção na área central pela locomoção total avaliada no Campo Aberto, 1 hora após a primeira gavagem nos animais do grupo controle negativo, controle positivo (FLX) e tratados com ayahuasca. Valores expressos em Média \pm SEM. Letras diferentes representam diferença significativa. 
Figura 16. Parâmetro de defecação avaliado no teste do Campo Aberto, 1 hora após a primeira gavagem, nos animais do grupo controle negativo, controle positivo (FLX) e tratados com ayahuasca. Valores expressos em Média \pm SEM. Letras diferentes representam diferença significativa.

Figura 17. Parâmetros de locomoção, elevação e autolimpeza avaliados no teste do Campo Aberto, no $36^{\circ}$ dia de tratamento, nos animais do grupo controle negativo, controle positivo (FLX) e tratados com ayahuasca. Valores expressos em Média \pm SEM. Letras diferentes representam diferença significativa.

Figura 18. Frequência de idas ao quadrante central $(A)$ e relação entre a locomoção na área central pela locomoção total $(B)$ avaliada no teste do Campo Aberto, no $36^{\circ}$ dia de tratamento, nos animais do grupo controle negativo, controle positivo (FLX) e tratados com ayahuasca. Valores expressos em Média \pm SEM. Letras diferentes representam diferença significativa.

Figura 19. Parâmetros de locomoção, idas ao quadrante central, elevação e autolimpeza avaliados no teste do Campo Aberto, no $70^{\circ}$ dia de tratamento, nos animais do grupo controle negativo, controle positivo (FLX) e tratados com ayahuasca. Valores expressos em Média \pm SEM.

Figura 20. Frequência de idas ao quadrante central $(A)$ e relação entre a locomoção na área central pela locomoção total $(B)$, dos animais do grupo controle positivo, controle negativo e tratados com ayahuasca, avaliada no teste do Campo Aberto no $36^{\circ}$ dia de tratamento e no $70^{\circ}$ dia de tratamento; $\downarrow$ indica diminuição; mudanças estatisticamente significativas quando $p \leq 0,05$.

Figura 21. Tempo de permanência no braço fechado (BF), braço aberto (BA), e no centro, dos animais do grupo controle negativo, controle positivo e tratados com ayahuasca, avaliado no Labirinto em Cruz Elevado, 1 hora após a primeira gavagem.

Figura 22. Tempo de permanência no braço fechado (BF), braço aberto (BA), e no centro, dos animais do grupo controle negativo, controle positivo e tratados com ayahuasca, avaliado no Labirinto em Cruz Elevado, no $36^{\circ}$ dia de tratamento (metade).

Figura 23. Tempo de permanência no braço fechado (BF), braço aberto (BA), e no centro, dos animais do grupo controle negativo, controle positivo e tratados com ayahuasca, avaliado no Labirinto em Cruz Elevado, no $70^{\circ}$ dia de tratamento (final). 
Figura 24. Tempo de permanência no braços fechados $(A)$, braços abertos $(B)$ e no centro $(C)$ dos animais do grupo controle negativo, controle positivo e tratados com ayahuasca durante a segunda avaliação ( $\left.36^{\circ} \mathrm{dia}\right)$ e terceira $\left(70^{\circ} \mathrm{dia}\right)$ no Labirinto em Cruz Elevado; $\uparrow$ indica aumento, $\downarrow$ indica diminuição; mudanças estatisticamente significativas quando $p \leq 0,05$.

Figura 25. Parâmetros de natação, imobilidade e climbing avaliados no teste de Natação Forçada 1 hora após a primeira gavagem, nos animais do grupo controle negativo, controle positivo e tratados com ayahuasca.

Figura 26. Parâmetros de natação, imobilidade e climbing avaliados no teste de Natação Forçada no $36^{\circ}$ dia de tratamento, nos animais do grupo controle negativo, controle positivo e tratados com ayahuasca. Letras diferentes representam diferença significativa.

Figura 27. Parâmetros de natação, imobilidade e climbing avaliados no teste de Natação Forçada no $70^{\circ}$ dia de tratamento, nos animais do grupo controle negativo, controle positivo e tratados com ayahuasca. Letras diferentes representam diferença significativa.

Figura 28. Quantidade de bolos fecais verificada no teste de Natação Forçada, 1 hora após a primeira gavagem (A), no $36^{\circ}$ dia de tratamento (B) e no $70^{\circ}$ dia (C) nos animais do grupo controle negativo, controle positivo e tratados com ayahuasca. Valores expressos em Média \pm SEM. Letras diferentes representam diferença significativa.

Figura 29. Parâmetros de natação $(A)$, imobilidade (B) e climbing $(C)$ avaliados no teste de Natação Forçada durante a segunda avaliação ( $36^{\circ}$ dia) e terceira $\left(70^{\circ} \mathrm{dia}\right)$, dos animais do grupo controle negativo, controle positivo e tratados com ayahuasca; $\uparrow$ indica aumento, $\downarrow$ indica diminuição; mudanças estatisticamente significativas quando $p \leq 0,05$.

Figura 30. Parâmetros morfológicos avaliados: a. espermatozoide normal, b. espermatozoide sem cabeça, c. cabeça achatada, d. pescoço dobrado, e. cabeça com curvatura reduzida, f. cauda curvada, g. cauda enrolada, h. múltiplas anormalidades.

Figura 31. Percentual de espermatozoides progressivos (A) e morfologicamente normais (B) dos animais do grupo controle e tratados com ayahuasca (Média \pm SEM). 
Figura 32. Produção espermática diária (A); reserva espermática na cauda do epidídimo (B) e tempo de trânsito espermático $(C)$ dos animais do grupo controle e tratados com ayahuasca. Valores expressos em média \pm SEM $(p<0,05)$

Figura 33. Cortes histológicos de testículo dos ratos do grupo controle e tratados com ayahuasca. A: Túbulos seminíferos de um animal do grupo controle com ausência de alterações (aumento 100X). B: Túbulos seminíferos de um animal do grupo 4X apresentando esfoliação intensa de células germinativas (seta sem preenchimento) e edema intenso (setas com preenchimento) (aumento 100X). C: Túbulo de um animal do grupo 4X mostrando vacuolização (setas) (aumento 400X). D: Túbulos de um animal do grupo $2 X$ com redução do diâmetro e desorganização celular (seta) (aumento 100X). Coloração H\&E.

Figura 34. Seções longitudinais das regiões do corpo (A e B) e cabeça (C) do epidídimo dos animais do grupo controle e tratados com ayahuasca. A: Túbulo epididimário de um animal do grupo $1 \mathrm{X}$ com ausência de alterações e densidade espermática normal (aumento 100X). B: Túbulo epididimário de um animal do grupo controle apresentando células da linhagem espermatogênica (setas) e hiposespermia discreta a moderada (aumento 200X). C: Corte histológico de um animal do grupo $1 \mathrm{X}$ mostrando infiltrado inflamatório intersticial (setas) (aumento 200X). Coloração H\&E 


\section{Lista de Tabelas}

Tabela 1. Parâmetros avaliados no teste do labirinto em cruz elevado nos animais do grupo controle negativo, controle positivo (FLX) e tratados com ayahuasca, 1 hora após a primeira gavagem. Valores expressos em Média \pm SEM, n=12.

Tabela 2. Parâmetros avaliados no teste do labirinto em cruz elevado nos animais do grupo controle negativo, controle positivo (FLX) e tratados com ayahuasca, no $36^{\circ}$ dia de tratamento. Valores expressos em Média \pm SEM.

Tabela 3. Parâmetros avaliados no teste do labirinto em cruz elevado nos animais do grupo controle negativo, controle positivo e tratados com ayahuasca, no $70^{\circ}$ dia de tratamento. Valores expressos em Média \pm SEM.

Tabela 4. Ganho de peso total, consumo de ração e peso corpóreo ao final do tratamento dos animais do grupo controle e tratados com ayahuasca nas doses de 1X, 2X, 4X e 8X durante 70 dias alternados (Média \pm SEM).

Tabela 5. Peso relativo dos órgãos dos animais do grupo controle e tratados com ayahuasca nas doses de 1X, 2X, 4X e 8X (Média \pm SEM). (\% em relação ao peso corpóreo no final do tratamento).

Tabela 6. Peso absoluto dos órgãos dos animais do grupo controle e tratados com ayahuasca nas doses de $1 \mathrm{X}, 2 \mathrm{X}, 4 \mathrm{X}$ e $8 \mathrm{X}$ (Média \pm SEM).

Tabela 7. Dosagens enzimáticas dos animais do grupo controle e tratados com ayahuasca. Valores expressos em Média \pm SEM.

Tabela 8. Níveis hormonais de testosterona, hormônio luteinizante (LH) e folículo estimulante (FSH) dos animais do grupo controle e tratados com ayahuasca. Valores expressos em média \pm SEM.

Tabela 9. Percentual de espermatozoides anormais dos animais do grupo controle e tratados com ayahuasca. Valores expressos em média \pm SEM. 74

Tabela 10. Score Médio de Biópsia Tubular de Johnsen's (MJTBS) e incidência das alterações histopatológicas encontradas no testículo e epidídimo (cabeça/corpo) dos animais do grupo controle e tratados com ayahuasca, $\mathrm{n}(\%)$. 76

Quadro 1. Escore de Biópsia Tubular de Johnsen's 67 


\section{Siglas e abreviaturas}

$\sigma 1-$ Receptor Sigma 1

$5 \mathrm{HT}$ - Serotonina

BA - Braço Aberto

BF - Braço Fechado

BDNF - Fator neurotrófico derivado do cérebro

CEUA - Comitê de Ética do Uso Animal

CNEA - Cadastro Nacional de Entidades usuárias da ayahuasca

CONAD - Conselho Nacional Anti-drogas

CONFEN - Conselho Federal de Entorpecentes

DA - Dopamina

DHT - Diidrotestosterona

DIMED - Divisão médica do CONFEN

$\mathrm{DL}_{50}$ - Dose letal média

DMEM - Dulbecco's Modified Eagle Medium

DMT - N, N - Dimetiltriptamina

DPT - N, N - Dipropiltriptamina

FLX - Fluoxetina

FSH - Hormônio folículo estimulante

GnRH - Hormônio liberador de gonadotrofinas

H\&E - Hematoxilina e Eosina

HRL - Harmalina

HRM - Harmina

IMAO - Inibidores da monoamina oxidase

ISRS - Inibidores seletivos de recaptação de serotonina

LCE - Labirinto em cruz elevado

LH - Hormônio luteinizante 
LSD - Dietilamida do ácido lisérgico

MAO - Monoamina oxidase

MAO-A - Monoamina oxidase do tipo A

MAO-B - Monoamina oxidase do tipo B

MJTBS - Score médio de biópsia tubular de Johnsen's

$\mathrm{NE}$ - Norepinefrina

OECD - Organization for Economic Cooperation and Development

PBS - Tampão fosfato-salino

SERT - Transportador de serotonina

SHBG - Proteína ligadora de hormônios sexuais

TCA - Teste do campo aberto

TGO - Transaminase glutâmico oxalacética

TGP - Transaminase glutâmico pirúvica

THH - Tetrahidro-harmina

TNF - Teste de natação forçada

TPH - Triptofano hidroxilase

TUNEL - Terminal deoxynucleotidyl transferase Dutp Nick End Labeling

UDV - União do vegetal

VMAT - Transportador de monoaminas vesicular 


\section{RESUMO}

A ayahuasca é uma bebida sacramental utilizada tradicionalmente por tribos indígenas feita geralmente a partir da cocção da Banisteriopsis caapi e da Psychotria viridis, que contêm alcaloides $\beta$-carbolínicos e o alucinógeno $\mathrm{N}, \mathrm{N}$-dimetiltriptamina (DMT), respectivamente. Essa infusão foi incorporada em rituais religiosos cristãos no Brasil nos anos 1930 e expandida para outros países mais recentemente. O objetivo desse estudo foi investigar o potencial toxicológico reprodutivo da ayahuasca em ratos machos Wistar, assim como os efeitos neurocomportamentais após um tratamento crônico. A ayahuasca foi administrada por gavagem em dias alternados por 70 dias nas doses de 1X, 2X, 4X e 8X a dose utilizada em ritual religioso (12 animais/grupo). Avaliações comportamentais foram feitas 1 hora após a primeira gavagem (exposição aguda), no $36^{\circ}$ dia e no $70^{\circ}$ dia de tratamento, utilizando os testes de Campo Aberto, Labirinto em Cruz Elevado e Natação Forçada. Os animais foram eutanasiados 24 hs depois do último tratamento e os indicadores reprodutivos avaliados. Dois animais do grupo 8X foram a óbito minutos após o tratamento. Na primeira avaliação do Campo Aberto, houve uma diminuição significativa $(p<0,05)$ da locomoção dos animais do grupo $4 X$ em relação ao controle. Animais do grupo $1 \mathrm{X}$ mostraram uma diminuição significativa no tempo de permanência nos braços abertos do Labirinto em Cruz Elevado e um aumento do tempo nos braços fechados na avaliação realizada no $70^{\circ}$ dia comparado com o $36^{\circ}$ dia. Efeitos similares foram observados no grupo controle positivo (fluoxetina 10 $\mathrm{mg} / \mathrm{kg}$ ). No $70^{\circ} \mathrm{dia}$, observou-se um aumento do climbing nas paredes do aparato de Natação Forçada nos animais do grupo 8X em relação aos grupos $1 \mathrm{X}$ e 4X. Esse resultado pode sugerir uma potencial ação antidepressiva da ayahuasca a longo prazo, efeito que deve ser melhor investigado. Foi observada uma diminuição significativa no consumo de ração e no ganho de peso corpóreo dos animais do grupo $4 \mathrm{X}$ e $8 \mathrm{X}$, além de um aumento no peso relativo do cérebro e estômago dos animais do grupo $8 \mathrm{X}$, em relação ao controle. Houve um aumento significativo nos níveis sorológicos de testosterona total, diminuição no tempo de trânsito espermático e na reserva espermática na cauda do epidídimo nos animais expostos a dose de $4 \mathrm{X}$ em relação ao grupo controle. Não houve diferenças significativas na avaliação dos outros indicadores reprodutivos avaliados (motilidade e morfologia espermática e histologia do testículo e epidídimo). Esse estudo permitiu identificar um nível de efeito adverso não observado (NOAEL) da ayahuasca para efeitos reprodutivos em ratos Wistar machos na dose de $2 \mathrm{X}$ a dose usual ritualística, que corresponde a 0,6 $\mathrm{mg} / \mathrm{kg}$ pc DMT, 6,6 mg/kg pc harmina e 0,52 mg/kg pc harmalina.

Palavras-chave: ayahuasca, toxicidade reprodutiva masculina, ratos Wistar, histologia, testes comportamentais. 


\section{ABSTRACT}

Ayahuasca is a sacred beverage used traditionally by indigenous tribes and generally prepared with Banisteriopsis caapi and Psychotria viridis, which contain $\beta$-carbonyl alkaloids and the hallucinogen $\mathrm{N}, \mathrm{N}$-dimethyltriptamine (DMT), respectively. This infusion was incorporated in Christian religious rituals in Brazil in the 1930's, and expanded to other countries more recently. The objective of this study was to investigate the potential reproductive toxicological effects and the behavioral effects of the ayahuasca in male Wistar rats after a chronic exposure. Ayahuasca was administered by gavage every other day for 70 days at $1 \mathrm{X}, 2 \mathrm{X}, 4 \mathrm{X}$ and $8 \mathrm{X}$ the dose used in a religious ritual (12 animals per group). Behavior evaluations were performed using the Open Field, Elevated Plus-Maze and Forced Swimming tests 1 hour after the first gavage (acute exposure), at the $36^{\text {th }}$ and at the $70^{\text {th }}$ day of treatment. The animals were sacrificed 24 hours after the last treatment, and the reproductive endpoints evaluated. Two animals from the highest dose group died soon after treatment. In the first Open Field evaluation, there was a significant decrease $(p<0.05)$ in the locomotion of animals from the $4 X$ group compared to controls. Animals from $1 \mathrm{X}$ group showed a significant decrease in the time spent in the open arms of the Elevated Plus-Maze and an increase of this parameter in the closed arms at $70^{\text {th }}$ day compared with the evaluation at the $36^{\text {th }}$ day. Similar effects were observed for the positive control (fluoxetine $10 \mathrm{mg} / \mathrm{kg}$ ). We observed a significant increase in climbing behavior in the Forced Swimming test in the animals from the $8 \mathrm{X}$ group compared to the $1 \mathrm{X}$ and $4 \mathrm{X}$. This result may suggest a potential antidepressant effect of the ayahuasca, which should be investigated further. There was a significant decrease in food consumption and weight gain in the $4 \mathrm{X}$ and $8 \mathrm{X}$ animals compared to controls, and a significant increase in the relative weight of the brain and stomach of animals from the $8 \mathrm{X}$ group. There was a significant increase in the total serum testosterone levels, decrease in spermatic transit time and spermatic reserves in the epididymis caudae in the $4 \mathrm{X}$ dosed animals in comparison with controls. No significant changes were found in the other reproductive endpoints evaluated (sperm motility and morphology, and histology of the testis and epididymis). This study identified a no-observed-adverse-effect-level (NOAEL) for chronic and reproductive effects at $2 \mathrm{X}$ the ritualistic dose of ayahuasca in male Wistar rats, which corresponds to $0.60 \mathrm{mg} / \mathrm{kg}$ bw DMT, $6.6 \mathrm{mg} / \mathrm{kg} \mathrm{pc}$ harmine and $0,52 \mathrm{mg} / \mathrm{kg}$ bw harmaline.

Keywords: ayahuasca, male reproductive toxicity, Wistar rats, histology, behavior tests 


\section{INTRODUÇÃO}

A ayahuasca é uma infusão vegetal com propriedades alucinógenas, utilizada ancestralmente por povos indígenas (McKenna, 2004), produzida geralmente pela cocção da folha do arbusto Psychotria viridis, que contém o alucinógeno $\mathrm{N}, \mathrm{N}$ Dimetiltriptamina (DMT) e do cipó Banisteriopsis caapi, que contém os alcaloides $\beta$ carbolinas harmina, harmalina e tetrahidro-harmina, inibidores da monoamina oxidase (MAO) (McKenna, 1984; Callaway et al., 1996; Harvey \& Champe, 1998). Os efeitos alucinógenos resultantes da sua ingestão são consequentes da combinação sinérgica entre estes componentes (Callaway, 1996; Callaway et al., 1999).

O consumo da ayahuasca por outras populações no Brasil iniciou-se a partir da década de 1930 com o surgimento de religiões cristãs que utilizavam a bebida em seus rituais, porém o reconhecimento legal definitivo da sua utilização nesse contexto ocorreu somente em 2004 (CONAD, 2004; Macrae et al., 2004; Tupper, 2008). Nas últimas décadas, as religiões ayahuasqueiras chegaram a outros países da América do Sul, América do Norte, Europa e Ásia, o que levou também à expansão do seu uso recreativo.

Estudos sobre a saúde física e mental de membros das religiões ayahuasqueiras demonstram a não ocorrência de danos ao consumir a bebida nesse contexto. Estudos com usuários de longo prazo mostram que os efeitos fisiológicos agudos, bem como os efeitos subjetivos são relativamente benignos, com manutenção das funções cognitivas normais (Callaway et al., 1999; Grob et al., 1996). Segundo Mckenna (2004) a ayahuasca apresenta características com provável potencial terapêutico, podendo regularizar os índices de serotonina em condições de déficit ou ainda ser alvo no tratamento da dependência de álcool ou outras substancias de abuso. Estudo conduzido por este grupo de pesquisa mostrou que uma infusão de ayahuasca cedida pela União do Vegetal (UDV) possui potencial efeito antidepressivo em ratos tratados com dose única de 30 vezes a dose utilizada em uma cerimônia religiosa (Pic-Taylor et al., 2015).

Por outro lado, alguns estudos toxicológicos em animais têm demonstrado que a ayahuasca ou seus constituintes químicos podem ser prejudiciais em doses altas (Pires et al., 2010; da Motta, 2013). Estudo conduzido com ratas demonstrou 
que a administração crônica de ayahuasca principalmente nas doses mais altas (4X e $8 \mathrm{X}$ ) durante o período gestacional levou à toxicidade materna além de alterações nos índices reprodutivos, como diminuição no número de fetos e aumento no número de reabsorções, mesmo na dose 1X (da Motta, 2013). Estudos que avaliem o potencial tóxico da ayahuasca em ratos machos ainda são inexistentes na literatura. Portanto, diante do crescente número de adeptos nas religiões ayahuasqueiras no Brasil e no mundo, mais estudos são necessários na tentativa de se chegar a um consenso sobre a segurança do uso dessa cocção.

O objetivo deste estudo foi avaliar a toxicidade reprodutiva da ayahuasca em ratos Wistar machos após exposição crônica em doses usuais e elevadas, e os efeitos neurocomportamentais desta exposição. 


\section{REVISÃo BIBLIOGRÁFICA}

\subsection{Origem da ayahuasca e seu consumo no contexto religioso}

A ayahuasca, que na língua quéchua significa "videira das almas", é uma cocção vegetal com potencial alucinógeno, preparada e tomada por povos indígenas da Amazônia desde tempos imemoráveis. É formada pela mistura da folha do arbusto chacrona, Psychotria viridis, e do cipó mariri, Banisteriopsis caapi, ambas nativas da Amazônia. Descobertas arqueológicas feitas na bacia Amazônica sugerem que seu uso data da pré-história (Naranjo, 1986). Ela é conhecida por uma variedade de outros nomes incluindo hoasca, yajé, natena, caapi, daime e vegetal (Grob et al., 1996).

Cerca de 70 tribos indígenas da Amazônia utilizam essa bebida em rituais xamânicos e religiosos, incluindo os Yaminawa, Kaxinawá, Ashaninka, Sharanauwa, Baranara e Airo-pai (Costa et al., 2005). Para os xamãs, a ayahuasca é considerada uma ferramenta de diagnóstico e cura além de ser uma via de acesso aos reinos sobrenaturais (Grob et al., 1996; Tupper, 2008).

Considerada sagrada, a ayahuasca foi incorporada em rituais de religiões ayahuasqueiras com influência do espiritismo, liturgia cristã e catolicismo popular (Labate et al., 2010; Macrae, 2004; Tupper, 2008). O Santo Daime foi fundado em 1930 em Rio Branco (Acre) pelo ex-seringueiro Raimundo Irineu Serra, conhecido como Mestre Irineu, o curador. A palavra daime deriva da expressão "Dai-me força", "Dai-me luz". Nessa comunidade religiosa a ayahuasca é conhecida como daime ou chá do Santo Daime e os rituais envolvem a preparação do chá associado ao canto de hinos e bailados por membros da igreja (Labate \& Araújo, 2002). A doutrina daimista incorporou em seu processo de formação elementos do espiritismo kardecista, do xamanismo amazônico além de aspectos das religiões afro-brasileiras e do cristianismo (Ferreira, 2008).

A Barquinha, fundada em 1940 em Rio Branco por Daniel Pereira de Mattos, possui elementos afro-brasileiros com forte influência da umbanda sendo uma de suas características a remoção de espíritos malignos e o combate à feitiçaria (Macrae, 2004). Possui também influencia do cristianismo e catolicismo popular e 
elementos xamânicos, com atividades dirigidas a cura de doenças físicas e psíquicas (Pires et al, 2010).

O Centro Espírita Beneficente União do Vegetal (UDV) foi fundada em Porto Velho (RO) em 1961 pelo ex-seringueiro José Gabriel da Costa, conhecido como Mestre Gabriel. A doutrina da UDV é fundamentada na existência do espírito, que evolui ao longo de sucessivas reencarnações. O conjunto doutrinário da UDV é formado por ensinos, chamadas (cânticos), histórias e explicações ligadas a Jesus, personagens bíblicos e as entidades lansã e Janaína, entre outras, que são dadas aos seguidores para aprimoramento das suas virtudes morais e intelectuais (http://udv.org.br/\#after_full_slider_1).

As três religiões ayahuasqueiras são marcadas por um polimorfismo religioso profundo e pelo veículo singular e especial que é a bebida sagrada, possibilitando um desenvolvimento espiritual e um auto-conhecimento (Ferreira, 2008). O preparo do chá pelas comunidades religiosas varia conforme o tempo de fervura do mariri e chacrona e das quantidades utilizadas. Em geral, as sessões religiosas ocorrem a cada duas semanas e geralmente no período noturno. Os líderes religiosos servem um pequeno copo de chá de forma ritualizada aos outros membros e as sessões são projetadas para durarem cerca de quatro horas, que é o tempo de duração dos efeitos psicoativos da ayahuasca (Anderson et al., 2012). Esses efeitos podem incluir sensações de introspecção, uma intensificação geral das emoções e uma proximidade íntima com Deus ou outros seres espirituais (Anderson et al, 2012). Os efeitos somáticos podem incluir tonturas, vômitos e diarreia, sensações estas caracterizadas como a "peia" pelas comunidades religiosas, sendo considerada benéfica e purificadora dos aspectos físicos, morais e espirituais do indivíduo (Silva, 2004; Tupper, 2008).

Atualmente o consumo da ayahuasca tem alcance mundial graças aos três principais grupos religiosos, existindo representantes na Europa, Ásia, América do Sul e América do Norte (Halpern, 2004; Tupper, 2008; Martinez et al., 2009; Pires et al., 2010). Em muitos países como Espanha e Itália, os grupos religiosos lutam pela legitimação do uso sacramental da ayahuasca, e a liberdade religiosa foi concedida nos EUA, Holanda e Canadá (Tupper, 2008; Labate \& Feeney, 2012). No Brasil, o processo de legalização do uso ritualístico da ayahuasca teve início em 1986 pelo 
Conselho Federal de Entorpecentes (CONFEN, 1986), que retirou provisoriamente as plantas utilizadas na preparação da ayahuasca da lista de produtos proscritos pela Dimed (Divisão Médica do CONFEN), baseado em evidencias de que a ayahuasca não provoca prejuízos sociais. Em 1992, o Conselho, em sua $5^{a}$ reunião ordinária, autorizou definitivamente a bebida para fins religiosos em todo o Brasil. Em 2004, o Conselho Nacional Anti-Drogas (CONAD, 2004) reconheceu a legitimidade do uso religioso da ayahuasca, considerando que o uso por crianças deve permanecer sob a responsabilidade dos pais, e a utilização por mulheres grávidas é de responsabilidade destas, atendendo sempre a preservação do desenvolvimento do nascituro. Essas considerações foram reafirmadas pela Resolução № 1 do CONAD de 25 de janeiro de 2010 que também propôs a elaboração de um Cadastro Nacional de Entidades Usuárias da Ayahuasca (CNEA), de caráter facultativo.

Embora a legislação vigente sobre a ayahuasca proíba a sua comercialização, a aquisição da bebida é de fácil acesso na internet em pacotes turísticos na Amazônia, principalmente. Alguns sites oferecem plantas análogas às utilizadas na preparação da ayahuasca e garantem ter os mesmos princípios ativos, incluindo a Diplopterys cabrerana e 0 B. inebrians (http://www.naturezadivina.com.br/loja/index.php?cPath= 48_34). Também são encontrados produtos sintéticos denominados "farmahuasca", que são cápsulas contendo componentes químicos da ayahuasca, principalmente o DMT, ou outras combinações, podendo apresentar efeitos psicoativos similares (Ott, 1999).

\subsection{Espécies botânicas e composição química da ayahuasca}

\subsubsection{Banisteriopsis caapi}

A Banisteriopsis caapi (Figura 1), componente utilizado na preparação da ayahuasca, é uma espécie de cipó pertencente à família Malpiguiaceae. Existem outras espécies que são utilizadas em menor escala na preparação da bebida como a B. longialata, B. lútea, B. martiniana e B.muricata (Schultes, 1982). A B. caapi, 
também conhecida como Mariri ou Jagube, é nativa da Amazônia ocorrendo também no Peru, Colômbia, Equador e Bolívia.

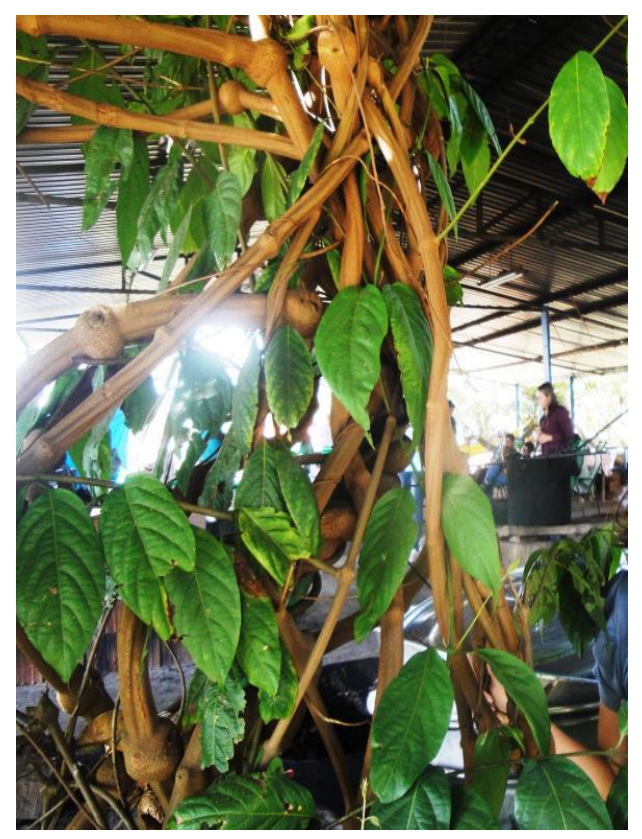

Figura 1. Banisteriopsis caapi. Fonte: Foto tirada no Núcleo Luz do Oriente (UDV), Brazlândia-DF.

O caule do cipó mariri contém os alcaloides $\beta$-carbolinas harmina (HRM), harmalina (HRL) e tetrahidro-harmina (THH) (Figura 2), que são inibidores reversíveis da enzima mitocondrial monoamina oxidase (MAO) (McKenna, 1984; Harvey \& Champe, 1998). Essa enzima é responsável pela degradação da serotonina, dopamina e noradrenalina por meio da desaminação e ocorre em dois subtipos (MAO-A e MAO-B). A inibição da MAO-A provoca o aumento dos níveis de serotonina (Gareri et al.,1998).

As $\beta$-carbolinas também possuem potencial alucinógeno em doses de 300 a $500 \mathrm{mg}$ para harmalina e tetrahidroharmina e $100 \mathrm{mg}$ para harmina (Brito, 2004). As concentrações desses compostos na planta variam de $0,05 \%$ a 1,95\% de peso seco, e na ayahuasca pode variar dependendo do método e da quantidade utilizada para 0 preparo (McKenna, 2004). Em uma dose usual de ayahuasca as quantidades de $\beta$ carbolinas estão abaixo do limiar para atividade alucinógena, mas acima para atividade inibitória da MAO (Brito, 2004). 
Como inibidores da MAO, os alcaloides aumentam os níveis de serotonina no cérebro e podem produzir efeitos sedativos em altas doses. A THH não é um forte inibidor da enzima, mas atua na inibição da recaptação de serotonina resultando em níveis mais elevados desse neurotransmissor na fenda sináptica (Callaway et al., 1999; McKenna, 2004).<smiles>COc1ccc2c(c1)[nH]c1c(C)nccc12</smiles>

Harmina (HRM)<smiles>COc1ccc2c3c([nH]c2c1)[C@H](C)NCC3</smiles>

Harmalina (HRL)

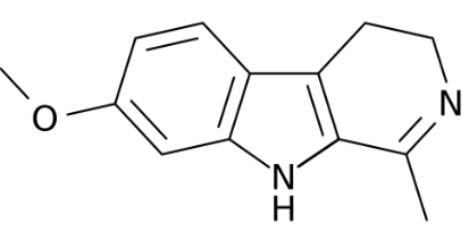

Tetrahidro-harmina $(\mathrm{THH})$<smiles>NCCc1c[nH]c2ccc(O)cc12</smiles>

Serotonina (5-hidroxitriptamina ou 5-HT)

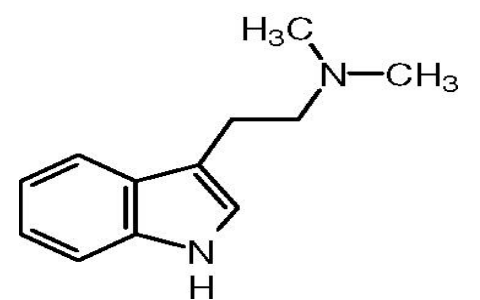

$\mathrm{N}, \mathrm{N}$-dimetiltriptamina (DMT)

Figura 2. Estrutura molecular dos alcaloides $\beta$-carbolínicos, $N, N$ - dimetiltriptamina (DMT) e serotonina (5HT).

\subsubsection{Psychotria viridis}

A outra espécie vegetal mais comumente utilizada na preparação da ayahuasca é a Psychotria viridis (Figura 3) pertencente à família Rubiaceae e popularmente conhecida como chacrona ou rainha. Trata-se de um arbusto nativo da Amazônia e com distribuição em diversas regiões do Brasil e do mundo (Quinteiro et al, 2006). 


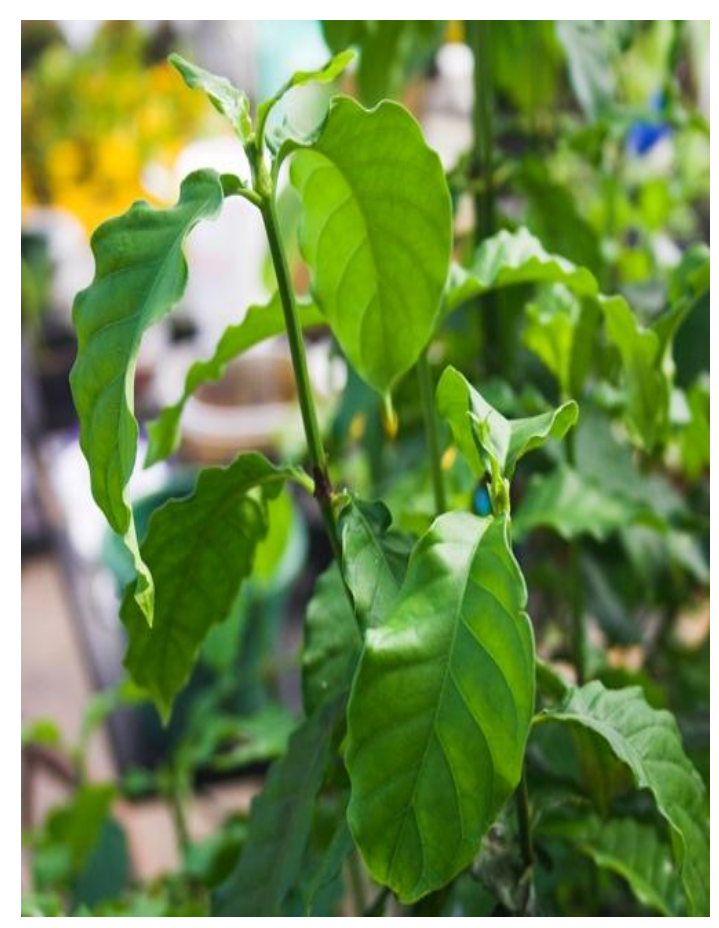

Figura 3. Psychotria viridis. Fonte: www.botanicalspirit.com

A folha do arbusto chacrona contém o agente psicotrópico $\mathrm{N}, \mathrm{N}-$ dimetiltriptamina (DMT, Figura 2), em concentrações que variam de $0,1 \%$ a $0,66 \%$ de peso seco (McKenna, 2004). Essa molécula também é encontrada em outras plantas e em animais, incluindo o homem (Ott, 1994; Callaway et al., 1996). Quando administrado por via parentérica, o DMT age no cérebro durante um curto período de tempo, e por via oral sofre uma rápida degradação pela MAO presente no fígado e intestino, não atingindo o sistema nervoso (Buckholtz \& Boggan, 1977; Callaway, 1996).

Devido a sua similaridade estrutural com a serotonina (5-hidroxitriptamina ou $5 \mathrm{HT}$ ) (Figura 2), o DMT se liga aos receptores serotoninérgicos no cérebro, principalmente os do tipo $5-\mathrm{HT}_{2 \mathrm{~A}}$, proporcionando assim seu efeito alucinógeno (Halberstadt, 2015; Smith et al., 1998). A comercialização e uso do DMT é proibido no Brasil (Portaria $n^{\circ} 344,1998$ ) e internacionalmente pela Convenção das Nações Unidas sobre Substâncias Psicotrópicas (Convention on Psychotropic Substance, 1971). 


\subsection{Farmacologia dos componentes da ayahuasca}

Os efeitos psicoativos da ayahuasca ocorrem devido à ação sinérgica entre seus componentes, as $\beta$-carbolinas e o DMT. Os alcaloides $\beta$-carbolínicos, principalmente harmina e harmalina inibem reversivelmente a MAO-A, o que impede a degradação do DMT quando ingerido pela via oral e consequentemente permite a sua chegada e ação no cérebro. Na ausência das $\beta$-carbolinas, o DMT é rapidamente oxidado pela $\mathrm{MAO}$ e por essa razão é oralmente inativo quando ingerido.

A principal via de degradação das monoaminas serotonina (5HT), dopamina (DA) e norepinefrina (NE) ocorre pela desaminação oxidativa catalisada pela MAO. Os inibidores da monoamina oxidase (IMAO) são classificados de acordo com sua especificidade para as isoenzimas MAO-A e MAO-B e são importantes na modulação da neurotransmissão serotoninérgica. A inibição da degradação das monoaminas pelos IMAO implica no aumento dos neurotransmissores 5HT e NE no citoplasma dos neurônios pré-sinápticos, e leva a um aumento na captação e no armazenamento desses neurotransmissores nas vesículas sinápticas, bem como seu extravasamento na fenda sináptica (Golan, 2009). Como IMAO, os alcaloides $\beta$ carbolínicos, além de protegerem o DMT da sua degradação pela MAO intestinal e hepática, atuam aumentando os níveis de neurotransmissores nos terminais nervosos (Callaway et al., 1999).

A $5 \mathrm{HT}$, principal neurotransmissor envolvido na farmacologia da ayahuasca, é produzida a partir do aminoácido triptofano em duas reações catalisadas pela triptofano hidroxilase (TPH) e L-aminoácido aromático descarboxilase (Figura 4). A 5HT recém-sintetizada é concentrada e estocada em vesículas sinápticas, localizadas em todo o neurônio, através do transportador de monoaminas vesicular (VMAT). O potencial de ação no neurônio pré-sináptico produz a fusão das vesículas com a membrana celular através de um processo dependente de $\mathrm{Ca}^{2+}$, resultando na neurotrasmissão. O transportador seletivo de 5HT (SERT) remove 0 neurotransmissor da fenda sináptica e após atingir o interior da célula ele pode ser novamente estocado em vesículas ou sofrer degradação pela MAO mitocondrial. Concentrações aumentadas de serotonina na fenda sináptica estimulam os auto- 
receptores $5 \mathrm{HT}_{1 \mathrm{D}}$, provocando assim uma inibição da síntese e liberação por retroalimentação (Figura 4) (Golan, 2009).

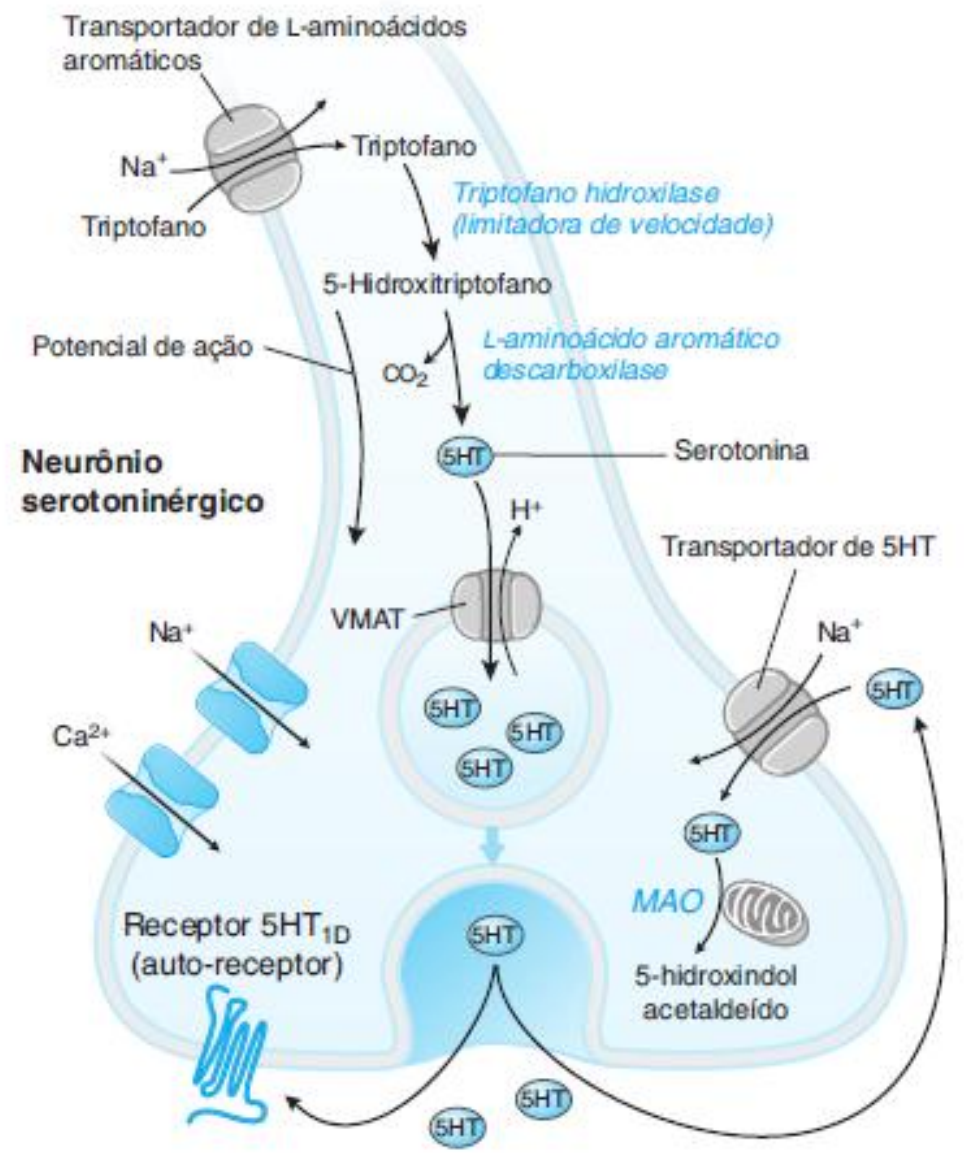

Figura 4. Regulação pré-sináptica da neurotransmissão da 5HT. Fonte: Golan, 2009, p.188.

Existem sete classes e 14 subtipos de receptores serotoninérgicos expressos de forma diferenciada no cérebro (5- $\mathrm{HT}_{1 \mathrm{~A}-\mathrm{F}}, 5-\mathrm{HT}_{2 \mathrm{~A}-\mathrm{C}}, 5-\mathrm{HT}_{3}, 5-\mathrm{HT}_{4}, 5-\mathrm{HT}_{5 \mathrm{~A}-\mathrm{B}} 5-\mathrm{HT}_{6} \mathrm{e}$ 5- $\mathrm{HT}_{7}$ ) (Fantegrossi et al., 2008; Golan, 2009). Os receptores 5- $\mathrm{HT}_{1 \mathrm{~A}}$ são expressos nos neurônios do núcleo da rafe, amídala e hipocampo e provavelmente estão envolvidos na ação central da ayahuasca, assim como os receptores $5-\mathrm{HT}_{2 \mathrm{~A}}$ amplamente distribuídos nos tecidos periféricos e áreas do córtex (Halberstadt, 2015; Mckenna et al., 1990).

A 5HT está envolvida em inúmeros processos importantes do corpo, tais como regulação no ciclo de sono-vigília, na função neuroendócrina, na percepção da dor, na modulação do humor e na motivação. Áreas diferentes do cérebro controlam 
essas funções, na medula espinhal as projeções serotoninérgicas estão envolvidas no controle motor, na percepção da dor e na regulação visceral. No encéfalo frontal, a 5HT é importante na função endócrina, na modulação do humor e na cognição. Condições patológicas tais como a depressão, na qual é caracterizada por uma desregulação do humor, provavelmente envolvem o sistema central da $5 \mathrm{HT}$, bem como da NE (Golan, 2009).

O DMT é um alucinógeno pertencente à classe das indolaminas que incluem também a dietilamida do ácido lisérgico (LSD) e está classificado no grupo das indolalquilaminas, que incluem o N,N-dipropiltriptamina (DPT), o 5-metoxi-DMT (5Meo-DMT), a psilocibina (4-fosforiloxi-DMT) e seu metabólito ativo desfosforilado psilocina (4-hidroxi-DMT) (Figura 5). A psilocibina e seu metabólito são encontrados em cogumelos alucinógenos do gênero Psilocybe (Halberstadt, 2015). As indolalquilaminas se ligam de forma não seletiva aos receptores $5-\mathrm{HT}$ e certos alucinógenos desse grupo, principalmente o DMT e seus derivados, também agem como um substrato para o SERT e VMAT (Nagai et al., 2007; Cozzi et al., 2009; Halberstadt, 2015). Além disso, o DMT também possui afinidade pelo receptor do tipo Sigma-1 ( $\sigma 1)$, uma proteína chaperona localizada nas mitocôndrias associadas a membrana do retículo endoplasmático e amplamente distribuída no sistema nervoso central e periférico (Cozzi et al., 2009; Fontanilla et al., 2009; Halberstadt, 2015). A ativação desse receptor leva a uma reestruturação celular e promove a regulação da transmissão sináptica pela modulação da mobilização intracelular de $\mathrm{Ca}^{2+}$ (Corregiari, 2009). O DMT endógeno se liga ao receptor $\sigma 1$ quando presente em baixas concentrações, e em altas concentrações, mobiliza esse receptor da membrana do retículo endoplasmático para a membrana da célula e inibe os canais de sódio (Cozzi et al, 2009). A ligação do DMT com o receptor $\sigma 1$ e a SERT é bem menos potente comparada com à ligação nos receptores $5-\mathrm{HT}_{1 \mathrm{~A}}$ e $5-\mathrm{HT}_{2 \mathrm{~A}}$ (Halberstadt, 2015). 


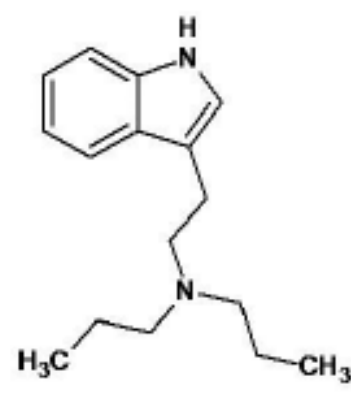

DPT<smiles>[R]Oc1cccc2[nH]cc(CCN(C)C)c12</smiles>

$\mathrm{R}=\mathrm{H} ;$ Psilocin

$\mathrm{R}=\mathrm{PO}_{3} \mathrm{H}_{2} ;$ Psilocybin<smiles>CN(C)CCc1c[nH]c2ccccc12</smiles>

DMT<smiles>COc1ccc2c(CCN(C)C)c[nH]c2c1</smiles>

5MeO-DMT<smiles>CCN(CC)C(=O)[C@@H]1C=C2c3cccc4[nH]cc(c34)C[C@H]2N(C)C1</smiles>

LSD

Figura 5. Estrutura química dos alucinógenos indoleaminas (LSD) e indolalquilaminas (DPT, DMT, 5Meo-DMT, psilocibina e psilocina).

Existe um mecanismo de duas etapas que permite a chegada de altas concentrações de DMT nos neurônios. Esse processo envolve sua captação na membrana plasmática via SERT seguido do transporte e armazenamento em vesículas sinápticas via VMAT (Cozzi et al, 2009). O SERT é um transportador seletivo, presente na membrana neuronal, responsável pela recaptação da serotonina da fenda sináptica de volta ao neurônio pré-sináptico (Golan, 2009). Ao agir como um substrato para o transportador SERT, o DMT compete com a serotonina inibindo sua recaptação, dessa forma ele também atua aumentando os níveis desse neurotransmissor na fenda sináptica (Cozzi et al, 2009). Após alcançar o interior da célula o DMT pode interagir com receptores $\sigma 1$ intracelulares ou ser estocado em vesículas sinápticas pela VMAT. A fusão das vesículas com a membrana celular libera o DMT na fenda sináptica. A partir de então, a molécula pode interagir com receptores serotoninérgicos, bem como receptores $\sigma 1$ presentes na superfície celular ou outros alvos moleculares. Os efeitos alucinógenos dos 
compostos triptaminícos, como o DMT, provavelmente ocorrem devido à interação complexa entre todos esses mecanismos (Cozzi et al, 2009).

\subsection{Efeitos biológicos e psíquicos da ayahuasca}

Os efeitos fisiológicos da ingestão da ayahuasca são caracterizados por náuseas, vômitos, diarreia, tremores, tonturas, taquicardia, midríase e hipertensão (Callaway and Grob, 1998; Vives et al., 2012). No sistema cardiovascular ocorre principalmente vasoconstrição e contração do músculo liso (Costa et al, 2005).

Os efeitos psíquicos da ayahuasca estão relacionados com alterações do estado afetivo e emocional. Também são observadas alterações no pensamento e na memória, hiper-sugestibilidade, despersonalização, apatia, medo, insônia e sensações de morte iminente em alguns casos. No plano perceptivo-sensorial, com os olhos fechados, observam-se distorções do espaço e tempo, modificação das sensações corporais, alterações nas percepções de forma, cores e sons. Além de sinestesias e alucinações com alteração dos sentidos visual, olfativo e auditivo (Shanon, 2003; Pires et al., 2010).

A alucinação conhecida como "miração" é uma manifestação específica caracterizada por visões de acordo com a experiência individual, podendo ocorrer sensações de voo, substituição do corpo por outro ser, visões de animais, divindades, dentre outros (Cazenave, 2000). Além disso, a ayahuasca pode provocar os chamados "estados alterados de consciência" que são caracterizados por alterações da cognição, percepção e volição (Costa et al., 2005).

\subsection{Potencial terapêutico da ayahuasca}

Evidências anedóticas e estudos conduzidos com usuários regulares no contexto religioso demonstram possíveis aplicações terapêuticas da ayahuasca no tratamento do alcoolismo e abuso de outras substancias psicoativas, bem como no tratamento da defasagem serotoninérgica (McKenna, 2004). Grob et al. (1996), após avaliações psiquiátricas realizadas em usuários frequentes da UDV $(n=30)$, 
verificaram ausência ou diminuição de reações de agressão, raiva, ressentimento, ansiedade e alienação, quando comparado ao grupo controle (não usuários). Além disso, indivíduos que faziam anteriormente uso do álcool se abstiveram completamente após iniciarem o uso da ayahuasca.

Outro indício do potencial terapêutico da ayahuasca é a possibilidade de regulação dos níveis de serotonina em condições de déficit em longo prazo. O uso regular da ayahuasca, aparentemente, resulta em modificação da modulação serotoninérgica com aumento da densidade de transportadores de serotonina no cérebro (McKenna, 2004). Vários fármacos da classe dos ISRS agem diretamente nesses transportadores que estão intimamente envolvidos em transtornos afetivos como a depressão e outras desordens de humor. Há a hipótese de que as mudanças positivas de comportamento, relatadas por usuários da ayahuasca, estejam relacionadas com a elevação da quantidade de transportadores de serotonina que pode ocorrer com o uso crônico dessa infusão (Callaway et al., 1994).

Estudos em roedores demonstraram que a administração aguda e crônica de harmina, $\beta$-carbolina presente em maior concentração na ayahuasca, produziu efeito antidepressivo evidenciado pela diminuição do tempo de imobilidade e aumento da natação e climbing no teste de natação forçada. Além disso, foi observado um aumento nos níveis de fator neurotrófico derivado do cérebro (BDNF) no hipocampo dos animais tratados com harmina (Fortunato et al., 2009; Fortunato et al., 2010). O BDNF é uma proteína responsável por influenciar na sobrevivência e função de neurônios maduros, sua expressão no hipocampo é regulada negativamente por exposição ao estresse, podendo acarretar na atrofia de neurônios e diminuição da neurogênese. Esse quadro pode ser observado em pacientes com depressão e a administração de drogas antidepressivas tem mostrado eficiência no aumento da expressão de BDNF no hipocampo e córtex pré-frontal, promovendo dessa forma a neurogênese (Ayflegül et al., 2002). Estudo conduzido por nosso grupo (Pic-Taylor et al., 2015) demonstrou que ratos expostos a dose única de ayahuasca (15X e 30X a dose usada em um ritual religioso da UDV) tiveram diminuição da imobilidade e um aumento da natação no teste de natação forçada, comparado ao grupo controle e a animas expostos à fluoxetina, indicando um potencial efeito antidepressivo. 
Outro indício do potencial terapêutico da ayahuasca bastante intrigante é a possibilidade de produção de efeitos imunomoduladores significativos. Essa evidência surgiu de relatos de usuários da América do Norte que afirmaram ter remissão de câncer e outras doenças graves após o uso regular da ayahuasca (Topping, 1998). Além disso, as características de acuidade mental, força física e longevidade em xamãs ayahuasqueiros podem ser resultado de suas excelentes funções imune providas de anos de trabalho com ayahuasca (McKenna, 2004). Essas evidências até o momento são apenas especulativas, no entanto algumas plantas com propriedades alucinógenas como a Lophophora williamsii (peiote) possuem potencial imune e antitumoral in vitro (Franco et al., 2003). As prováveis propriedades antitumorais da ayahuasca podem estar relacionadas em parte ao estimulo de quantidades altas de DMT nos receptores sigma 1. Esse estímulo transloca os receptores presentes na mitocôndria para a membrana da célula, podendo exercer efeito inibitório em muitos canais iônicos, como os canais de $\mathrm{Na}^{+} \mathrm{e}$ $\mathrm{Cl}^{-}$. Tendo em vista que os canais de $\mathrm{Cl}^{-}$participam da modulação do ciclo celular, essa interação pode ter implicações importantes para o câncer. O estimulo de quantidades endógenas de DMT nos receptores sigma 1 promovem um influxo de $\mathrm{Ca}^{+}$nas mitocôndrias, sendo importante para a redução da glicólise excessiva e fosforilação oxidativa mitocondrial. Há a hipótese de que a combinação sinérgica entre as $\beta$-carbolinas e o DMT promova a diminuição do fornecimento de sangue para o tumor, ativação de mecanismos apoptóticos normais e diminuição da proliferação celular (Schenberg, 2013).

\subsection{Toxicidade da ayahuasca}

\subsubsection{Toxicidade aguda}

O interesse pelos efeitos agudos da ayahuasca se torna importante para estabelecer um nível de segurança de consumo pelos usuários no contexto religioso. Existe uma quantidade limitada de trabalhos científicos sobre a toxicidade oral do DMT, a maioria dos estudos referentes à ayahuasca envolvem descrições etnográficas, ensaios neurológicos ou potencial uso medicinal (Gable, 2007). 
O critério padrão para acessar a toxicidade aguda de determinada substância tem sido a identificação da sua dose letal. A dose letal média ( $\left(L_{50}\right)$ é a quantidade de determinada substância que causa a mortalidade de $50 \%$ dos animais da população experimental, em uma única exposição. É reportado que a $\mathrm{DL}_{50}$ do DMT em camundongos seja em torno de $47 \mathrm{mg} / \mathrm{kg}$ pc por via intraperitoneal e $32 \mathrm{mg} / \mathrm{kg}$ pc por via intravenosa (Gable, 2007). A partir destes valores, e assumindo que o homem seja 20X mais sensível que roedores, o autor estimou uma $\mathrm{DL}_{50}$ intravenosa de DMT de 1,6 mg/kg pc em humanos. Considerando que a biodisponibilidade oral de uma substancia seja cinco vezes menor comparado com a sua biodisponibilidade intravenosa, o autor estimou também que a $\mathrm{DL}_{50}$ oral do DMT seja de $8 \mathrm{mg} / \mathrm{kg}$ pc, maior que 20X a dose utilizada em uma cerimônia religiosa (Gable, 2007).

Estudo realizado por nosso grupo de pesquisa com o objetivo de determinar a toxicidade oral aguda da ayahuasca em ratas fêmeas Wistar, identificou que a $\mathrm{DL}_{50}$ de uma infusão de ayahuasca cedida pela UDV foi acima de 50X a dose usada em um ritual religioso (Pic-Taylor et al., 2015). O mesmo estudo avaliou a neurotoxicidade da ayahuasca em regiões do cérebro ricas em receptores serotoninérgicos como amídala, núcleo da rafe e hipocampo. Foi identificada uma forte atividade neuronal, evidenciada pela marcação de neurônios reativos a c-fos nos animais expostos a ayahuasca em uma dose única correspondente a 30X a dose usual. A quantificação da densidade neuronal pela coloração de Nissl não indicou danos cerebrais que resultasse em alteração na morfologia e quantidade celular (Pic-Taylor et al., 2015). Estudo realizado por Corrêa et al., (2014), com o objetivo de quantificar os corpos celulares de neurônios em camundongos expostos a ayahuasca, mostrou que uma exposição única de $30 \mathrm{mg} / \mathrm{mL}$ via intraperitoneal, não causou alteração quantitativa de neurônios no córtex cerebral. Brito et al., (1994) concluiu que uma administração única de $500 \mathrm{mg} / \mathrm{kg}$ pc em ratos não produziu dano neurológico.

Estudo conduzido por Melo Junior (2014), com o objetivo de avaliar o potencial citotóxico e genotóxico da ayahuasca após exposição única em ratos Wistar mostrou que as doses administradas de $1 \mathrm{X}$ e $5 \mathrm{X}$ não provocaram citotoxicidade ou danos no DNA. Porém os animais tratados com a dose de 15X apresentaram um aumento na incidência de micronúcleos, indicando danos citogenéticos. 
$\mathrm{Na}$ literatura é relatado somente um caso de intoxicação letal por suposta ingestão única de ayahuasca com fins recreativos, no qual exames toxicológicos no sangue detectaram a presença de tetrahidroharmina $(0,38 \mathrm{mg} / \mathrm{L})$, harmalina $(0,07$ $\mathrm{mg} / \mathrm{L})$, harmina $(0,17 \mathrm{mg} / \mathrm{L})$, DMT $(0,02 \mathrm{mg} / \mathrm{L})$ e 5-MeO-DMT $(1,88 \mathrm{mg} / \mathrm{L})$ (Sklerov et al., 2005). Esse caso foi contestado posteriormente por Callaway et al., (2006), que afirmaram que nenhuma infusão vegetal utilizada por tribos indígenas em cultos religiosos concentraria níveis de triptaminas a ponto de ser letal para o ser humano.

Inibidores da MAO, como as $\beta$-carbolinas presentes na ayahuasca, quando combinado com medicamentos antidepressivos da classe de inibidores seletivos de recaptação de serotonina (ISRS), podem causar reações adversas e até fatais. $O$ bloqueio da MAO associado à inibição da recaptação de serotonina pelos ISRS pode levar ao quadro de síndrome serotoninérgica, no qual é evidenciado um acúmulo excessivo nos níveis de serotonina na fenda sináptica (Callaway et al., 1996). Esse quadro se caracteriza por uma série de efeitos adversos, dentre eles, diarreia, tremores, hipertemia, sudorese, espasmos musculares, instabilidade autonômica e possivelmente morte (Pires et al., 2010).

Existem casos de morte de pessoas que usam alucinógenos triptaminas para fins recreativos em que a causa não é por dosagem incorreta ou overdose, mas sim por mudanças no estado de consciência que levam ao surto de comportamentos irracionais (Tittarelli et al., 2015). No contexto religioso não existem relatos de morte entre os usuários dessa infusão.

\subsubsection{Toxicidade crônica}

Em estudo realizado com voluntários que utilizaram ayahuasca durante as cerimônias religiosas não foi constatado a ocorrência de efeitos adversos graves na saúde desses indivíduos. Em usuários de longo prazo, uma avaliação psicológica demonstrou que as funções cognitivas tais como a habilidade matemática e fluência verbal não foram alteradas (Grob et al., 1996).

Callaway et al, (1994) observaram que o uso regular da ayahuasca pode desencadear o desenvolvimento de alguma tolerância, podendo haver alterações nos níveis de serotonina e outros neurotransmissores. No entanto, não existem estudos conclusivos até o momento que demonstrem que o consumo crônico de 
ayahuasca provoque dependência (Pires et al., 2010). Segundo Gable, (2007), o potencial de dependência oral do DMT é mínimo.

Estudo realizado por nosso grupo de pesquisa com o objetivo de avaliar a toxicidade crônica da ayahuasca administrada durante 15 dias consecutivos em ratas prenhes mostrou que $48 \%$ dos animais tratados com $4 \mathrm{X}$ e $8 \mathrm{X}$ a dose usual foram a óbito, após $96 \mathrm{~h}$ e $48 \mathrm{~h}$ do início do tratamento, respectivamente (da Motta, 2013). No mesmo estudo foi identificado um aumento do peso do estômago nos animais tratados com as doses de $1 \mathrm{X}, 2 \mathrm{X}$ e $8 \mathrm{X}$, bem como uma dilatação do estômago e intestino nos animais tratados com a maior dose (8X). Além disso, foram verificadas alterações histopatológicas significativas no baço, fígado e rins dos animais tratados, embora tenham sido consideradas de grau leve (Morais, 2014). Este estudo sugere que a ayahuasca possui um potencial neurotóxico importante quando administrada cronicamente em doses altas, evidenciado também por uma diminuição significativa da densidade neuronal em regiões do hipocampo e núcleo da rafe (Morais, 2014). Outro estudo de neurotoxicidade conduzido com ratos Wistar, mostrou que os animais tratados com ayahuasca diluída em $50 \%$ durante 21 dias obtiveram uma quantidade maior de células neuronais apoptóticas, analisadas pelo ensaio de TUNEL (Terminal deoxynucleotidyl transferase dUTP Nick End Labeling) (Figueroa, 2012). Este ensaio identifica danos no material genético baseado na detecção de fragmentos de DNA, que pode ser resultado do processo apoptótico, porém esta via de morte celular precisa ser confirmada por outros métodos (Lozano et al., 2009).

Santos et al., (2013) verificou um aumento significativo nos níveis de TGO (transaminase glutâmica oxalacética) em animais tratados com ayahuasca cronicamente em dose usual diária (100 ml/kg pc), demonstrando haver algum grau de comprometimento da função hepática desses animais. Figueroa (2012) identificou níveis mais altos de ureia nos animais após tratamento crônico com ayahuasca diluída em $50 \%$, sugerindo haver um indicativo de dano renal. Além disso, os animais tratados com ayahuasca obtiveram níveis menores de vitamina $\mathrm{E}$, indicando a ocorrência de estresse oxidativo que poderia indiretamente desencadear um processo apoptótico celular. 


\subsubsection{Toxicidade reprodutiva}

A toxicidade reprodutiva é a ocorrência de efeitos adversos biológicos no sistema reprodutivo de fêmeas ou machos que podem ser resultado da exposição a agentes ambientais (EPA, 1996). Ela pode ser expressa como alterações nos órgãos reprodutivos, no sistema endócrino ou na fertilidade e podem se manifestar na produção e transporte de gametas, no comportamento sexual, na fertilidade, gestação, parto, lactação e desenvolvimento do nascituro além de outras funções que são dependentes do sistema reprodutivo.

Desordens na capacidade reprodutiva associada a produtos químicos ambientais, nutrição, estilo de vida e estresse estão se tornando proeminentes na saúde pública. Em humanos, os transtornos na reprodução podem incluir doenças genéticas que afetam ou comprometem o sistema reprodutivo, impotência, redução da fertilidade, aborto espontâneo, baixo peso do nascituro, entre outros. Agentes químicos ou físicos que são capazes de alterar a reprodução podem afetar os sistemas reprodutivos em qualquer momento do ciclo da vida, incluindo os períodos críticos do desenvolvimento, podendo alterar o desempenho reprodutivo bem após o tempo inicial de exposição (EPA, 1996).

Estudos em humanos são os mais adequados para acessar os riscos possíveis ao sistema reprodutivo, mas na ausência desses dados a compreensão dos mecanismos que controlam a reprodução pode surgir de estudos com animais de laboratório. A partir disso é possível estimar os riscos dos efeitos reprodutivos nos seres humanos, contudo algumas informações necessárias para tal extrapolação não são disponíveis (EPA, 1996). Existem muitas limitações na utilização dos modelos animais, pois as características específicas reprodutivas variam em cada espécie. Como exemplo, a produção espermática é maior em espécies de rato, coelho, cachorro e primata comparando com humanos, além disso, a porcentagem de espermatozoides progressivamente móveis e morfologicamente normais em humanos é inferior aos valores das outras espécies animais (Amann, 1982). Portanto o ser humano possui uma fertilidade relativamente mais baixa e pode estar mais suscetível aos riscos de tóxicos reprodutivos do que machos de outras espécies (Working, 1988). 
No contexto religioso, as gestantes podem fazer o uso da ayahuasca, cabendo a elas a responsabilidade de tal decisão (CONAD, 2010), e é comum o uso de pequenas quantidades como protetor e facilitador do parto. No estudo realizado por da Motta (2013) em ratas prenhes expostas a ayahuasca em doses de 1 a 8X a dose usual mostrou alterações nos índices reprodutivos, como diminuição no número de fetos, aumento no número de reabsorções e diminuição no peso corpóreo e no peso relativo dos órgãos dos fetos. Malformações viscerais dos fetos de ratas tratadas na maior dose também foram observadas.

Oliveira et al., (2010), não observaram sinais clínicos de toxicidade materna em ratas após administração crônica de ayahuasca com 5X e 10X a dose usual durante o período gestacional. Porém, foram identificadas malformações viscerais nos fetos dos animais tratados, como dilatação dos ventrículos laterais e terceiro do cérebro, e dilatação da pelve renal.

Em estudos com animais, a distinção entre o efeito direto e indireto de uma substancia sobre o embrião se torna difícil. Em muitos casos, a toxicidade durante 0 desenvolvimento fetal ocorre de forma secundária à toxicidade materna (Oliveira et al., 2010). Os estudos citados sobre o potencial toxicológico reprodutivo da ayahuasca em ratas prenhes demonstraram que a ação da ayahuasca sobre o desenvolvimento do embrião pode ocorrer de forma direta, ou seja, na ausência de toxicidade materna, bem como de forma indireta. Porém, é importante ressaltar que estes estudos foram conduzidos com doses muito maiores que a dose usual (até 10X), e exposição diária, enquanto o uso religioso dessa infusão ocorre geralmente uma vez a cada 15 dias. Portanto, os resultados obtidos não podem ser extrapolados para humanos de maneira direta, mas alertam para o uso abusivo e recreativo da ayahuasca, principalmente por gestantes.

Vários estudos mostram a relação entre drogas psicoativas com a infertilidade masculina. Testes em animais demonstraram que substâncias como o tetrahidrocanabinol (THC), encontrado em espécies vegetais do gênero Cannabis, reduzem os níveis de testosterona prejudicando a produção e motilidade espermática e consequentemente a fertilidade masculina (Morgan et al, 2011; Onyije, 2012). Drogas como o álcool, tabaco, cocaína e esteroides anabólicos androgênicos também são apontadas como prováveis agentes de infertilidade 
(Onyije, 2012; Axelsson et al, 2013; Vignera at al, 2013; Kulkarni et al, 2014). Contudo, nenhum estudo toxicológico foi ainda conduzido para avaliar os aspectos de toxicidade reprodutiva masculina em animais expostos à ayahuasca, objeto de estudo deste trabalho.

\subsection{Sistema reprodutor masculino}

A manutenção das características secundárias masculinas e a fertilidade são processos que dependem basicamente da função dos testículos, que é proporcionar a espermatogênese e síntese de hormônios sexuais. Durante a espermatogênese ocorrem inúmeras transformações que resultam na formação dos espermatozoides, que originam-se a partir da divisão meiótica das espermatogônias que formam espermatócitos primários e secundários, que por sua vez sofrem outra divisão meiótica para formarem as espermátides onde tem-se por meta inicial a redução do número cromossômico. A etapa final, denominada de espermiogênese, consiste na diferenciação da célula masculina, que adquire estruturas que serão importantes para a motilidade e interação com o ovócito. Nesta etapa de diferenciação, as espermátides passam de células redondas em espermatozoides (Figura 6), no qual ocorre a condensação do material genético, reposicionamento do núcleo da célula do centro para uma das extremidades, formação do acrossoma a partir do aparelho de Golgi e reposicionamento dos centríolos que participarão da formação do flagelo , além da formação da peça intermediária, que consiste num cordão de mitocôndrias organizadas, que irá gerar energia para o flagelo (Gilbert, 2003; Aires, 2008). Em um túbulo seminífero são encontradas espermatogônias, que fazem parte do estoque reserva, estas são células que se multiplicam por mitose e são extremamente resistentes à radiação e agentes tóxicos. Portanto, se um tratamento com um agente tóxico agride as células em proliferação, a espermatogênese pode ser restaurada após sua indução a partir do estoque reserva de espermatogônias (Amann, 1982). 


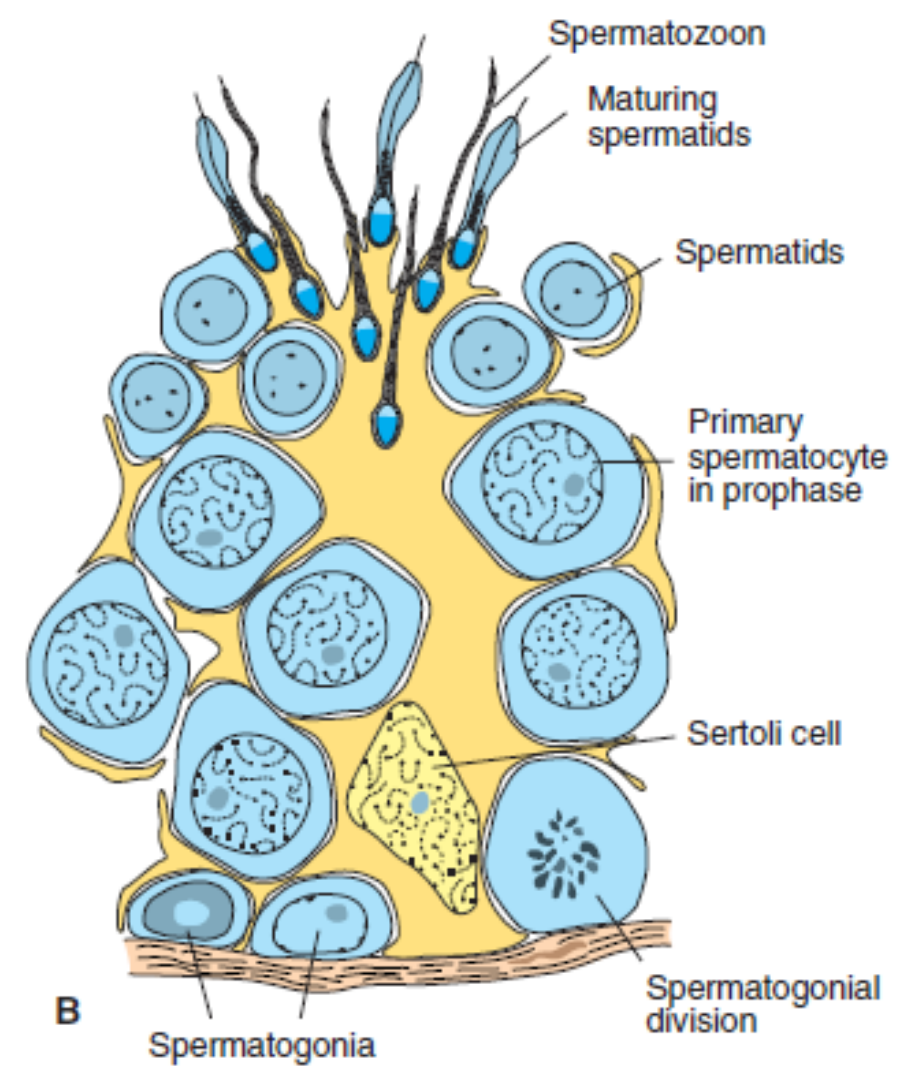

Figura 6. Seção de um túbulo seminífero mostrando a maturação celular e o progresso das células em direção ao lúmen dando origem aos espermatozoides. Fonte: Sadler, 2011, p. 24

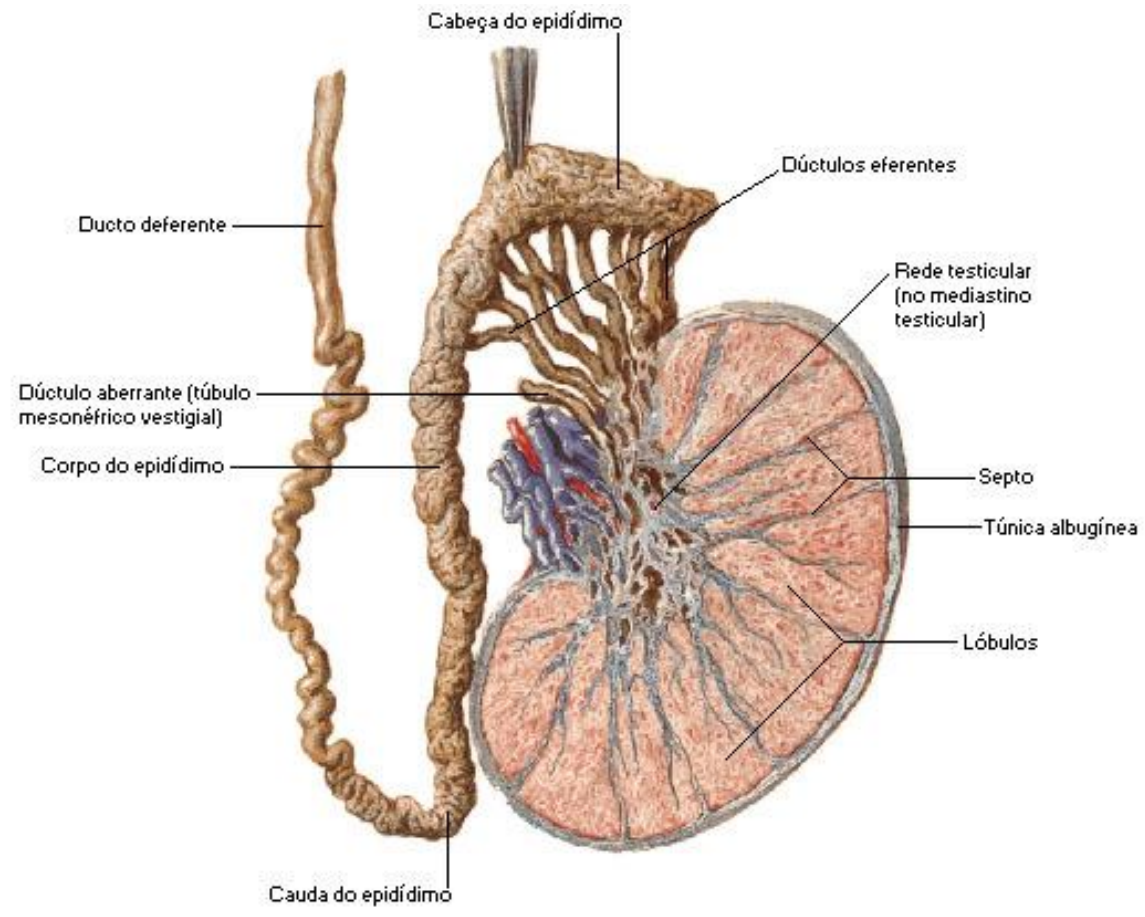

Figura 7. Testículo seccionado e sua conexão com o epidídimo. Fonte: Netter, 2000. 
Após o término da espermiogênese, os espermatozoides produzidos pelo testículo são liberados pelas células de Sertoli no lúmen (Figura 6) e entram no epidídimo via ductos eferentes (Figura 7). Durante o trajeto pelo epidídimo, estas células sofrem inúmeras alterações bioquímicas para tornarem-se espermatozoides maduros com capacidade fertilizante (O'Donnell et al, 2001), incluindo o desenvolvimento da motilidade progressiva, morfologia, propriedades bioquímicas e metabólicas (Fernandez et al, 2008; Orgebin-Crist, 1969). O tempo de trânsito do espermatozoide no epidídimo tem uma importância fundamental no processo de maturação, de modo que uma aceleração nesse tempo pode prejudicar a maturidade do espermatozoide e diminuir o número de gametas viáveis (Fernandez et al, 2008). Isso acontece porque o tempo disponível para os processos de maturação e aquisição da capacidade fértil é reduzido (Fernandez et al, 2008; Klinefelter \& Suarez, 1997). Após a passagem pelo epidídimo os espermatozoides são lançados nos ductos ejaculatórios e enriquecidos pelas secreções das vesículas seminais que contém principalmente frutose e prostaglandinas, constituindo o sêmen. Finalmente o sêmen é lançado na uretra prostática, nutrido com fluidos contendo zinco, ácido cítrico, espermina e fosfatase ácida (Aires, 2008).

Os androgênios são hormônios responsáveis por conferir as características secundárias masculinas e promover o amadurecimento sexual e a fertilidade. Eles são produzidos no testículo, pelas células de Leydig, e na adrenal a partir do colesterol. A testosterona é o androgênio mais abundante circulando em maior proporção acoplada à albumina ou à proteína ligadora de hormônios sexuais (SHBG), restando apenas cerca de $2 \%$ disponível na forma livre. Menos de $1 \%$ da testosterona é convertida em estradiol pela aromatase no testículo, próstata, tecido adiposo, tecido ósseo ou em regiões do sistema nervoso central que contém essa enzima. O principal hormônio derivado da testosterona é a dihidrotestosterona (DHT), produzida na próstata ou no folículo pilo-sebáceo pela ação da enzima 5aredutase. Embora a DHT circule em menor proporção, sua ação é potente, agindo principalmente no processo de diferenciação sexual masculina (Aires, 2008). Uma das funções dos androgênios é controlar o processo de maturação espermática, atuando diretamente no tempo de transporte do espermatozoide ao longo do epidídimo, controlando a viscosidade do fluido luminal e a contratilidade do ducto 
epididimário para garantir que a taxa de trânsito dos gametas seja ideal (Meistrich, 1975; Orgebin-Crist \& Jahad, 1978; Sujarit \& Pholpramool, 1985).

A função testicular é controlada pelo hipotálamo que secreta de forma intermitente o hormônio liberador de gonadotrofinas $(\mathrm{GnRH})$. A hipófise é estimulada pelo $\mathrm{GnRH}$ e libera no mesmo ritmo o hormônio folículo estimulante (FSH) e o hormônio luteinizante (LH), ambos controlam a produção de hormônios e a espermatogênese. $\mathrm{O} \mathrm{LH}$ atua nas células de Leydig regulando a secreção de testosterona, que por sua vez inibe a liberação de $\mathrm{GnRH}$ no hipotálamo com consequente inibição da liberação de LH pela hipófise, provocando dessa forma uma retroalimentação negativa da sua produção. A testosterona somente promove a inibição da liberação de FSH em altas concentrações, no entanto a inibição da liberação desse hormônio ocorre também pela ação da inibina B produzida pelas células de Sertoli (Figura 8) (Aires, 2008).

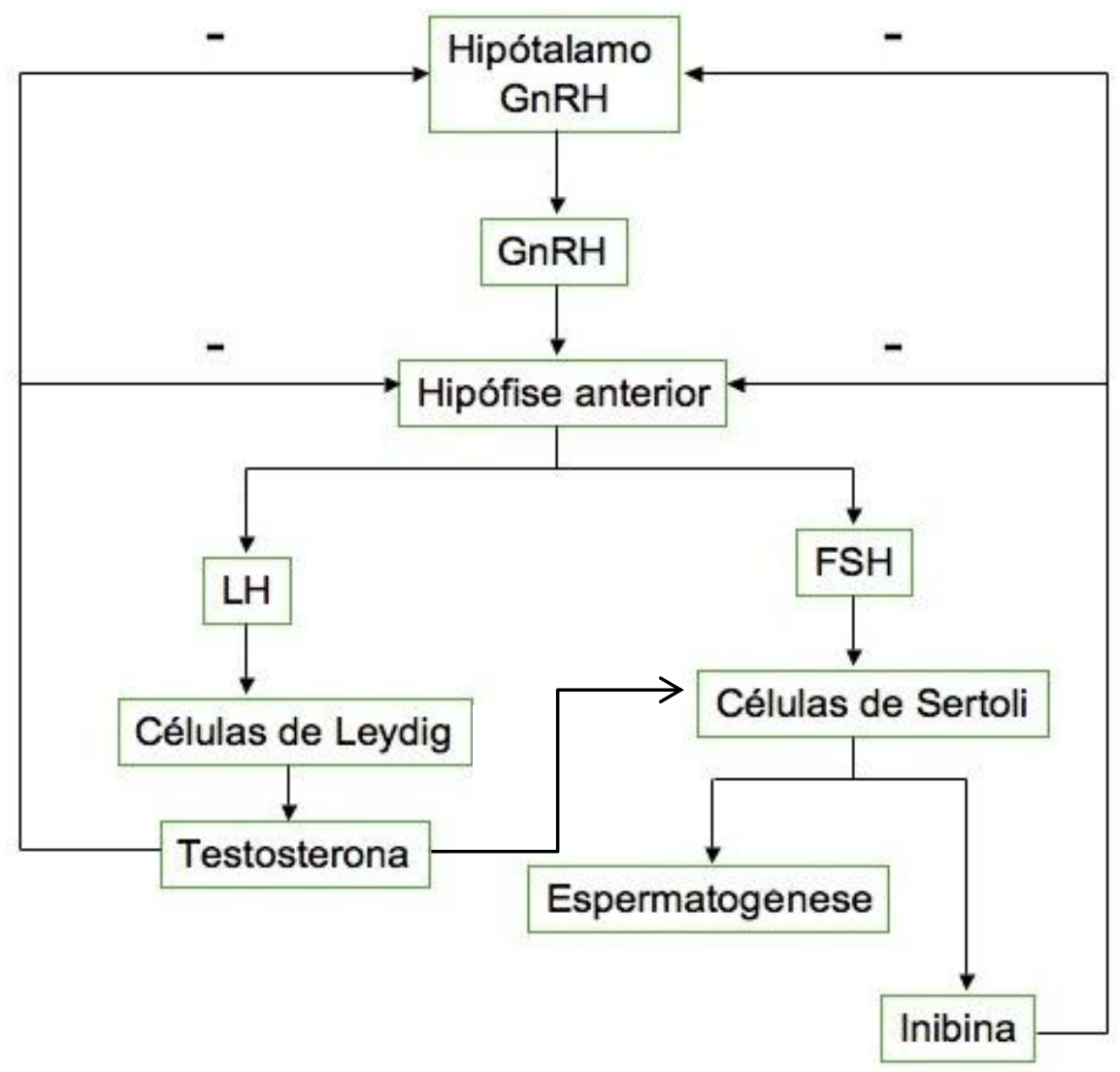

Figura 8. Eixo hipotálamo - hipófise - gônada. (-) indica retroalimentação negativa. Fonte: (http://wikiciencias.casadasciencias.org/wiki/index.php/Regulação-SistemasReprodutores) Adaptado. 


\subsection{Avaliação da função reprodutiva no macho}

Em estudos com animais uma avaliação adequada dos potenciais efeitos de um agente sobre o sistema reprodutivo exige um período prolongado de exposição, da mesma forma, a determinação do início e término da exposição ao agente é igualmente importante (EPA, 1996). Testes apropriados em ratos machos exigem um tempo de tratamento de cerca de 70 dias, que equivale a seis vezes a duração de um ciclo do epitélio seminífero (Amann, 1982). Um ciclo seminífero é uma sequência ordenada de associações entre as células espermatogênicas, também denominada de estádios, que com o decorrer do processo espermatogênico se sucedem em determinada área do epitélio seminífero (Santos et al., 2011).

O Guidelines for Reproductive Toxicicy Risk Assessement (EPA/1996) descreve os pontos importantes para a avaliação da toxicidade reprodutiva masculina. A verificação do peso dos órgãos reprodutivos pode ser útil, de modo que o aumento ou diminuição pode indicar alterações na estrutura do tecido ou mudanças no estado endócrino do animal, já que se trata de órgãos andrógenodependentes. Porém, alterações em outros indicadores de toxicidade reprodutiva mais sensível, não necessariamente irão se refletir no peso do órgão.

A avaliação histopatológica dos órgãos reprodutivos pode ser extremamente útil por proporcionar um indicador relativamente sensível de danos. Nos testículos, a análise histológica além de possivelmente detectar lesões no epitélio germinativo, degeneração ou desorganização celular, permite também identificar a cinética da espermatogênese (EPA, 1996). Embora a toxicidade induzida por agentes químicos seja identificada em sua maioria no testículo, a análise histológica do epidídimo também é importante. Substâncias químicas que causam toxicidade aos testículos podem alterar a quantidade ou qualidade de espermatozoides providos da espermatogênese e consequentemente alterar também na quantidade ou qualidade do esperma ao entrar no epidídimo. Além disso, as perturbações causadas no fluído testicular podem alterar a estrutura e função das células epiteliais do epidídimo (Kempinas \& Klinefelter, 2014). 
O parâmetro de contagem espermática também deve ser avaliado, para tal quantifica-se o número de espermátides no testículo e espermatozoides no epidídimo resistente ao processo de homogeneização. Durante a espermatogênese, o núcleo das espermátides se torna altamente condensado atingindo um nível elevado de maturação, e após esse processo, as espermátides se tornam relativamente resistentes a traumas, como a homogeneização. Todas as outras células são destruídas por esse tratamento restando apenas as espermátides maduras, dessa forma é possível estimar de forma confiável o número de espermátides em fase de maturação final da espermiogênese (Seed et al., 1996). A produção espermática pode ser calculada a partir das contagens no testículo, da mesma forma o tempo de trânsito espermático também pode ser obtido a partir das contagens no epidídimo, mais frequentemente na região da cauda (Amann, 1982; Blazak et al., 1985; Robb et al.,1978).

Investigar a morfologia e motilidade espermática é uma forma prática de avaliar as mudanças qualitativas no esperma e devem ser analisadas a partir de uma pequena quantidade de sêmen provido da cauda do epidídimo ou dos ductos deferentes. Exigem-se as análises nessas regiões porque os espermatozoides da cabeça do epidídimo são imóveis e ainda não estão morfologicamente maduros, já os da cauda e canais deferentes são progressivamente móveis e com um alto nível de maturação morfológica (Amann, 1982). A avaliação morfológica completa identifica anormalidades na cabeça do espermatozoide e na cauda ou flagelo. Existe uma suposta correlação entre agentes que causam mutagenicidade e a sua capacidade de induzir anormalidades na cabeça do espermatozoide, portanto a análise da morfologia tem sido uma variável bastante avaliada em ensaios de toxicidade reprodutiva (EPA, 1996). Na análise da motilidade espermática pode ser utilizado um método de análise seminal computadorizada (computer-assisted sêmen analyses - CASA) (Slott et al., 1991), que adquire de forma rápida e eficiente informações sobre a velocidade do espermatozoide, bem como a amplitude e a frequência. Na ausência desse método, a motilidade pode ser avaliada a partir de amostras frescas utilizando microscopia e estimando a porcentagem de espermatozoides móveis e progressivamente móveis (EPA, 1996).

A função do sistema endócrino também pode ser alterada pela ação de agentes tóxicos que podem afetar qualquer parte do eixo hipotálamo-hipófise- 
gônada. Os efeitos induzidos podem alterar a síntese hormonal, a liberação ou o transporte, assim como o reconhecimento do receptor pelo hormônio e as respostas pós-receptoras. Uma modificação nas concentrações normais de LH, FSH ou testosterona podem diminuir ou cessar a espermatogênese, bem como afetar a função do epidídimo e glândulas acessórias ou prejudicar no comportamento sexual (EPA, 1996).

\subsection{Avaliação comportamental}

O campo na neurotoxicologia envolve o estudo da estrutura e/ou função do sistema nervoso resultante da exposição a agentes químicos ou outros fatores ambientais, bem como as consequências das alterações provocadas por essa exposição. Inicialmente esses estudos envolviam somente a análise da estrutura cerebral por histopatologia, mas atualmente sabe-se que as substâncias neurotóxicas podem alterar também a função do sistema nervoso, se refletindo no comportamento. Portanto a avaliação comportamental também é importante, pois os efeitos comportamentais podem ser um reflexo de mudanças na morfologia celular ou na comunicação entre os neurônios (Moser, 2011).

Vários testes comportamentais têm sido desenvolvidos com diferentes níveis de complexidade. O primeiro nível, considerado mais simples, inclui avaliações de reflexos neurológicos, funções motoras e sensoriais. O segundo nível inclui testes que modelam comportamentos humanos relacionados à ansiedade, depressão e esquizofrenia. Além disso, alguns testes têm como objetivo avaliar a função cognitiva do animal, onde os comportamentos condicionados, de aprendizagem, memória e atenção são avaliados (Moser, 2011). Os modelos animais são considerados a base da investigação pré-clínica sobre a neurobiologia dos transtornos psiquiátricos e são utilizados como ferramentas na busca de novos agentes terapêuticos (Rodgers et al., 1997). Porém existe um consenso de que nenhum dos testes comportamentais que avaliam a depressão e a ansiedade fornece uma medida inquestionável do perfil emocional do animal, pois cada teste individual avalia apenas uma parte desse perfil (Ramos, 2008). 
Historicamente, a tentativa de desenvolvimento de modelos animais de ansiedade obteve pouca atenção na questão da validação animal. Embora haja o reconhecimento dos aspectos subjetivos e ocultos da ansiedade humana, ela é refletida de maneira evidente em comportamentos como, evasão, escape, vocalização ou hipervigilância. Quando observada em animais, tais respostas sugerem um estado emocional análogo ao humano, proporcionando dessa forma a validade necessária para o modelo animal. Porém, na ausência de uma compreensão detalhada da subjetividade da ansiedade humana, torna-se impossível estabelecer homologia entre animais e humanos em padrões de respostas. Muitos modelos animais de ansiedade são baseados na exploração do animal a um ambiente novo e potencialmente perigoso para ele (Rodgers et al., 1997).

\subsubsection{Campo aberto}

O teste do campo aberto (TCA) é um modelo animal comportamental bastante utilizado na investigação da atividade locomotora, bem como no comportamento de ansiedade. Este último é baseado na aversão natural do rato a lugares abertos, quando o animal tende a ter um comportamento de tigmotactismo, no qual ele anda próximo às paredes do aparato (Lamprea et al, 2008). Tratamentos clássicos com benzodiazepínicos ou com agonistas dos receptores $5-\mathrm{HT}_{1 \mathrm{~A}}$ em sua maioria são capazes de induzir um efeito ansiolítico no TCA (Prut \& Belzung, 2003).

Hall (1934) utilizou o campo aberto inicialmente para investigar o comportamento emocional de ratos após privação de alimento, observando mais locomoção, número menor de entradas na área central do aparato e níveis menores de defecação em relação aos animais que se alimentaram. $O$ autor atribuiu os parâmetros de defecação e micção como bons indicadores de reatividade emocional.

Atualmente, o TCA é um dos procedimentos mais populares no campo da psicologia animal. Diferentes versões foram desenvolvidas diferindo na forma do aparato (Figura 9), na iluminação do ambiente e presença de objetos dentro da arena, tais como plataformas ou colunas. Em geral o teste consiste em colocar o animal no centro do aparato e avaliar durante 5 minutos a atividade locomotora 
(número de quadrantes percorridos), frequência de elevação, também chamada de atividade vertical, frequência de grooming ou autolimpeza (movimento das patas anteriores em direção à boca e cabeça), defecação e micção. $O$ aumento do tempo gasto na área central ou da proporção de entradas na parte central pelo total de quadrantes percorridos indica efeito ansiolítico (Prut \& Belzung, 2003).

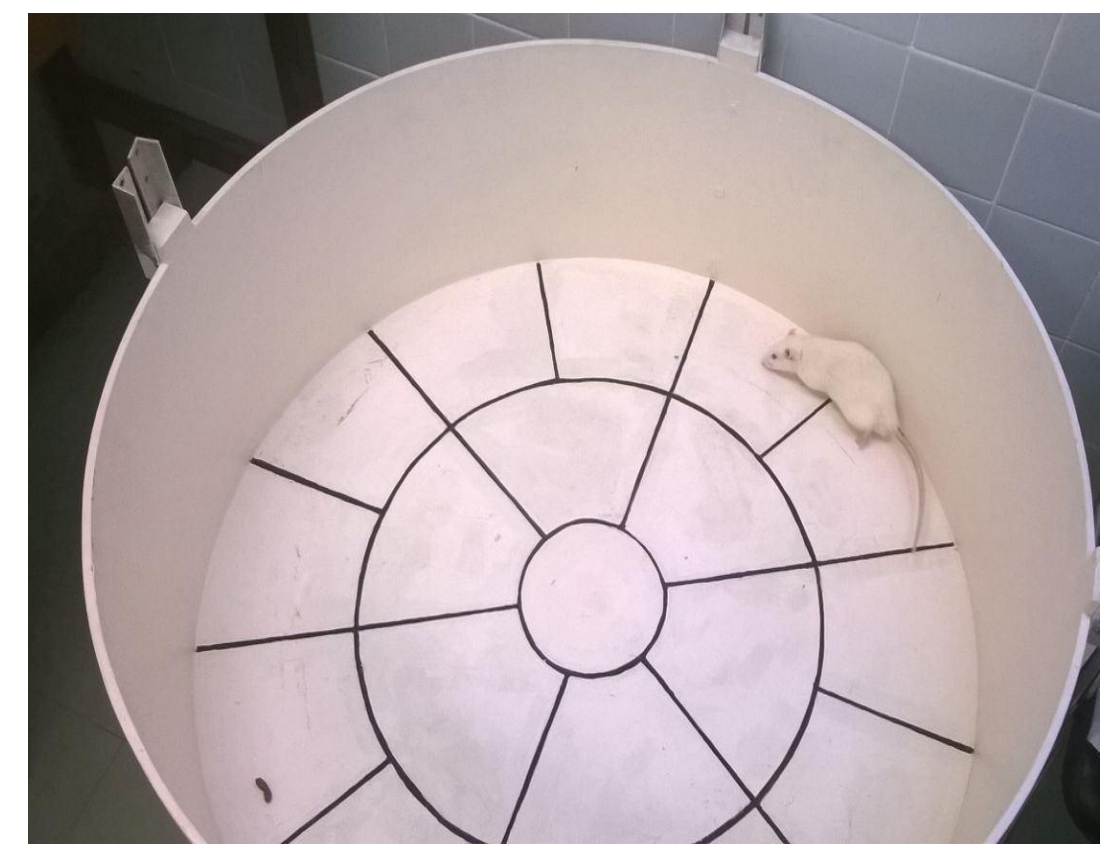

Figura 9. Aparato para realização do teste de campo aberto

\subsubsection{Labirinto em cruz elevado}

O labirinto em cruz elevado (LCE) é um modelo utilizado na investigação préclínica sobre a ansiedade e sua utilização foi validada nos aspectos comportamental, fisiológico e farmacológico (Pellow et al., 1985; Rodgers et al., 1997). Este teste se baseia em observações iniciais de que em labirintos contendo segmentos abertos e fechados, os ratos tendem a explorar mais as regiões fechadas e normalmente evitam aquelas sem paredes quando são confrontados com uma escolha (Rodgers et al., 1997).

Handley \& Mithani (1984) inicialmente observaram que em um labirinto elevado a $70 \mathrm{~cm}$ do chão e contendo dois braços abertos e dois braços fechados dispostos de formas opostas (Figura 10), os ratos evitam os braços abertos. Além disso, a esquiva aos braços abertos é reduzida com agentes ansiolíticos como 0 
diazepam e reforçada com agentes ansiogênicos como a picrotoxina. Portanto os determinantes críticos inversamente relacionados com a ansiedade são o número de entradas e o tempo gasto nos braços abertos, ou seja, quanto maior a porcentagem nessas variáveis menor é a ansiedade do animal (Hogg, 1996).

A atividade locomotora é avaliada pela verificação do número total de entradas nos braços fechados. O tempo gasto na área central do labirinto é correlacionado com um comportamento referido como avaliação de risco (Hogg, 1996; Rodgers et al., 1997). Os eventos de micção, autolimpeza, elevação (apoio nas patas traseiras) e defecação também são quantificados (Hogg, 1996).

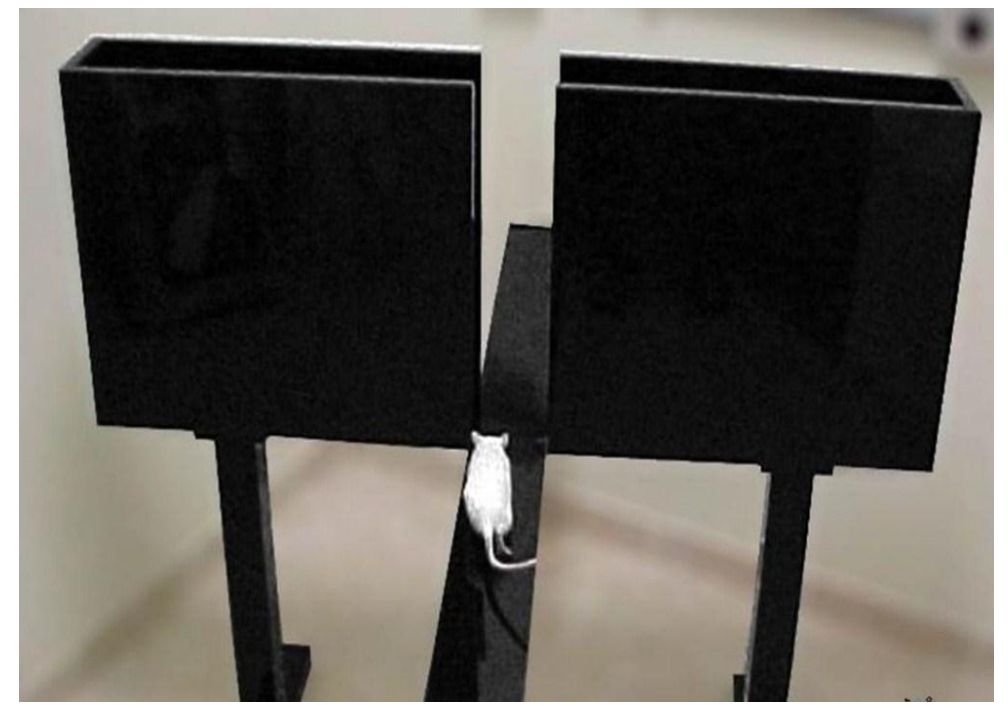

Figura 10. Aparato para realização do teste de labirinto em cruz elevado 


\subsubsection{Natação forçada}

O teste de natação forçada (TNF) é um dos modelos animais mais utilizados para avaliar o potencial antidepressivo de uma substância. O TNF foi originalmente descrito por Porsolt et al, (1978), e se baseia na observação de que quando exposto a água em um cilindro do qual não há escapatória (Figura 11), o animal inicia um comportamento intenso de natação e climbing (comportamentos dirigidos com o intuito de escapar do cilindro), seguido de um comportamento passivo ou imóvel que é reflexo de uma falha na persistência da tentativa de escapar após o estresse ou desespero comportamental. Vários tratamentos com antidepressivos mostram uma redução na quantidade de tempo de imobilidade e aumento dos comportamentos ativos (Slattery \& Cryan, 2012). Existem duas versões que são utilizadas, o teste tradicional e o modificado diferindo em sua configuração experimental. $O$ efeito antidepressivo está relacionado com a diminuição do comportamento de imobilidade, mas desde que não ocorra um aumento da atividade locomotora geral, o que poderia proporcionar um resultado falso positivo. Compostos estimulantes, sedativos ou que prejudicam a atividade locomotora do animal podem trazer resultados falsos positivos e falsos negativos no teste. Um estimulante, por exemplo, pode reduzir o tempo de imobilidade e aumentar a atividade locomotora em outros testes, confundindo dessa forma os resultados no TNF. Portanto é necessária a realização de outros testes que avaliem a atividade locomotora em separado, a fim de determinar se a substância testada afeta a atividade geral do animal (Slattery \& Cryan, 2012). 


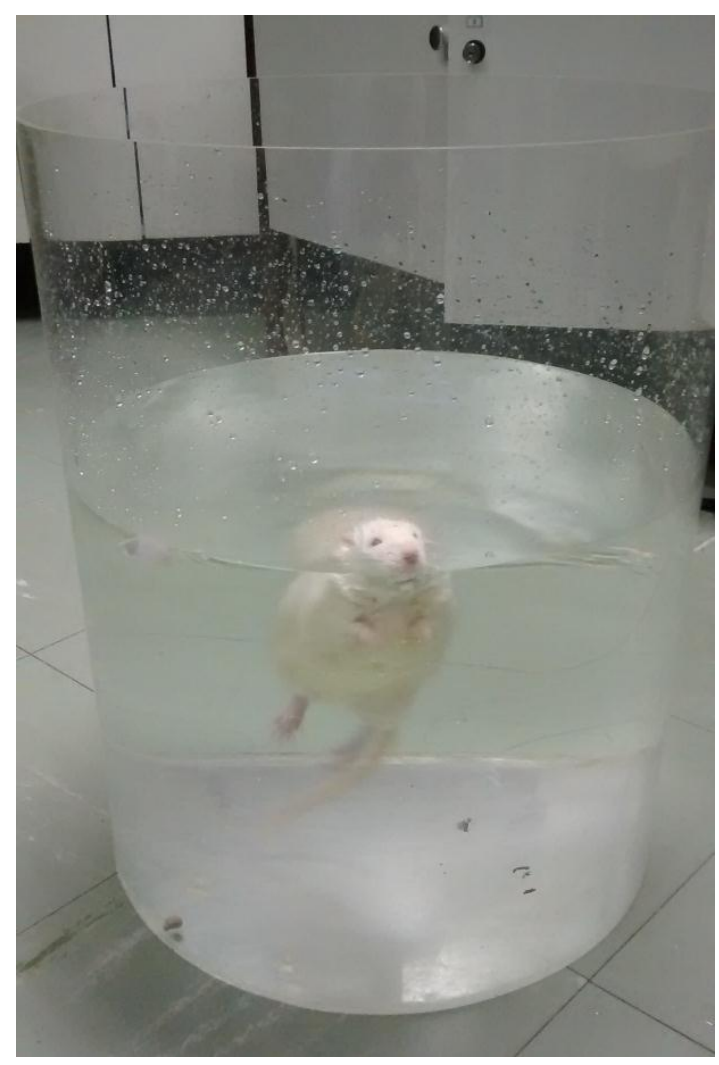

Figura 11. Cilindro de acrílico usado para o teste de natação forçada

O teste de natação forçada padrão é conduzido por um pré-teste de 15 minutos, seguido 24 horas depois por um segundo teste de 5 minutos. Drogas antidepressivas tipicamente são administradas de forma subaguda, 23, 5 e 1 hora antes do teste e dessa forma são previstas para diminuírem a imobilidade (Detke et al., 1997). O TNF é sensível às principais classes de drogas antidepressivas incluindo os antidepressivos tricíclicos e os inibidores da monoamina oxidase, havendo uma correlação significativa entre a dosagem e a eficácia clínica (Willner, 1984). Antidepressivos que inibem a recaptação de norepinefrina, como a desipramina e a maprotilina, reduzem a imobilidade e aumentam o climbing sem afetar na natação. Já os inibidores da recaptação de serotonina, como a fluoxetina e sertralina, diminuem a imobilidade e aumentam a natação, sem afetar no climbing. Dessa forma o TNF permite uma análise dos diferentes padrões de comportamento de drogas que tem um efeito terapêutico comum, distinguindo diferentes sistemas de neurotransmissão (Detke et al., 1997). 


\section{OBJETIVOS:}

\section{Geral:}

Avaliar os efeitos neurocomportamentais e o potencial toxicológico reprodutivo da ayahuasca em ratos machos Wistar após exposição crônica em doses usuais ( $1 \mathrm{X}$ a dose utilizada em uma cerimônia religiosa da UDV) e elevadas (2X, 4X e 8X).

\section{Específicos:}

a) Investigar os efeitos neurocomportamentais da ayahuasca após tratamento crônico utilizando os modelos animais de Campo Aberto, Labirinto em Cruz Elevado e Natação Forçada.

b) Avaliar os indicadores de toxicidade reprodutiva que inclui motilidade e morfologia espermática, análise hormonal, contagem total de espermatozoides, produção espermática diária e tempo de trânsito espermático.

c) Avaliar o potencial toxicológico da ayahuasca nos órgãos reprodutivos através de análise histopatológica do testículo e epidídimo.

d) Investigar os efeitos da exposição crônica de ayahuasca sobre o ganho de peso corpóreo e consumo de ração nos animais tratados.

e) Avaliar as funções renais, hepática, pancreática e de metabolização lipídica através de análise bioquímica sérica.

Este estudo será apresentado em dois capítulos, o primeiro relacionado à avaliação comportamental da ayahuasca e o segundo relacionado à avaliação da toxicidade reprodutiva masculina. Materiais e métodos comuns aos dois capítulos serão apresentados inicialmente e detalhes experimentais específicos serão incluídos em cada capítulo. 


\section{MATERIAIS E MÉTODOS}

\subsection{Animais}

Foram utilizados 72 ratos machos da espécie Rattus novergicus, linhagem Wistar, com idade de quatro semanas e uniformes quanto ao peso $(210 \pm 10 \mathrm{~g})$, provenientes da Granja RG, São Paulo.

Os animais foram mantidos no biotério da Faculdade de Ciências da Saúde da UnB em gaiolas de polipropileno com grade zincada em estante ventilada da Alesco® e passaram por um período de aclimatação de 14 dias antes do início do experimento. Durante todo o experimento os animais foram mantidos em condições controladas de temperatura $\left(23 \pm 2^{\circ} \mathrm{C}\right)$ e ciclo de claro/escuro de $12 \mathrm{~h} / 12 \mathrm{~h}$, e receberam ração comercial para roedores (Purina ${ }^{\circledR}$ ) e água filtrada ad libitum.

O projeto foi aprovado pelo Comitê de Ética no Uso Animal (CEUA) do Instituto de Ciências Biológicas da Universidade de Brasília, UnBdoc $n^{\circ}$ 107766/2010 (Anexo 1). Todos os procedimentos experimentais incluindo condições ambientais, manejo e cuidado dos animais seguiram as recomendações do Guide for the Care and Use of Laboratory Animals e do Guideline for the Testing of Chemicals (OECD, 2003). Também foram seguidas recomendações do Comitê de Ética no Uso Animal (CEUA) da UnB/IB e observada a Lei Arouca 11794/2008.

\subsection{Preparo e aquisição do chá ayahuasca}

O chá ayahuasca utilizado nesse estudo foi cedido em 2011 pelo Núcleo Luz do Oriente da União do Vegetal, com sede em Planaltina-DF. O preparo deste chá, coordenado pelo mestre do Núcleo, foi feito a partir da cocção do cipó mariri colhido

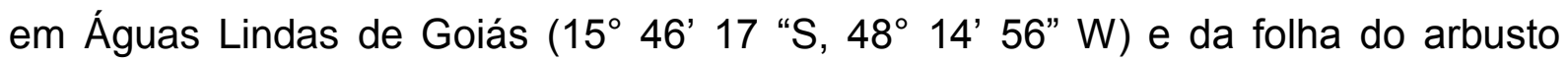

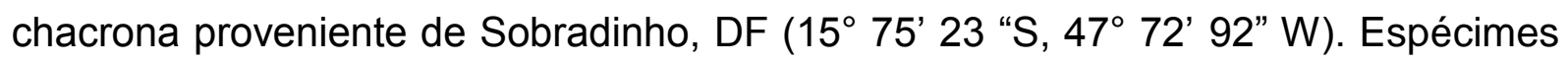
de mariri e chacrona utilizadas para o preparo foram depositadas no herbário da Universidade de Brasília com os respectivos números de referência Azevedo EP 149880 BRAHMS e Trieto B 149879 BRAHMS. 
Durante o preparo o material foi depositado em grandes recipientes, de forma que o mariri e a chacrona eram dispostos em camadas alternadas e recobertos com água (Figura 12). O material foi fervido por 5 horas atingindo uma coloração marrom, coado e armazenado em garrafas esterilizadas de 1 litro. Um volume de 30 litros foi cedido para a pesquisa sendo armazenado no Laboratório de Toxicologia da UnB em freezer $-20^{\circ} \mathrm{C}$.

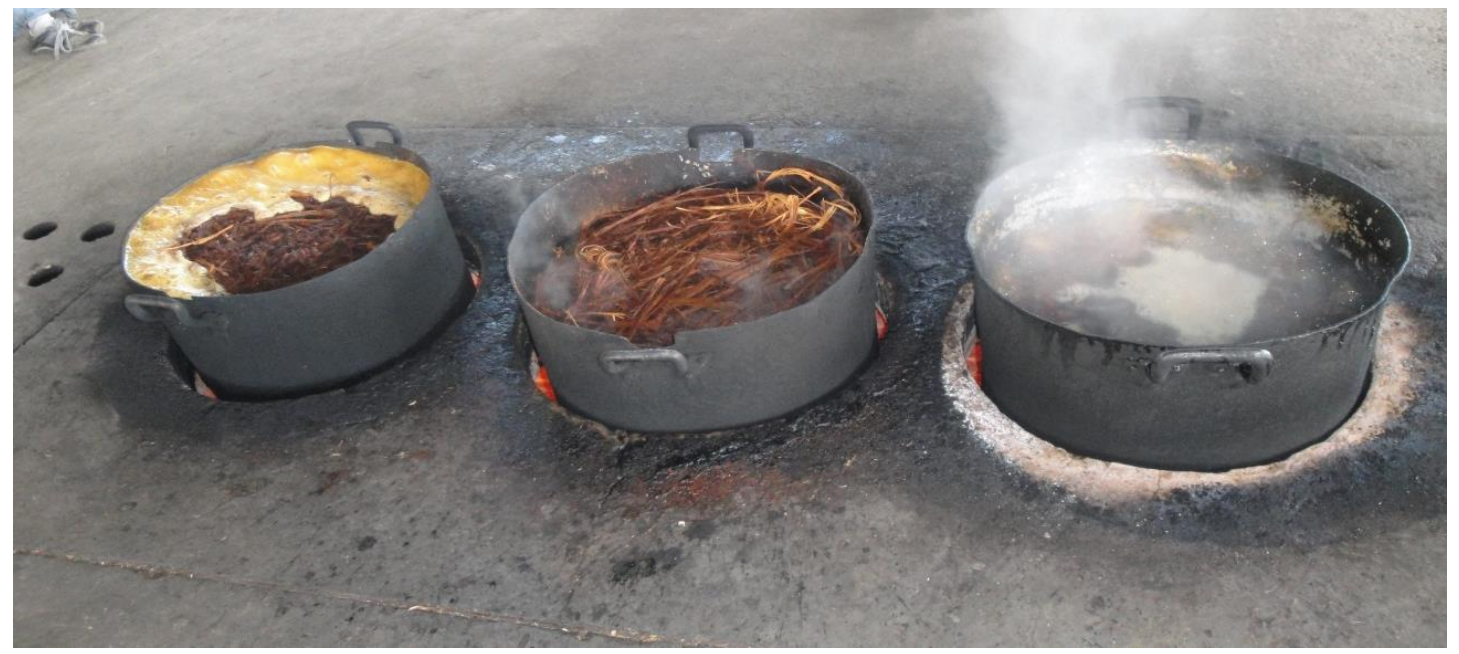

Figura 12. Preparo do chá ayahuasca pela UDV

\subsection{Caracterização química}

A densidade do chá ayahuasca foi determinada a partir da pesagem de 10 amostras de $10 \mathrm{~mL}$ liofilizadas separadamente. Foi calculada a média aritmética e sua densidade foi estimada em $0,1615 \mathrm{~g} / \mathrm{mL}$.

Os padrões de harmalina e harmina, $99,2 \%$ e $98 \%$ de pureza, respectivamente, foram obtidos da Sigma Aldrich. O DMT foi sintetizado pela Prof. Maria Lucília Santos, do Instituto de Química da UnB, conforme metodologia descrita por Qu et al. (2011), sendo a identidade e pureza determinadas por LC-MS/MS (Shimadzu LC sistema acoplado a um espectrofotômetro de massas 4000 QTRAP, Applied Biosystem), ${ }^{1} \mathrm{H}$ and ${ }^{13} \mathrm{C}-\mathrm{NMR}$ (Varian Mercury Plus spectrometer 7.05 operating at $300 \mathrm{MHz}$ for ${ }^{1} \mathrm{H}$ and at $75.46 \mathrm{MHz}$ for ${ }^{13} \mathrm{C}$ ) e LC-MSD TOF (Agilent 1100 Series). 
Os níveis de DMT, harmalina e harmina presentes no chá ayahuasca foram determinados por CG-MS/MS (Trace Ultra coupled with a TSQ Quantum XLS Triple Quadrupole; Thermo Scientific). A análise quantitativa indicou a presença de 0,146 $\mathrm{mg} / \mathrm{mL}$ de DMT, $0,12 \mathrm{mg} / \mathrm{mL}$ de harmalina e $1,56 \mathrm{mg} / \mathrm{mL}$ de harmina.

\subsection{Delineamento experimental}

Para a realização do experimento seguiu-se o protocolo EPA/630/R96/009/1996 (Guidelines for Reproductive Toxicity Risk Assessment) que estabelece as condições necessárias para um estudo toxicológico reprodutivo, tais como, número de animais por grupo e tempo de tratamento. Para o estudo, utilizou-se quatro grupos tratados, um grupo controle negativo e um grupo controle positivo (tratados com fluoxetina; para os testes comportamentais). Os animais foram distribuídos aleatoriamente em cada grupo, perfazendo um total de 12 animais por grupo.

Os grupos experimentais foram tratados por gavagem com ayahuasca nas doses de $1 \mathrm{X}, 2 \mathrm{X}, 4 \mathrm{X}$ e $8 \mathrm{X}$ a dose utilizada em um ritual religioso da União do Vegetal, aproximadamente $150 \mathrm{~mL}$ para um indivíduo de $70 \mathrm{~kg}$ (1X), e contém 234 mg de harmina, 18,3 mg de harmalina e 21,2 mg de DMT (Pic Taylor et al., 2015). O grupo controle foi tratado com água filtrada. As doses selecionadas coincidem com as doses utilizadas no estudo de toxicidade reprodutiva feminina conduzida previamente pelo nosso grupo de pesquisa (da Motta, 2013). Nesse estudo, mais da metade das ratas tratadas diariamente por 15 dias nas doses de $4 \mathrm{X}$ e $8 \mathrm{X}$ foram a óbito após quatro ou cinco dias de tratamento. Diante dessa observação decidiu-se tratar os animais em dias alternados para garantir a sobrevivência dos animais durante todo o período do estudo. O estudo foi realizado durante 70 dias, com administração por gavagem utilizando sonda flexível $n^{\circ} 6$ (Figura 13). A dose de cada animal/grupo foi ajustada pelo peso corpóreo, mantendo um volume final de 2 $\mathrm{mL}$. Foi feita a avaliação clínica diária dos animais e o peso corpóreo e consumo de ração foram verificados a cada três dias.

Dois animais do grupo 8X foram a óbito durante o experimento, o primeiro no $16^{\circ}$ dia de tratamento com sinais de tremores e convulsão minutos após a gavagem, 
e o segundo no $37^{\circ}$ dia por falha na administração (falsa via), sendo observado que todo o material ficou alojado no pulmão.

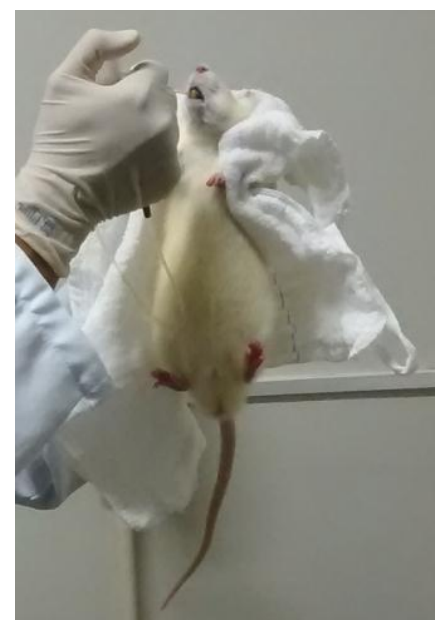

Figura 13. Procedimento de gavagem utilizando sonda flexível

\subsection{Eutanásia e coleta de material biológico}

Os animais foram eutanasiados por exposição ao $\mathrm{CO}_{2}, 24$ horas depois do último tratamento e o sangue foi imediatamente colhido por punção cardíaca e submetido à centrifugação. Dois $\mathrm{mL}$ de soro de cada animal foi armazenado a $20^{\circ} \mathrm{C}$ para posterior análise bioquímica e hormonal.

Baço, fígado, estômago, cérebro, coração, rins, testículos, epidídimos, próstata e vesícula seminal foram retirados e lavados com solução salina $\mathrm{NaCl}$ 0,9\%. Em seguida os órgãos foram avaliados macroscopicamente e pesados em balança calibrada. Após a pesagem os órgãos reprodutivos foram fixados em Bouin para posterior análise histopatológica e os demais em formalina tamponada 10\% por 24 horas, seguido de imersão em álcool 70\% para análises histológicas futuras. 0 cérebro foi mantido em sacarose por três dias com posterior imersão em álcool 70\%. 


\section{AVALIAÇÃO COMPORTAMENTAL DA AYAHUASCA EM RATOS MACHOS APÓS EXPOSIÇÃO AGUDA E CRÔNICA}

Com o objetivo de investigar os potenciais efeitos neurotóxicos da administração crônica de ayahuasca foram realizadas três avaliações comportamentais ao longo do tratamento, utilizando três aparatos: Campo aberto, Labirinto em cruz elevado e natação forçada. A primeira avaliação ocorreu 1 hora após a primeira gavagem com o intuito de investigar o efeito agudo da ayahuasca nas doses testadas. A segunda avaliação ocorreu no $36^{\circ}$ dia de tratamento e a terceira no $70^{\circ}$ dia, ambas realizadas no dia em que a administração não foi feita justamente para acessar o efeito crônico da ayahuasca.

Como controle positivo utilizou-se um grupo $(n=12)$ tratado por gavagem com fluoxetina (FLX) a $10 \mathrm{mg} / \mathrm{kg} \mathrm{pc}$ em dias alternados por um período de 70 dias. Essa dose tratada de forma crônica resulta em níveis plasmáticos de fluoxetina dentro do intervalo terapêutico em humanos (Karpova et al., 2011). Adicionalmente, esse grupo foi tratado com fluoxetina 23 horas e meia, 5 horas e 1 hora antes da primeira avaliação comportamental com o intuito de investigar seu efeito subagudo (Detke et al., 1997).

\section{Teste de campo aberto}

Os animais foram colocados individualmente na área central do campo aberto. Este consiste em uma arena circular de madeira com $96 \mathrm{~cm}$ de diâmetro, cujo chão é divido em 18 quadrantes e um círculo central e as paredes medem 34 $\mathrm{cm}$ de altura (Figura 9). Durante 5 minutos foram quantificados o número de quadrantes adentrados pelo animal com suas quatro patas, o número de elevações (apoio nas patas traseiras), o número de vezes em que o animal retorna ao círculo central, o número de execuções de autolimpeza, quantidade de bolos fecais e micção. Ao final de cada sessão o aparato foi limpo com álcool $5 \%$. 


\section{Labirinto em cruz elevado}

Após o teste do campo aberto o animal foi colocado na área central ( $10 \times 10$ $\mathrm{cm}$ ) do labirinto em cruz elevado que consiste em um aparato de madeira em forma de cruz, elevado a $38 \mathrm{~cm}$ do chão. Este possui dois braços abertos e dois braços fechados, ambos com $50 \mathrm{~cm}$ de comprimento e os braços fechados possuem paredes com $43 \mathrm{~cm}$ de altura (Figura 10).

Durante 5 minutos foram quantificados o número de entradas e o tempo de permanência (s) em cada braço, bem como na área central. Foram quantificados também o número de elevações, autolimpeza, micção e defecação. Ao final do teste o aparato foi limpo com álcool $5 \%$.

\section{Natação forçada}

O Teste da Natação Forçada foi realizado após o Teste do Labirinto em Cruz Elevado em um cilindro de acrílico transparente com $50,5 \mathrm{~cm}$ de altura e $39 \mathrm{~cm}$ de diâmetro, com água $\left(23-25^{\circ} \mathrm{C}\right)$ a uma profundidade de $30 \mathrm{~cm}$ (Figura 11). Este teste foi realizado segundo metodologia descrita por Detke et al. (1997) no qual ocorreram duas sessões de natação: Um pré-teste inicial de 15 minutos seguido 24 horas depois de um teste com duração de 5 minutos. O grupo controle positivo (FLX) foi tratado de forma subaguda 23,55 e 1 hora antes da primeira avaliação comportamental. Durante todo o tratamento crônico este grupo foi tratado por gavagem em dias alternados, similar aos outros grupos do estudo.

Durante o teste foram quantificados os comportamentos predominantes de natação, imobilidade ou climbing a cada 5 segundos, perfazendo um total de 60 escores, bem como o número de bolos fecais (defecação). Ao final do teste o animal foi retirado da água e seco com pano limpo. 


\section{Análise estatística}

Os resultados das avaliações comportamentais foram analisados pela ANOVA Fatorial com pós-teste de Tukey e Dunnett, seguido do Teste $T$ pareado para verificação das diferenças entre uma avaliação e outra. As análises foram realizadas através do programa IBM SPSS Statistics version 20 e os resultados considerados estatisticamente significativos quando $p \leq 0,05$.

\section{RESULTADOS}

\section{Campo aberto}

No teste do campo aberto avaliou-se a atividade locomotora através do número de quadrantes percorridos pelo animal na arena e a atividade ansiolítica foi avaliada pela relação entre a locomoção na área central e a locomoção total. Além disso, os parâmetros de entradas na área central, elevação, autolimpeza, defecação e micção também foram avaliados.

Os resultados da primeira avaliação ( 1 hora) estão mostrados nas Figuras 14 a 16. Na primeira avaliação, não houve diferenças significativas entre os grupos nos parâmetros: idas ao quadrante central, elevação, autolimpeza e micção. Porém houve uma diminuição significativa no número de quadrantes percorridos (locomoção) no grupo de 4X em relação ao grupo controle (Figura 14). A avaliação da relação entre a locomoção na área central pela locomoção total mostrou que os animais tratados com ayahuasca na dose de $4 \mathrm{X}$ obtiveram uma relação significativamente maior comparado ao grupo tratado com fluoxetina (Figura 15). $\mathrm{Na}$ avaliação da defecação observou-se que houve uma diminuição na quantidade de bolos fecais nos animais tratados com fluoxetina (FLX) em relação ao grupo controle (Figura 16). 


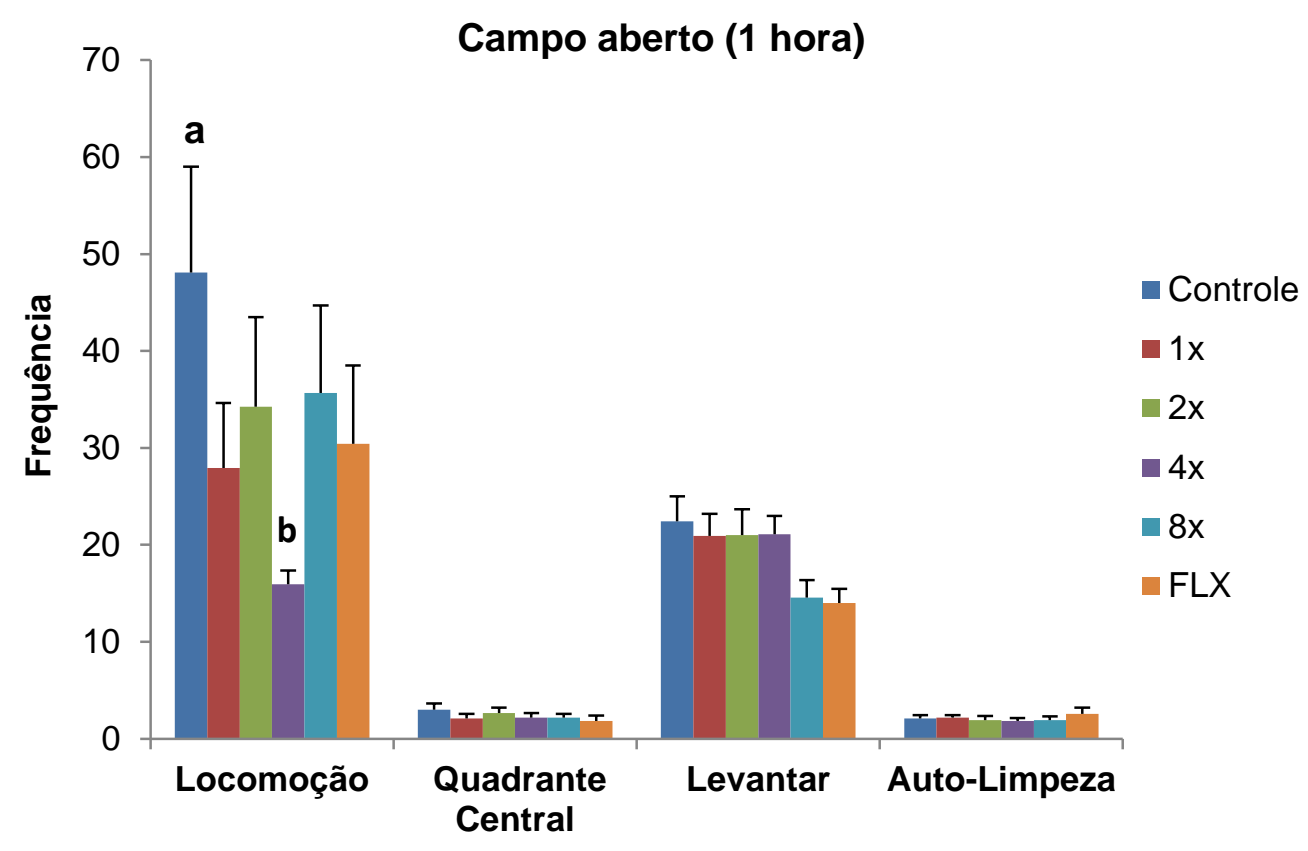

Figura 14. Parâmetros de locomoção, entradas no quadrante central, elevação e autolimpeza avaliados no teste do campo aberto, 1 hora após a primeira gavagem, nos animais do grupo controle negativo, controle positivo (FLX) e tratados com ayahuasca $(n=12)$. Valores expressos em Média \pm SEM. Resultados analisados pela ANOVA com pós-teste de Tukey e Dunnett. Letras diferentes representam diferença significativa.

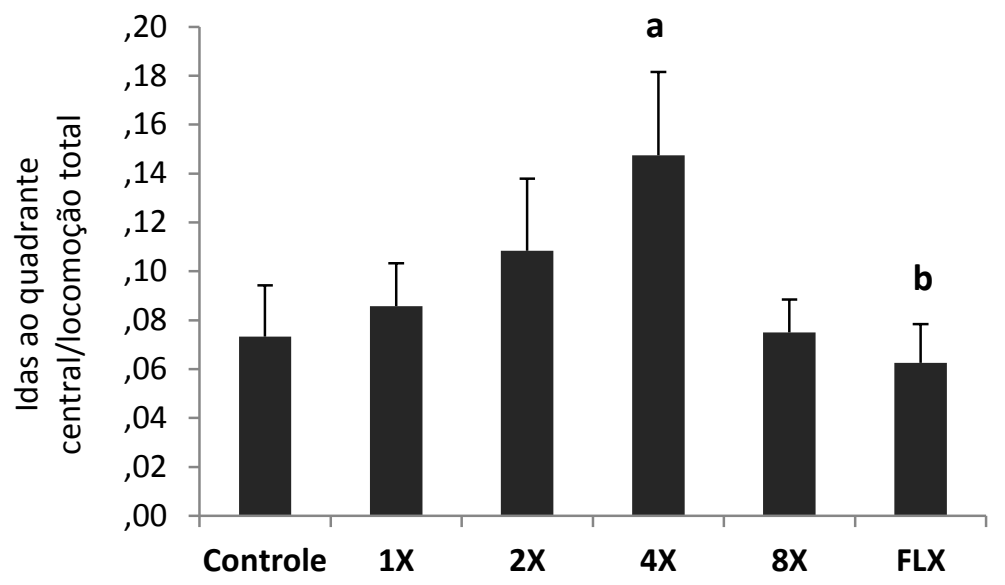

Figura 15. Relação da locomoção na área central pela locomoção total avaliada no campo aberto, 1 hora após a primeira gavagem nos animais do grupo controle negativo, controle positivo ( $F L X)$ e tratados com ayahuasca $(n=12)$. Valores expressos em Média \pm SEM. Resultados analisados pela ANOVA com pós-teste de Tukey e Dunnett. Letras diferentes representam diferença significativa. 


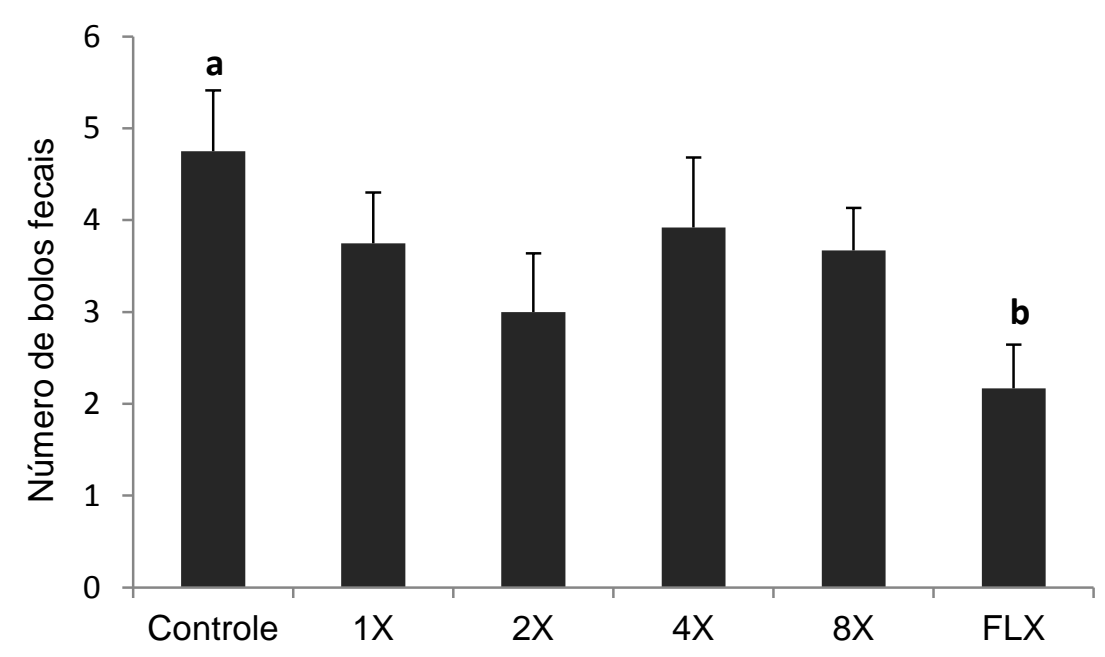

Figura 16. Parâmetro de defecação avaliado no teste do campo aberto, 1 hora após a primeira gavagem, nos animais do grupo controle negativo, controle positivo (FLX) e tratados com ayahuasca $(n=12)$. Valores expressos em Média \pm SEM. Resultados analisados pela ANOVA com pós-teste de Tukey e Dunnett. Letras diferentes representam diferença significativa.

Na segunda avaliação do campo aberto realizada na metade do tratamento (36 ${ }^{\circ}$ dia) observou-se uma diminuição significativa na frequência de elevação dos animais tratados com ayahuasca nas doses de $2 \mathrm{X}, 4 \mathrm{X}$ e $8 \mathrm{X}$ em relação ao grupo controle positivo (FLX) (Figura 17). Da mesma forma observou-se uma diminuição na frequência de idas ao quadrante central nos animais do grupo de $2 \mathrm{X}$ e $8 \mathrm{X}$ comparado ao grupo controle positivo (Figura 18A). A análise da relação entre a locomoção na área central pela locomoção total mostrou que os animais tratados com fluoxetina obtiveram uma relação significativamente maior em relação a todos os outros grupos (Figura 18B). Os parâmetros de locomoção, autolimpeza, defecação e miç̧ão foram estatisticamente iguais em todos os grupos. 


\section{Campo aberto $\left(36^{\circ}\right.$ dia $)$}

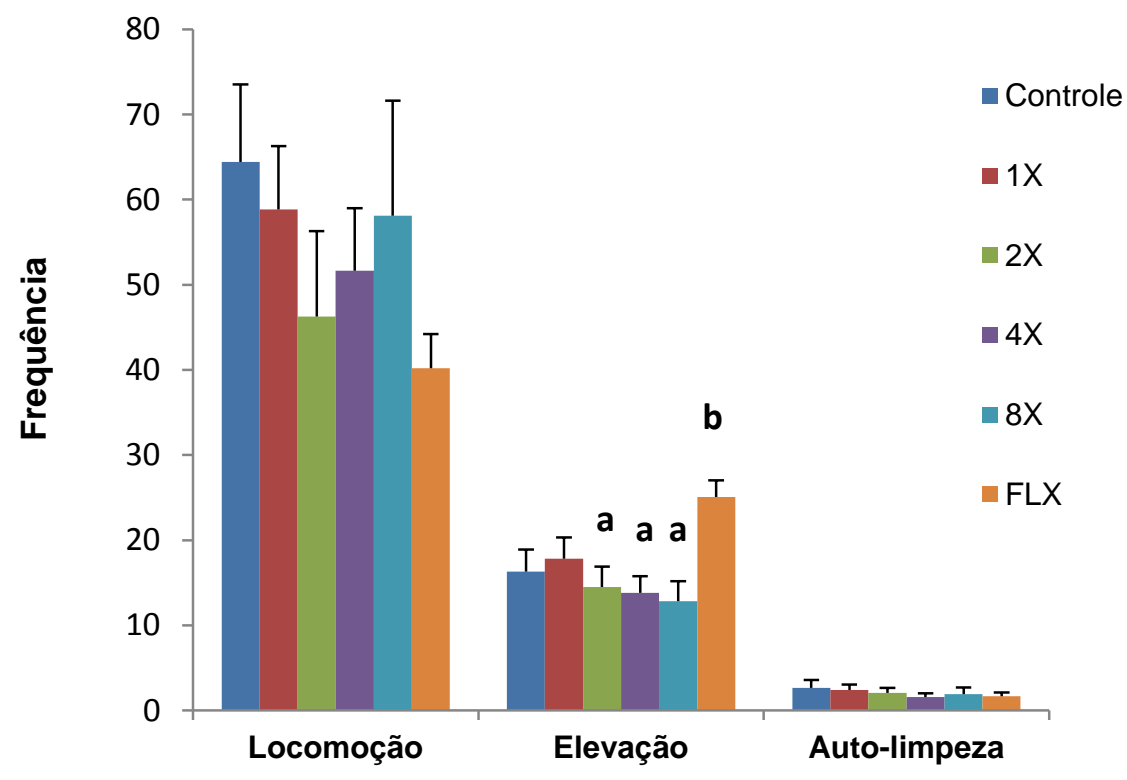

Figura 17. Parâmetros de locomoção, elevação e autolimpeza avaliados no teste do campo aberto, no $36^{\circ}$ dia de tratamento, nos animais do grupo controle negativo $(n=12)$, controle positivo ( $F L X, n=12$ ) e tratados com ayahuasca (grupos $1 X, 2 X, 4 X$; $n=12$; grupo $8 X ; n=11$ ). Valores expressos em Média $\pm S E M$. Resultados analisados pela ANOVA com pós-teste de Tukey e Dunnett. Letras diferentes representam diferença significativas. 
A
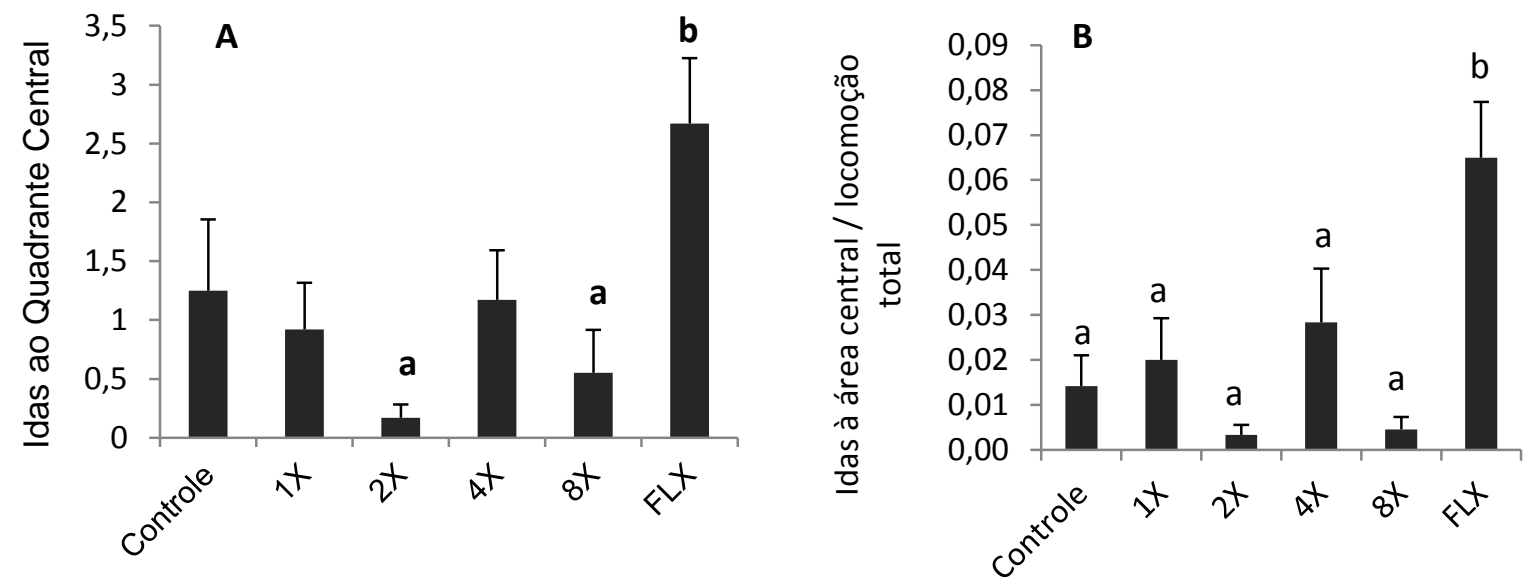

Figura 18. Frequência de idas ao quadrante central $(\mathbf{A})$ e relação entre a locomoção na área central pela locomoção total (B) avaliada no teste do campo aberto, no $36^{\circ}$ dia de tratamento, nos animais do grupo controle negativo $(n=12)$, controle positivo ( $F L X, n=12$ ) e tratados com ayahuasca (grupos $1 X, 2 X, 4 X ; n=12$; grupo 8X; $n=11$ ). Valores expressos em Média \pm SEM. Resultados analisados pela ANOVA com pósteste de Tukey e Dunnett. Letras diferentes representam diferença significativas.

$\mathrm{Na}$ terceira avaliação ocorrida no final do tratamento $\left(70^{\circ} \mathrm{dia}\right)$ não foram observadas diferenças significativas entre os grupos em todos os parâmetros avaliados no campo aberto (Figura 19).

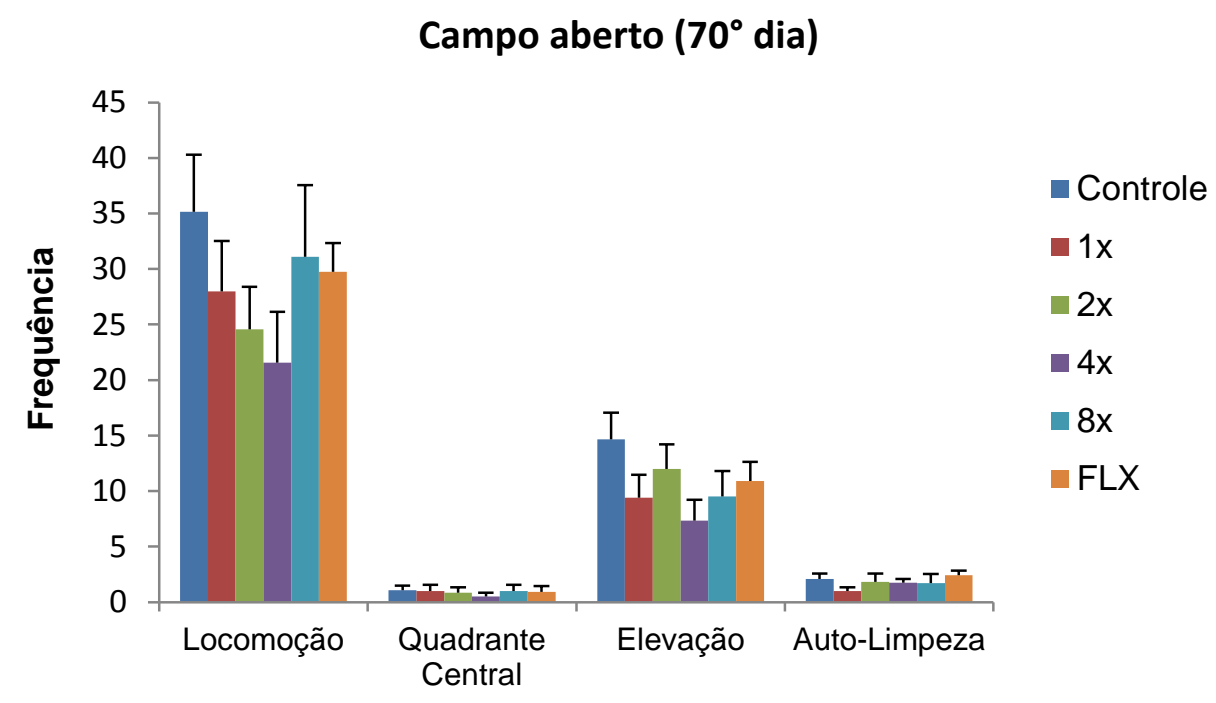

Figura 19. Parâmetros de locomoção, idas ao quadrante central, elevação e autolimpeza avaliados no teste do campo aberto, no $70^{\circ}$ dia de tratamento, nos animais do grupo controle negativo ( $n=12$ ), controle positivo ( $F L X ; n=12)$ e tratados com ayahuasca (grupos $1 \mathrm{X}, 2 \mathrm{X}, 4 \mathrm{X}, \mathrm{n}=12$; grupo $8 \mathrm{X}, \mathrm{n}=10$ ). Valores expressos em Média \pm SEM. Resultados analisados pela ANOVA com pós-teste de Tukey e Dunnett. 
Foi realizada a análise comparativa da segunda e terceira avaliação comportamental, ocorridas na metade e no final do tratamento, respectivamente, para verificação da tendência do comportamento de ida ao quadrante central avaliado no campo aberto. Houve uma diminuição significativa na frequência de idas ao quadrante central nos animais tratados com FLX, da mesma forma houve uma diminuição dessa frequência nos animais do grupo controle negativo e tratados com ayahuasca na dose de $4 \mathrm{X}$, porém não significativa. Os grupos de $2 \mathrm{X}$ e $8 \mathrm{X}$ obtiveram um aumento na frequência, mas não foi significativo estatisticamente (Figura 20A). Analisando a relação de idas ao quadrante central pela locomoção, da segunda para a terceira avaliação comportamental, observou-se uma diminuição quase significativa no grupo controle positivo ( $F L X ; p=0.06$ ) (Figura 20B). $O$ grupo $4 X$ mostrou a mesma tendência, porém não significativa.

A

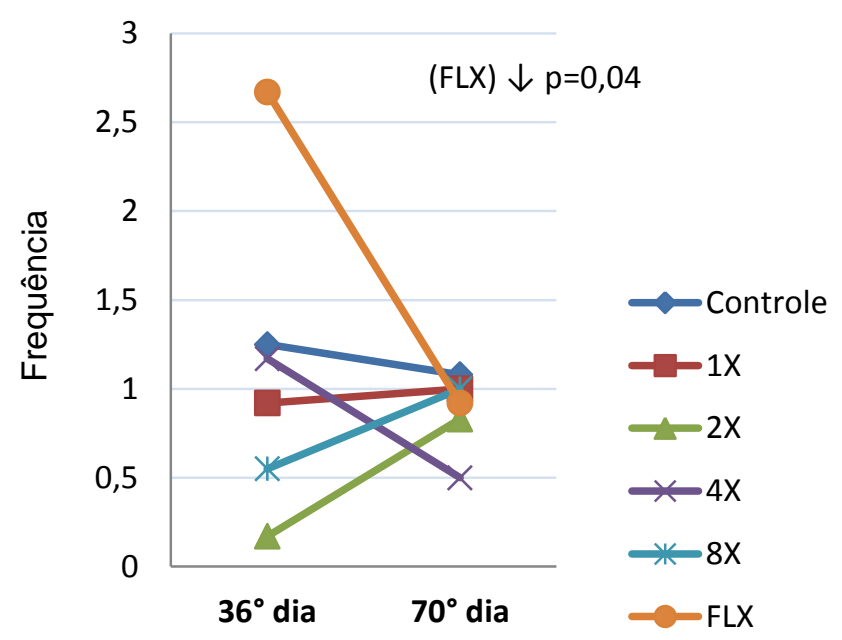

B

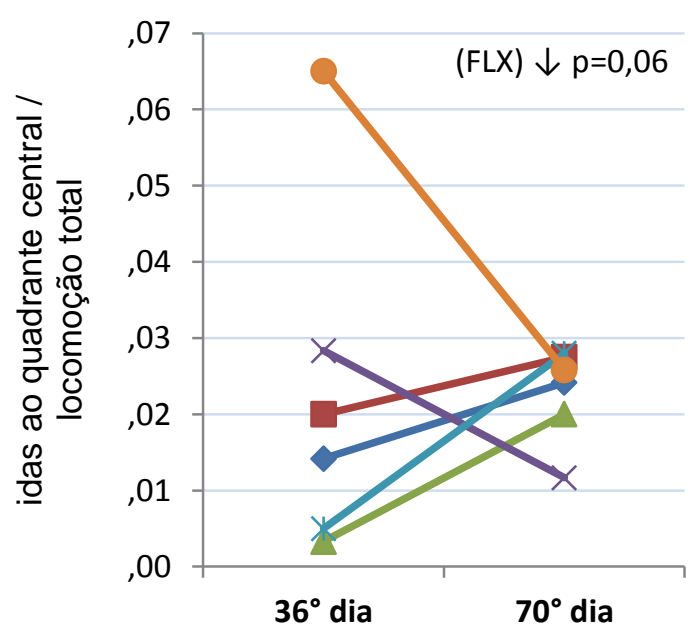

Figura 20. Frequência de idas ao quadrante central $(\mathbf{A})$ e relação entre a locomoção na área central pela locomoção total (B), dos animais do grupo controle positivo $(n=12)$, controle negativo $(n=12)$ e tratados com ayahuasca (grupos $1 X, 2 X, 4 X$, $n=12$; grupo $8 X, n=10$ ), avaliada no teste do campo aberto no $36^{\circ}$ dia de tratamento e no $70^{\circ}$ dia de tratamento; $\downarrow$ indica diminuição; mudanças estatisticamente significativas quando $p \leq 0,05$. Resultados analisados pelo Teste T pareado. 


\section{Labirinto em cruz elevado}

$\mathrm{Na}$ primeira avaliação comportamental do Labirinto em Cruz Elevado realizado 1 hora após a primeira gavagem, observou-se que os animais tratados com FLX obtiveram um tempo de permanência maior no braço fechado comparado aos animais tratados com ayahuasca na dose de 1X. O tempo de permanência no braço aberto e no centro não diferiu estatisticamente entre os grupos (Figura 21).

Na segunda e terceira avaliação comportamental não se observou diferenças significativas entre os grupos no tempo de permanência de ambas as regiões do Labirinto em Cruz Elevado (Figura 22 - 23). Em todas as avaliações não foram observadas diferenças significativas entre os grupos nos parâmetros: entradas nos braços fechados, entradas nos braços abertos, elevação, autolimpeza, fezes e urina (Tabelas $1-3$ ).

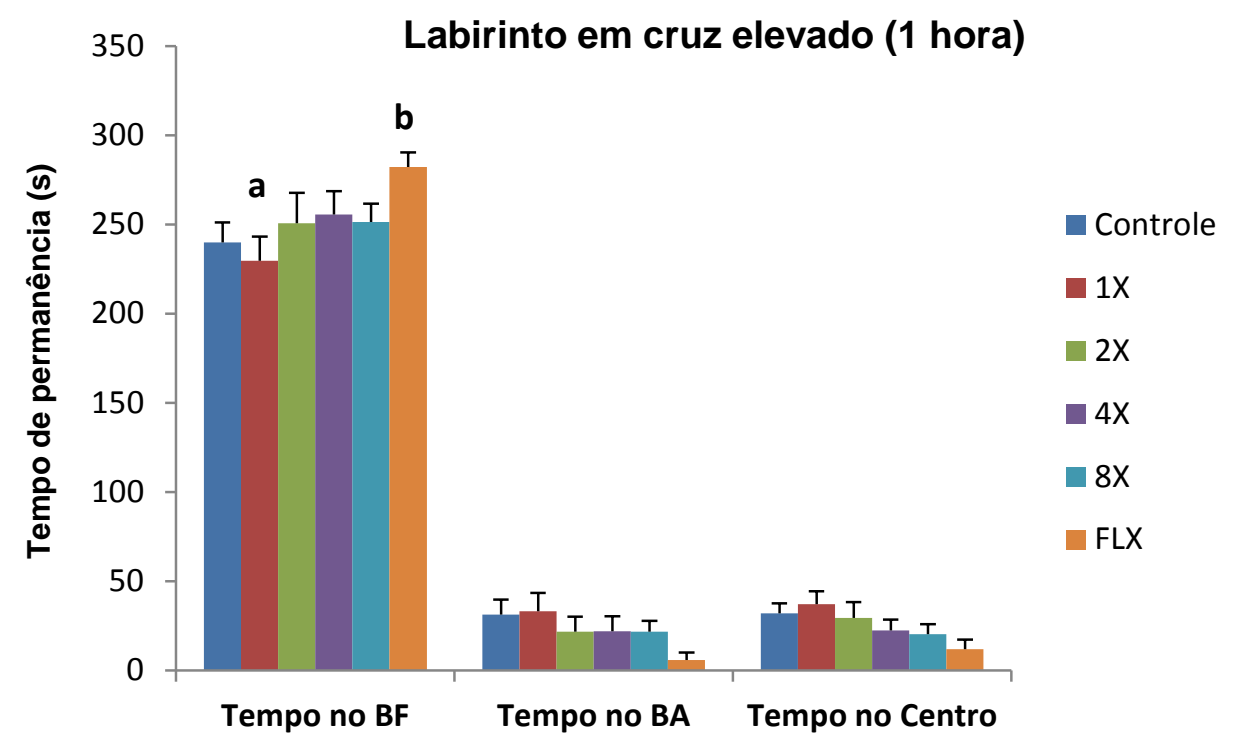

Figura 21. Tempo de permanência no braço fechado (BF), braço aberto (BA), e no centro, dos animais do grupo controle negativo, controle positivo e tratados com ayahuasca $(n=12)$, avaliado no labirinto em cruz elevado, 1 hora após a primeira gavagem. Resultados analisados pela ANOVA com pós-teste de Tukey e Dunnett. 


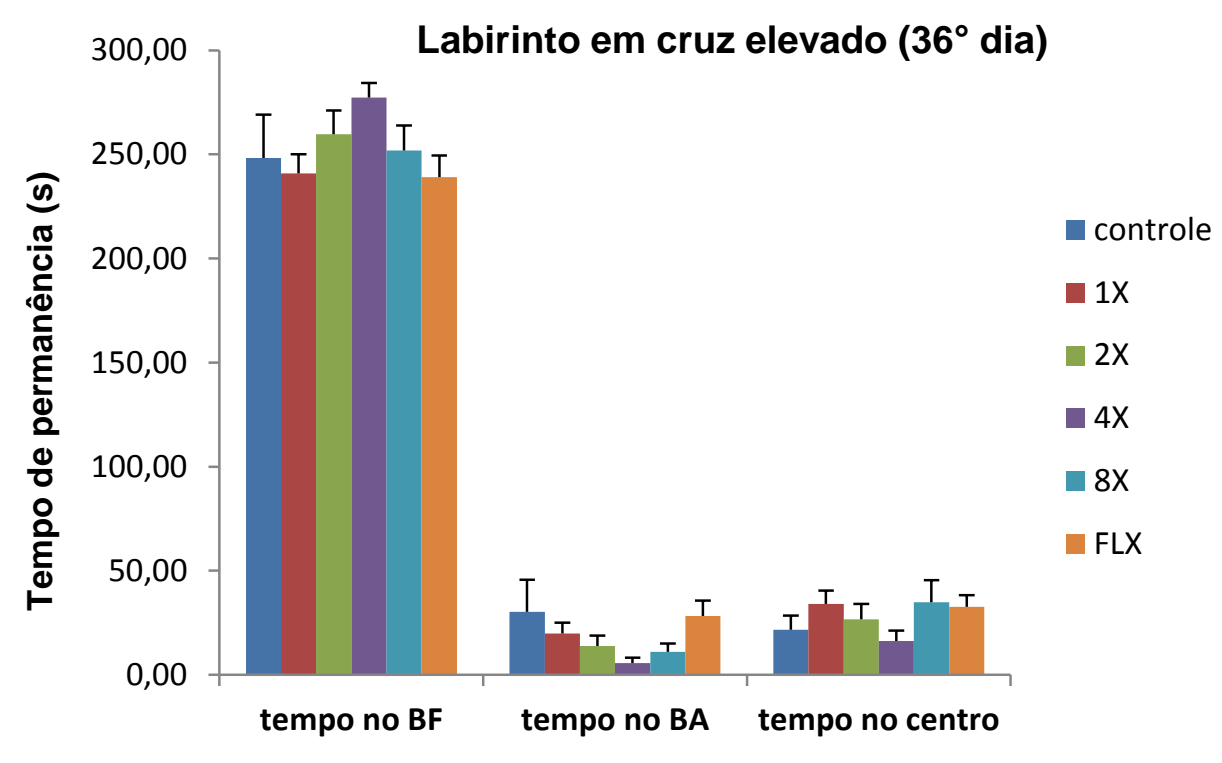

Figura 22. Tempo de permanência no braço fechado (BF), braço aberto (BA), e no centro, dos animais do grupo controle negativo $(n=12)$, controle positivo $(n=12)$ e tratados com ayahuasca (grupos $1 \mathrm{X}, 2 \mathrm{X}, 4 \mathrm{X}, \mathrm{n}=12$; grupo $8 \mathrm{X}, \mathrm{n}=11$ ) avaliado no labirinto em cruz elevado, no $36^{\circ}$ dia de tratamento (metade). Resultados analisados pela ANOVA com pós-teste de Tukey e Dunnett.

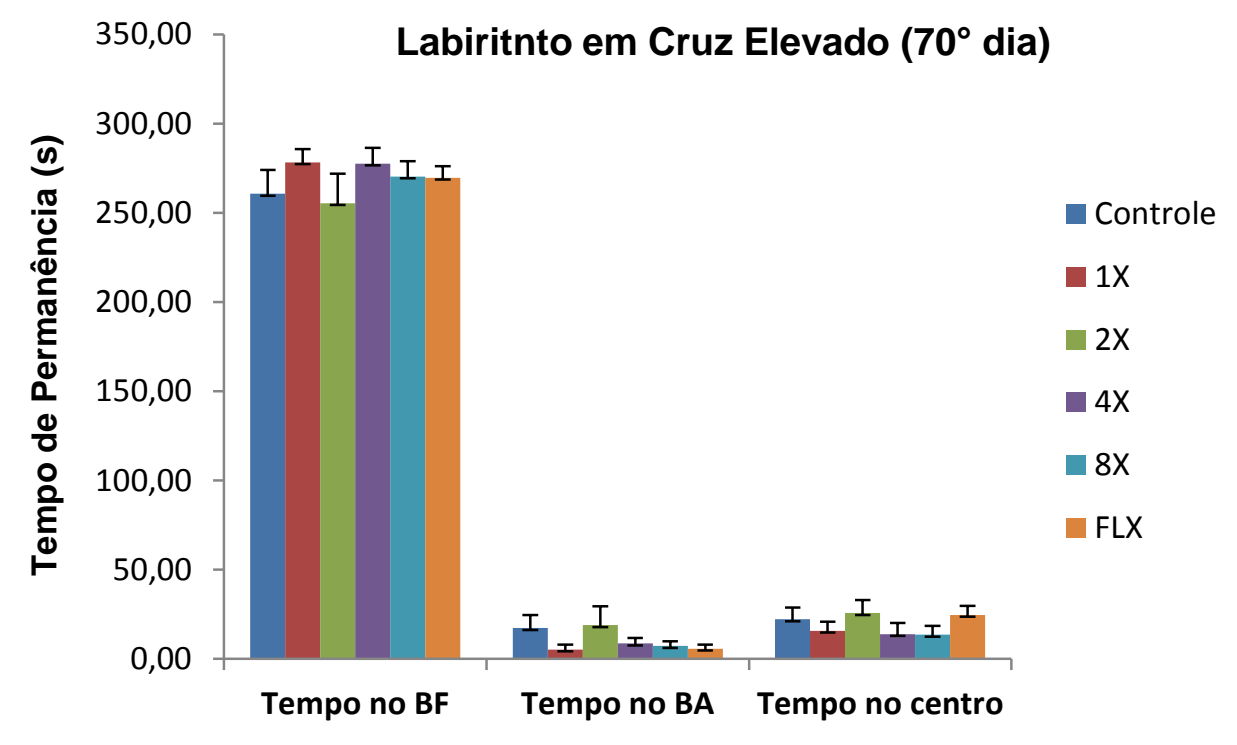

Figura 23. Tempo de permanência no braço fechado (BF), braço aberto (BA), e no centro, dos animais do grupo controle negativo $(n=12)$, controle positivo $(n=12)$ e tratados com ayahuasca (grupos $1 \mathrm{X}, 2 \mathrm{X}, 4 \mathrm{X}, \mathrm{n}=12$; grupo $8 \mathrm{X}, \mathrm{n}=10$ ), avaliado no labirinto em cruz elevado, no $70^{\circ}$ dia de tratamento (final). Resultados analisados pela ANOVA com pós-teste de Tukey e Dunnett. 
Tabela 1. Parâmetros avaliados no teste do labirinto em cruz elevado nos animais do grupo controle negativo, controle positivo (FLX) e tratados com ayahuasca, 1 hora após a primeira gavagem. Valores expressos em Média \pm SEM, $n=12$.

\begin{tabular}{lcccccc}
\hline & Controle & $\mathbf{1 X}$ & $\mathbf{2 X}$ & $\mathbf{4 X}$ & $\mathbf{8 X}$ & $\mathbf{F L X}$ \\
\hline $\begin{array}{l}\text { Entradas } \\
\text { nos BF }\end{array}$ & $6,1 \pm 0,9$ & $5,7 \pm 0,9$ & $5,7 \pm 1,1$ & $4,2 \pm 0,8$ & $4,7 \pm 2,9$ & $3,3 \pm 1,1$ \\
$\begin{array}{l}\text { Entradas } \\
\text { nos BA }\end{array}$ & $2,2 \pm 0,5$ & $2,1 \pm 0,6$ & $1,8 \pm 0,7$ & $1,4 \pm 0,4$ & $1,6 \pm 0,4$ & $0,6 \pm 0,5$ \\
Elevação & $16,5 \pm 0,9$ & $17,7 \pm 1,2$ & $16,6 \pm 2,0$ & $12,8 \pm 1,5$ & $14,5 \pm 1,1$ & $15,7 \pm 1,2$ \\
Autolimpe & $0,7 \pm 0,2$ & $0,3 \pm 0,2$ & $0,5 \pm 0,3$ & $1,0 \pm 0,3$ & $0,6 \pm 0,3$ & $0,7 \pm 0,3$ \\
za & & & & & & \\
Fezes & $0,7 \pm 0,2$ & $0,6 \pm 0,1$ & $0,9 \pm 0,4$ & $0,0 \pm 0,0$ & $1,4 \pm 0,8$ & $0,7 \pm 0,3$ \\
Urina & $1,7 \pm 0,5$ & $1,1 \pm 0,3$ & $1,3 \pm 0,4$ & $1,7 \pm 0,3$ & $1,5 \pm 0,3$ & $1,7 \pm 0,3$ \\
\hline
\end{tabular}

Resultados analisados pela ANOVA com pós-teste de Tukey e Dunnett.

Tabela 2. Parâmetros avaliados no teste do labirinto em cruz elevado nos animais do grupo controle negativo, controle positivo (FLX) e tratados com ayahuasca, no $36^{\circ}$ dia de tratamento. Valores expressos em Média \pm SEM.

\begin{tabular}{lcccccc}
\hline & $\begin{array}{c}\text { Controle } \\
(\mathbf{n = 1 2})\end{array}$ & $\begin{array}{c}\mathbf{1 X} \\
\mathbf{( n = 1 2 )}\end{array}$ & $\begin{array}{c}\mathbf{2 X} \\
\mathbf{( n = 1 2 )}\end{array}$ & $\begin{array}{c}\mathbf{4 X} \\
(\mathbf{n}=\mathbf{1 2})\end{array}$ & $\begin{array}{c}\mathbf{8 X} \\
\mathbf{( n = 1 1 )}\end{array}$ & $\begin{array}{c}\mathbf{F L X} \\
\mathbf{( n = 1 2 )}\end{array}$ \\
\hline $\begin{array}{l}\text { Entradas } \\
\text { nos BF }\end{array}$ & $5,9 \pm 1,0$ & $7,2 \pm 0,6$ & $5,9 \pm 1,4$ & $4,5 \pm 1,0$ & $5,7 \pm 0,8$ & $7,3 \pm 0,8$ \\
$\begin{array}{l}\text { Entradas } \\
\text { nos BA }\end{array}$ & $1,9 \pm 0,8$ & $1,2 \pm 0,3$ & $1,3 \pm 0,5$ & $0,4 \pm 0,2$ & $1,0 \pm 0,3$ & $2,2 \pm 0,6$ \\
Elevação & $19,3 \pm 1,9$ & $19,1 \pm 2,1$ & $19,2 \pm 2,1$ & $14,4 \pm 1,3$ & $16,6 \pm 1,9$ & $19,6 \pm 1,8$ \\
$\begin{array}{l}\text { Autolimpe } \\
\text { za }\end{array}$ & $1,4 \pm 0,4$ & $0,7 \pm 0,4$ & $0,8 \pm 0,3$ & $0,4 \pm 0,3$ & $0,8 \pm 0,4$ & $0,2 \pm 0,1$ \\
Fezes & $0,1 \pm 0,1$ & $0,4 \pm 0,3$ & $0,2 \pm 0,1$ & $0,4 \pm 0,2$ & $0,3 \pm 0,1$ & $0,4 \pm 0,2$ \\
Urina & $1,1 \pm 0,3$ & $1,8 \pm 0,5$ & $2,1 \pm 0,3$ & $1,3 \pm 0,3$ & $1,9 \pm 0,3$ & $2,5 \pm 0,5$ \\
\hline
\end{tabular}

. Resultados analisados pela ANOVA com pós-teste de Tukey e Dunnett. 
Tabela 3. Parâmetros avaliados no teste do labirinto em cruz elevado nos animais do grupo controle negativo, controle positivo e tratados com ayahuasca, no $70^{\circ}$ dia de tratamento. Valores expressos em Média \pm SEM.

\begin{tabular}{lcccccc}
\hline & $\begin{array}{c}\text { Controle } \\
(\mathbf{n = 1 2})\end{array}$ & $\begin{array}{c}\mathbf{1 X} \\
\mathbf{( n = 1 2 )}\end{array}$ & $\begin{array}{c}\mathbf{2 X} \\
(\mathbf{n = 1 2})\end{array}$ & $\begin{array}{c}\mathbf{4 X} \\
(\mathbf{n = 1 2})\end{array}$ & $\begin{array}{c}\mathbf{8 X} \\
(\mathbf{n = 1 0})\end{array}$ & $\begin{array}{c}\text { FLX } \\
(\mathbf{n}=\mathbf{1 2})\end{array}$ \\
\hline $\begin{array}{lcccc}\text { Entradas nos } \\
\text { BF }\end{array}$ & $6,2 \pm 0,9$ & $4,6 \pm 0,7$ & $5,6 \pm 1,0$ & $4,8 \pm 0,7$ & $6,0 \pm 1,0$ & $7,0 \pm 0,8$ \\
Entradas nos & $1,5 \pm 0,6$ & $0,3 \pm 0,2$ & $1,1 \pm 0,6$ & $0,5 \pm 0,2$ & $0,8 \pm 0,3$ & $0,5 \pm 0,2$ \\
BA & & & & & & \\
Elevação & $16,4 \pm 2,2$ & $16,1 \pm 2,3$ & $17,8 \pm 3,2$ & $14,4 \pm 1,5$ & $15,0 \pm 2,7$ & $16,7 \pm 1,9$ \\
Autolimpeza & $1,1 \pm 0,2$ & $0,8 \pm 0,3$ & $0,6 \pm 0,2$ & $0,5 \pm 0,2$ & $0,7 \pm 0,3$ & $0,7 \pm 0,2$ \\
Fezes & $0,3 \pm 0,2$ & $0,2 \pm 0,1$ & $0,2 \pm 0,2$ & $0,7 \pm 0,3$ & $0,4 \pm 0,2$ & $0,2 \pm 0,1$ \\
Urina & $1,8 \pm 0,4$ & $1,2 \pm 0,3$ & $2,3 \pm 0,6$ & $1,2 \pm 0,4$ & $1,5 \pm 0,5$ & $2,9 \pm 0,6$ \\
\hline
\end{tabular}

Resultados analisados pela ANOVA com pós-teste de Tukey e Dunnett.

$\mathrm{Na}$ análise comparativa da segunda e terceira avaliação comportamental do labirinto em cruz elevado observou-se um aumento significativo no tempo de permanência nos braços fechados e uma diminuição no tempo de permanência nos braços abertos dos animais do grupo controle positivo (FLX) e tratados com ayahuasca na dose de $1 \mathrm{X}$ (Figura $24 \mathrm{~A}-\mathrm{B}$ ). Por outro lado, o grupo de $2 \mathrm{X}$ demonstrou uma diminuição do tempo de permanência nos braços fechados e um aumento do tempo nos braços abertos, da segunda avaliação para terceira, mas não significativa estatisticamente (Figura 24 A - B).

Foi verificada uma diminuição significativa no tempo de permanência no centro do LCE, da segunda avaliação para a terceira, nos animais do grupo 1X. O grupo de $8 \mathrm{X}$ e o controle positivo também apresentaram uma diminuição nesse tempo, mas não significativa (Figura $24 \mathrm{C}$ ). 

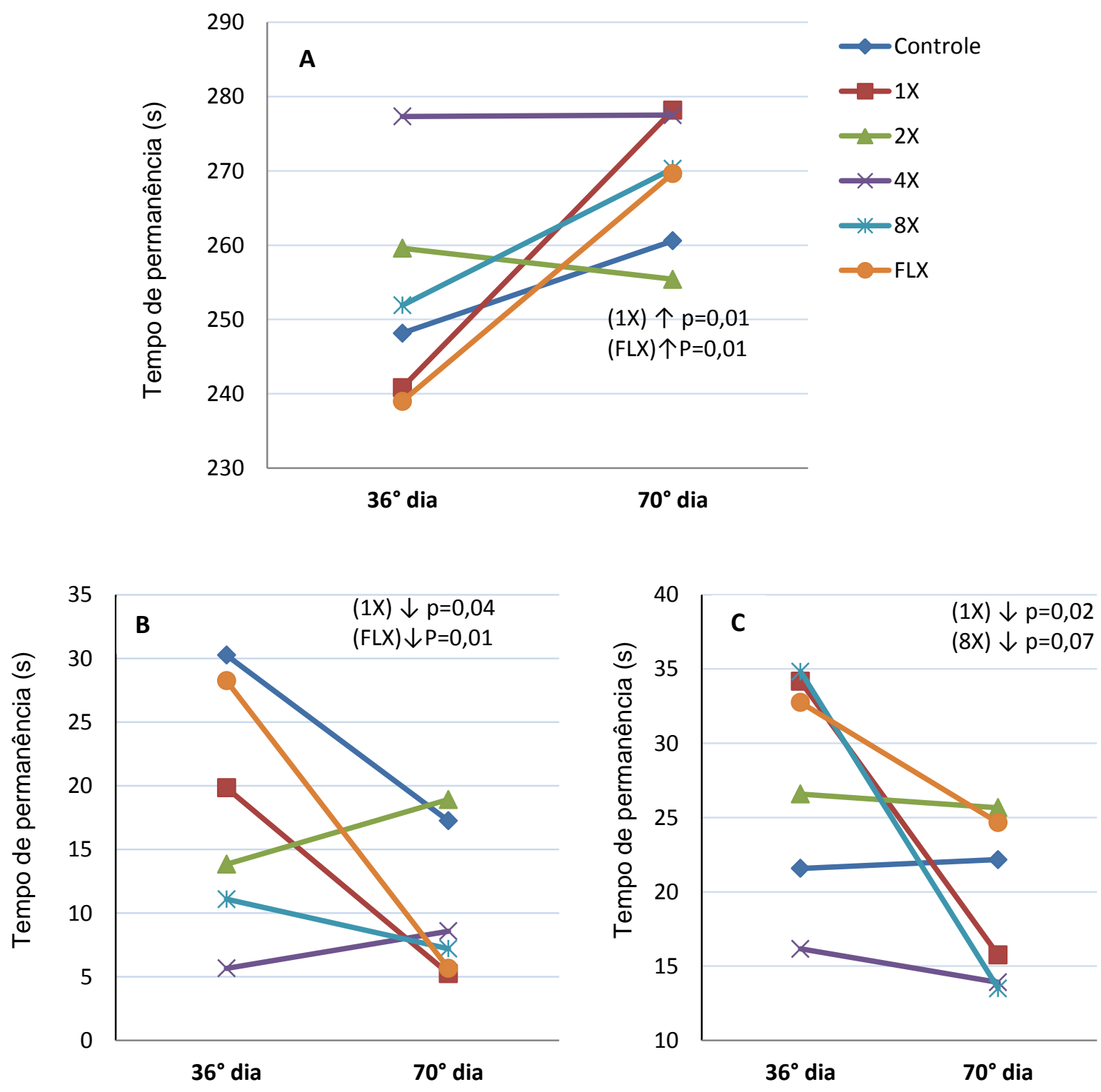

Figura 24. Tempo de permanência no braços fechados (A), braços abertos (B) e no centro (C) dos animais do grupo controle negativo $(n=12)$, controle positivo $(n=12)$ e tratados com ayahuasca (grupos $1 \mathrm{X}, 2 \mathrm{X}, 4 \mathrm{X}, \mathrm{n}=12$; grupo $8 \mathrm{X}, \mathrm{n}=10$ ) durante a segunda avaliação ( $\left.36^{\circ} \mathrm{dia}\right)$ e terceira $\left(70^{\circ} \mathrm{dia}\right)$ no labirinto em cruz elevado; $\uparrow$ indica aumento, $\downarrow$ indica diminuição; mudanças estatisticamente significativas quando $p \leq 0,05$. Resultados analisados pelo Teste T pareado. 


\section{Natação forçada}

No primeiro teste de natação forçada realizada 1 hora após a primeira gavagem não foi observada diferenças significativas entre os grupos nos parâmetros de natação, imobilidade e climbing, embora o grupo tratado com ayahuasca na dose de $2 X$ tenha obtido um escore de natação maior que o grupo controle negativo e um escore de imobilidade menor comparado ao mesmo grupo (Figura 25). A quantidade de bolos fecais foi menor significativamente no grupo de $4 \mathrm{X}$ comparado ao grupo controle positivo (FLX) (Figura 28A).

$\mathrm{Na}$ segunda avaliação comportamental ( $36^{\circ} \mathrm{dia}$ ) observou-se um aumento significativo da natação nos animais tratados com FLX, comparado aos animais do grupo controle negativo e tratados com ayahuasca nas doses de 1X, 2X e 8X. Foi verificada uma diminuição significativa na imobilidade no grupo controle positivo, comparada ao grupo de $1 \mathrm{X}$ e ao controle negativo (Figura 26). O parâmetro de defecação não diferiu estatisticamente entre os grupos (Figura 28B).

$\mathrm{Na}$ terceira avaliação comportamental ocorrida no final do tratamento $\left(70^{\circ} \mathrm{dia}\right)$ observou-se um aumento significativo no climbing nos animais tratados com ayahuasca na dose de $8 \mathrm{X}$ comparado ao grupo de 1X e 4X (Figura 27). Observou-se um aumento significativo na quantidade de bolos fecais no grupo controle positivo comparado ao controle negativo e ao grupo de $2 \mathrm{X}$ (Figura 28C). 


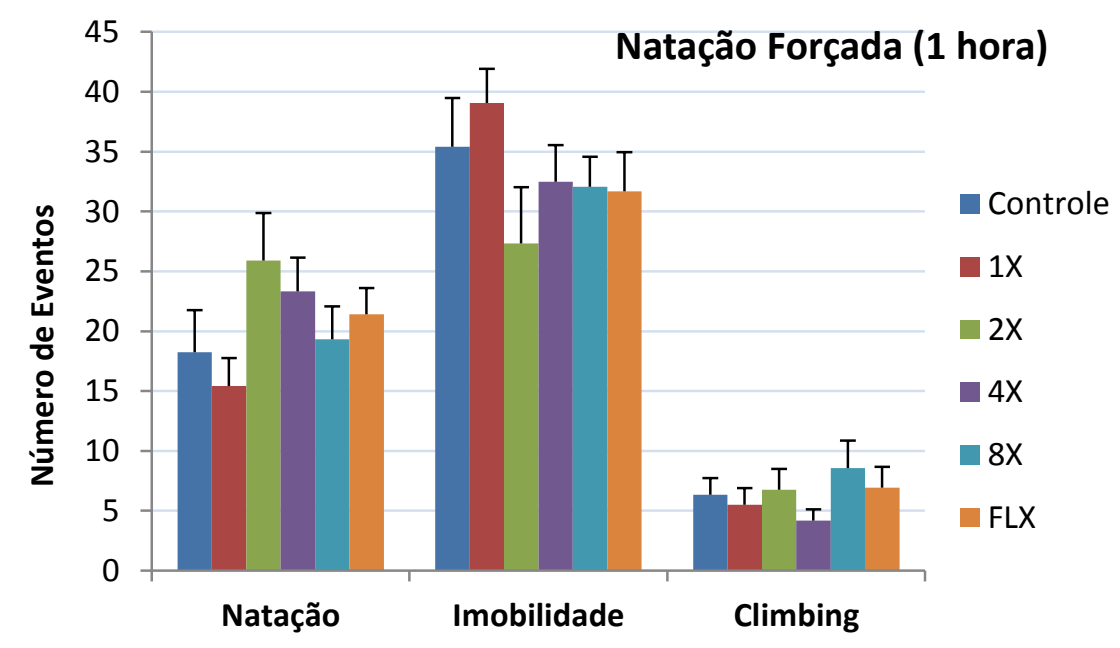

Figura 25. Parâmetros de natação, imobilidade e climbing avaliados no teste de Natação Forçada 1 hora após a primeira gavagem, nos animais do grupo controle negativo, controle positivo e tratados com ayahuasca $(n=12)$. Resultados analisados pela ANOVA com pós-teste de Tukey e Dunnett.

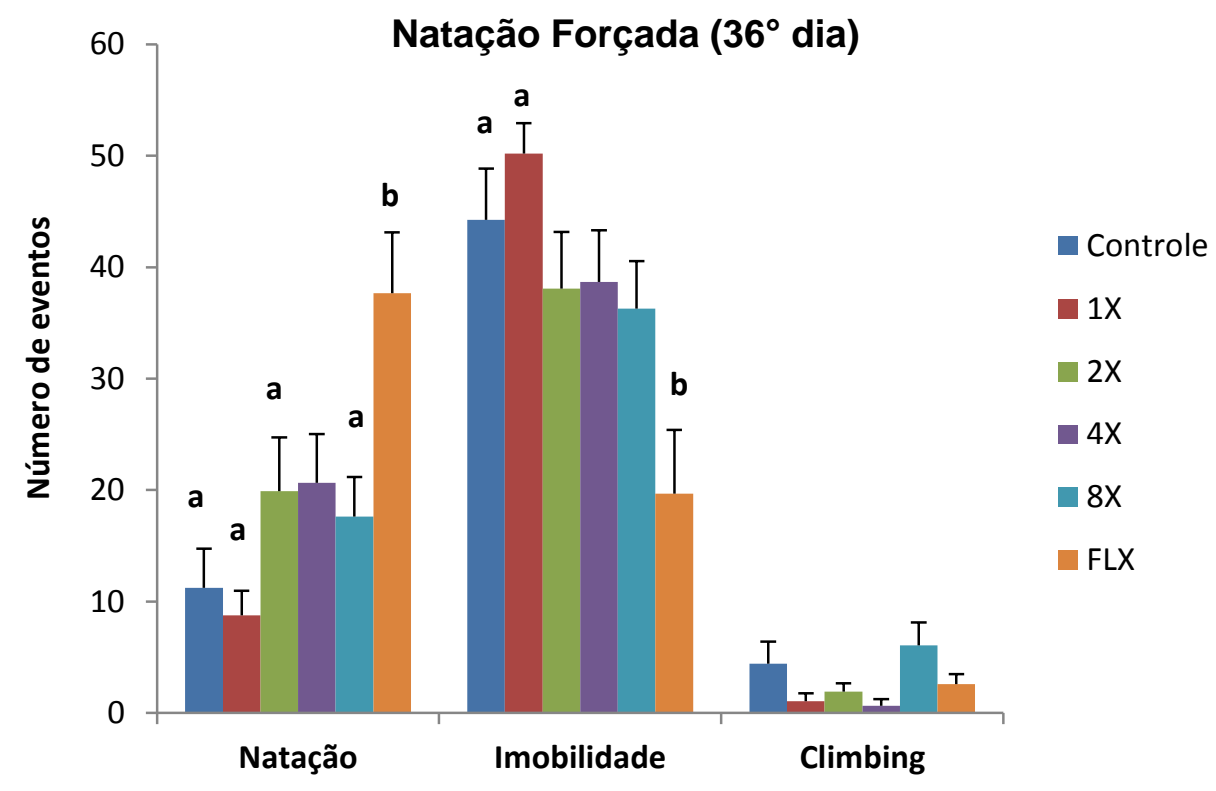

Figura 26. Parâmetros de natação, imobilidade e climbing avaliados no teste de natação forçada no $36^{\circ}$ dia de tratamento, nos animais do grupo controle negativo $(n=12)$, controle positivo $(n=12)$ e tratados com ayahuasca (grupos $1 X, 2 X, 4 X, n=12$; grupo $8 X, n=11)$. Letras diferentes representam diferença significativa. Resultados analisados pela ANOVA com pós-teste de Tukey e Dunnett. 


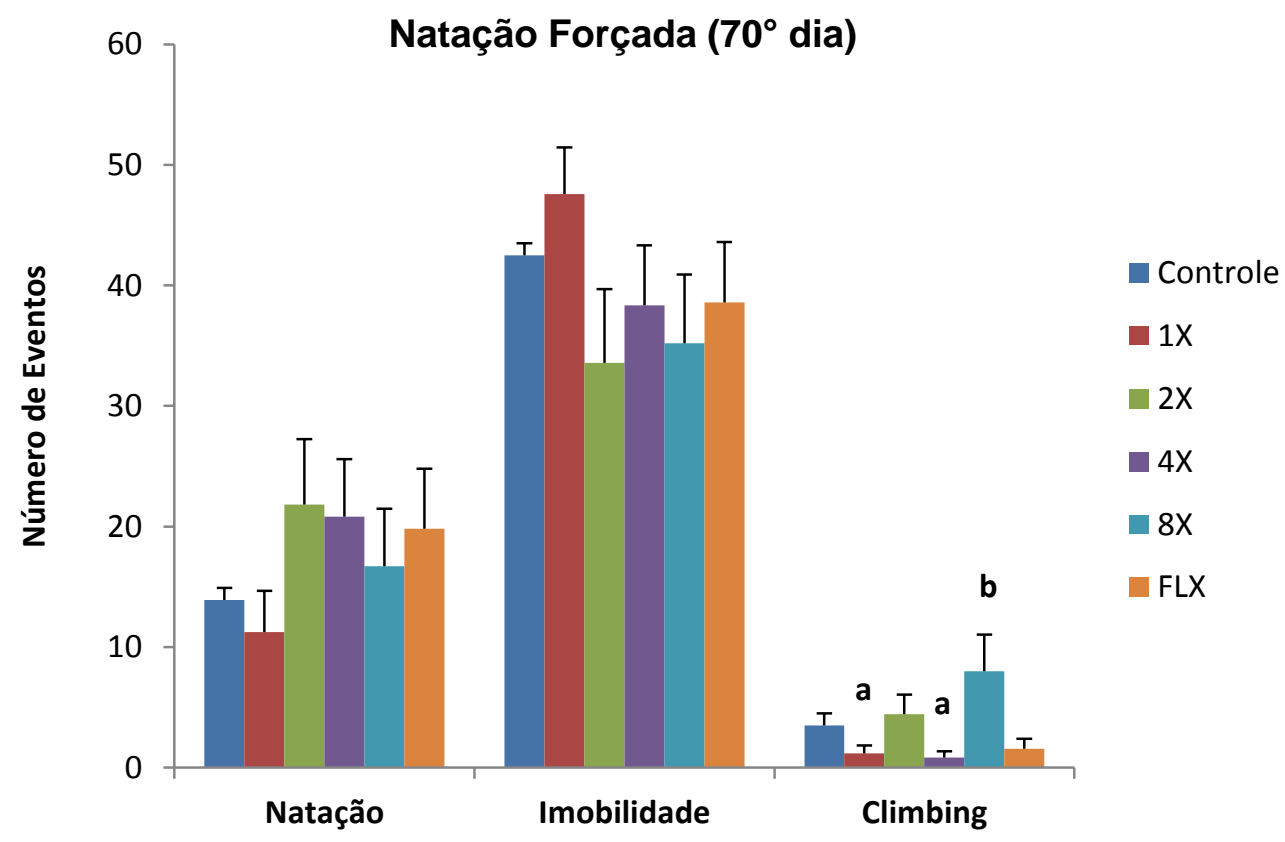

Figura 27. Parâmetros de natação, imobilidade e climbing avaliados no teste de natação forçada no $70^{\circ}$ dia de tratamento, nos animais do grupo controle negativo $(n=12)$, controle positivo $(n=12)$ e tratados com ayahuasca (grupos $1 X, 2 X, 4 X, n=12$; grupo $8 X, n=10$ ). Letras diferentes representam diferença significativa. Resultados analisados pela ANOVA com pós-teste de Tukey e Dunnett. 
A

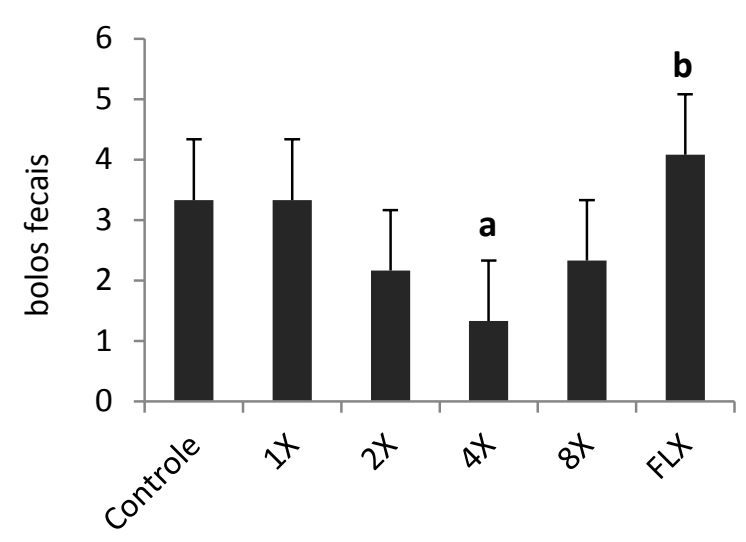

B

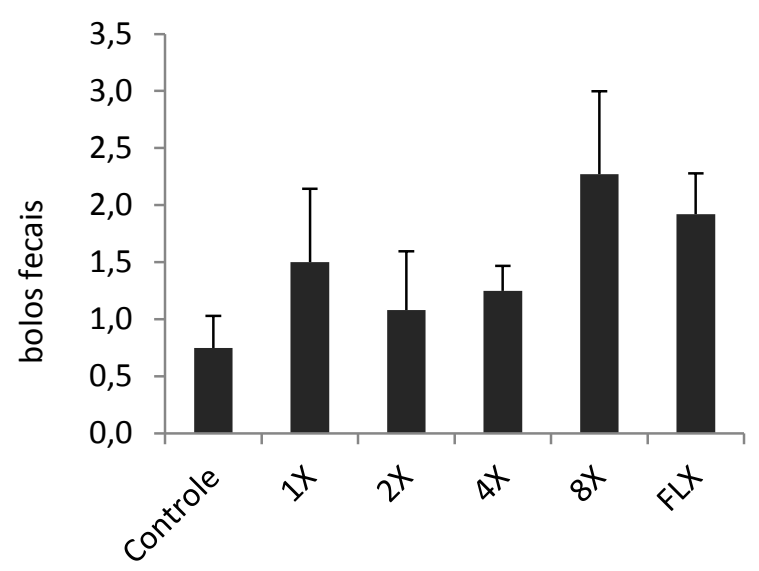

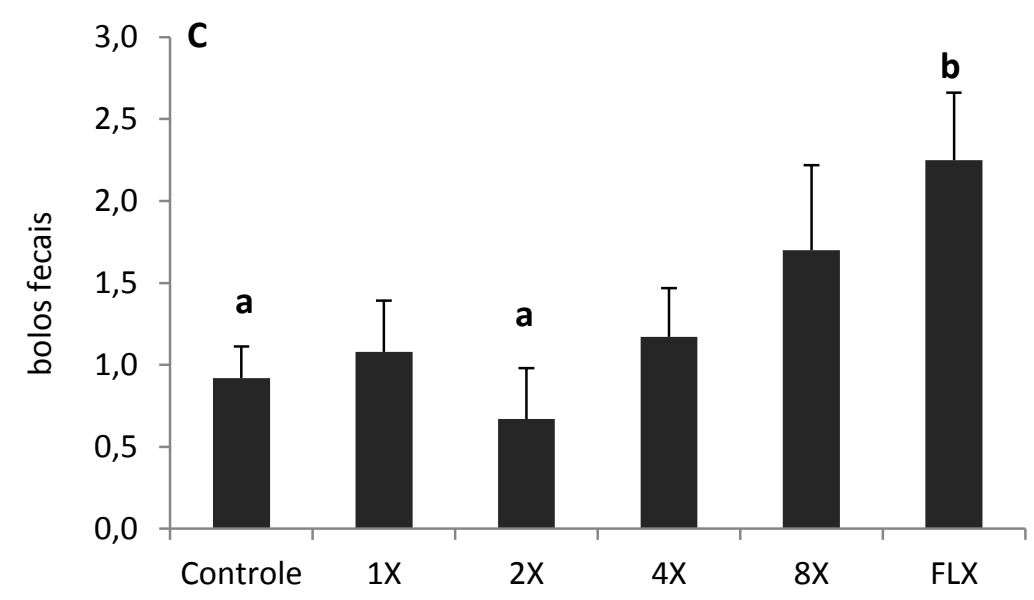

Figura 28. Quantidade de bolos fecais verificada no teste de natação forçada, 1 hora após a primeira gavagem (A), no $36^{\circ}$ dia de tratamento (B) e no $70^{\circ}$ dia (C) nos animais do grupo controle negativo $(n=12)$, controle positivo $(n=12)$ e tratados com ayahuasca (grupos $1 \mathrm{X}, 2 \mathrm{X}, 4 \mathrm{X}, \mathrm{n}=12$; grupo $8 \mathrm{X}, \mathrm{n}=10$ ). Valores expressos em Média \pm SEM. Resultados analisados pela ANOVA com pós-teste de Tukey e Dunnett. Letras diferentes representam diferença significativa.

$\mathrm{Na}$ análise comparativa das duas últimas avaliações da Natação Forçada observou-se uma diminuição significativa da natação e um aumento significativo da imobilidade da segunda avaliação para terceira nos animais tratados com FLX (Figura $29 \mathrm{~A}-\mathrm{B}$ ). Houve um aumento do climbing nos grupos de $2 \mathrm{X}$ e $8 \mathrm{X}$ e uma diminuição nos grupos controle negativo e positivo, porém não significativo estatisticamente (Figura 29C). 
A

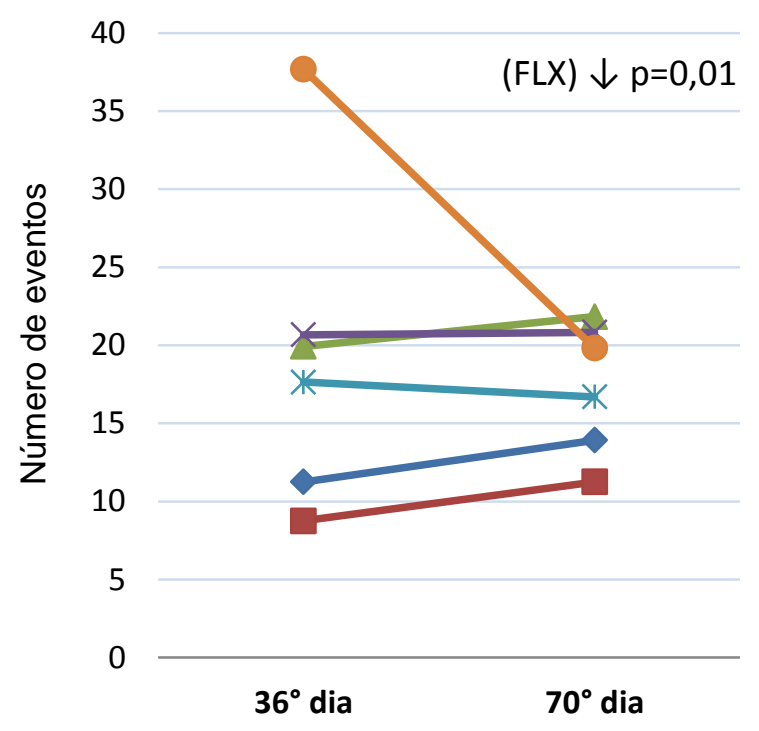

B

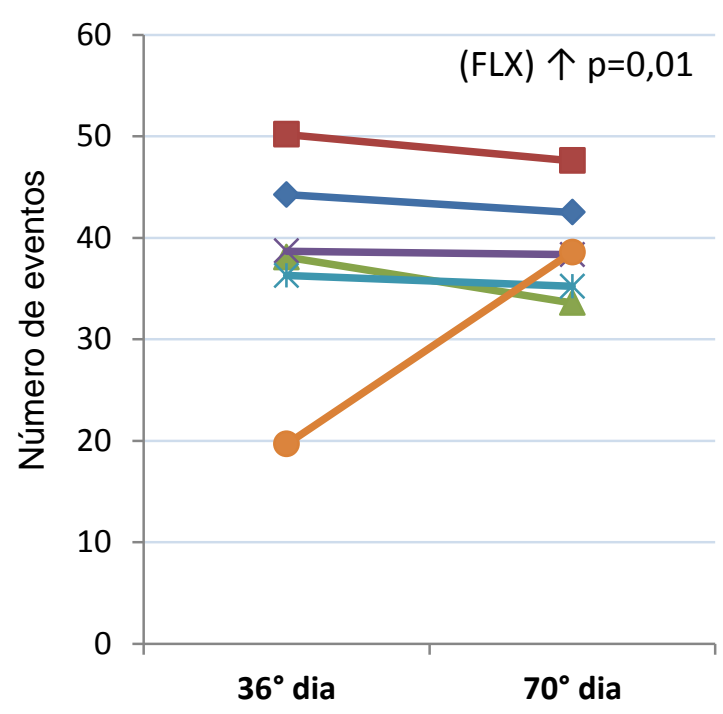

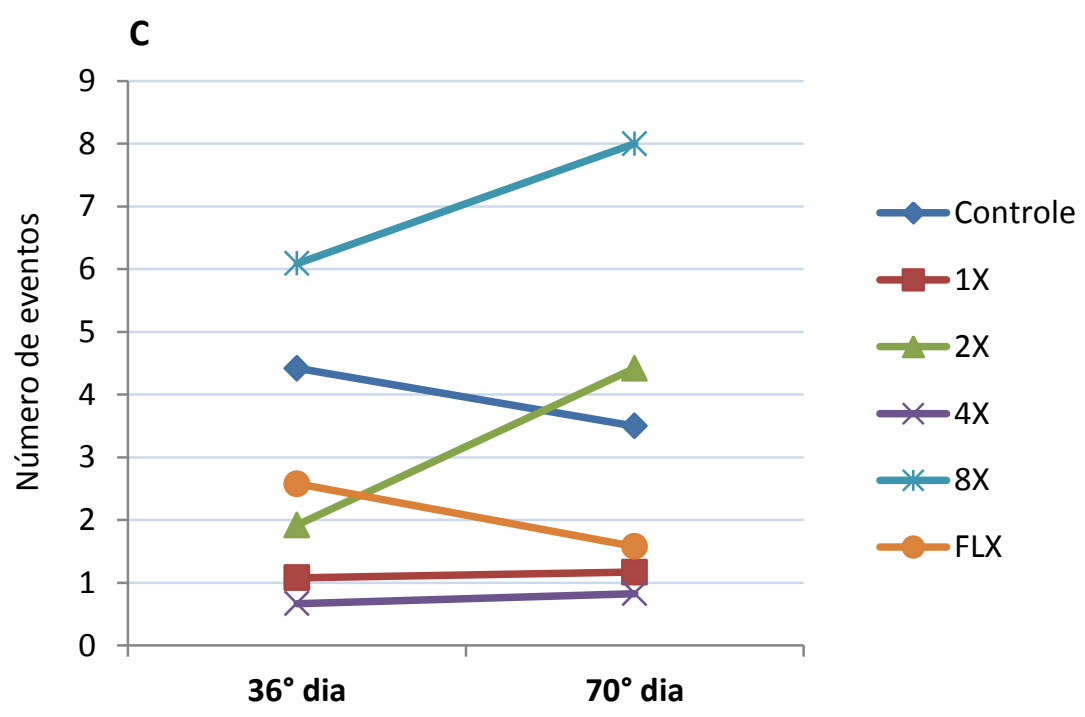

Figura 29. Parâmetros de natação (A), imobilidade (B) e climbing (C) avaliados no teste de natação forçada durante a segunda avaliação $\left(36^{\circ}\right.$ dia $)$ e terceira $\left(70^{\circ} \mathrm{dia}\right)$, dos animais do grupo controle negativo $(n=12)$, controle positivo $(n=12)$ e tratados com ayahuasca (grupos $1 \mathrm{X}, 2 \mathrm{X}, 4 \mathrm{X}, \mathrm{n}=12$; grupo $8 \mathrm{X}, \mathrm{n}=10$ ); $\uparrow$ indica aumento, $\downarrow$ indica diminuição; mudanças estatisticamente significativas quando $p \leq 0,05$. Resultados analisados pelo Teste T pareado. 


\section{DISCUSSÃO}

Os resultados dos efeitos agudos mostraram que os animais tratados com ayahuasca na dose de $4 \mathrm{X}$ percorreram um número significativamente menor de quadrantes no campo aberto comparado ao grupo controle negativo, indicando diminuição da locomoção. Esse grupo também mostrou um aumento significativo da relação da locomoção na área central pela locomoção total comparado ao grupo controle positivo. Segundo Prut and Belzung, (2003), o aumento dessa relação é um indicador de efeito ansiolítico. Esse efeito também pode ser confirmado pela diminuição da atividade locomotora nesse grupo, pois tratamentos ansiolíticos diminuem o estresse induzido e, portanto, inibem o comportamento de exploração no campo aberto (Prut \& Belzung, 2003). Estudo conduzido no nosso grupo por Melo Junior (2014), com o objetivo de investigar os efeitos neurocomportamentais agudos da ayahuasca em ratos Wistar mostrou que os animais (fêmeas e machos) tratados com 15X a dose apresentaram um comportamento exploratório significativamente menor avaliado no campo aberto, 1 hora após a administração, comparado ao grupo controle negativo e ao grupo de $1 \mathrm{X}$. Porém a locomoção na área central do campo não diferiu estatisticamente dos outros grupos. Resultado semelhante foi observado em estudo conduzido com ratas tratadas com ayahuasca nas doses de 30X e 50X (Pic-Taylor et al., 2015).

Os animais do grupo controle positivo foram tratados com fluoxetina $10 \mathrm{mg} / \mathrm{kg}$ por gavagem de forma subaguda, com administrações ocorridas 23,5, 5 e 1 hora antes da primeira avaliação comportamental. Não foram observados comportamentos indicadores de efeito ansiolítico como diminuição da atividade exploratória e aumento da locomoção na área central. No estudo realizado por PicTaylor et al. (2015), ratas tratadas com fluoxetina $20 \mathrm{mg} / \mathrm{kg}$ i.p. subagudamente apresentaram uma atividade exploratória significativamente menor em relação ao grupo controle, porém a locomoção na área central não diferiu. Estudos que tiveram o objetivo de investigar os efeitos da fluoxetina em ratos, administrada em $10 \mathrm{mg} / \mathrm{kg}$ por via intrapenitonial durante 21 dias, não demonstraram a ocorrência de efeito ansiolítico no campo aberto (Durand et al., 1999; Mar et al., 2000). Outros antidepressivos inibidores da recaptação de serotonina, como paroxetina, 
amitripitilina e clomipramina, também não demonstram tal efeito (Prut and Belzung, 2003).

No presente estudo, após 36 dias de tratamento, observou-se que os animais tratados com fluoxetina apresentaram uma relação da locomoção na área central do campo aberto pela locomoção total significativamente maior comparado a todos os outros grupos, sugerindo provável efeito ansiolítico. Porém esse efeito não pode ser confirmado no mesmo teste, pois o mesmo grupo apresentou uma atividade exploratória aumentada, evidenciada pela frequência de elevação significativamente maior comparado aos grupos tratados com ayahuasca nas doses de $2 \mathrm{X}, 4 \mathrm{X}$ e 8X.

Os animais tratados com fluoxetina apresentaram uma diminuição da locomoção na área central do campo aberto da segunda avaliação para terceira. Nos últimos anos tem havido uma crescente utilização de drogas antidepressivas no tratamento de desordens de ansiedade, principalmente as de natureza mais grave, como estresse pós-traumático e agorafobia. Essas drogas atuam sobre os níveis de serotonina e norepinefrina no cérebro, pois agem inibindo a recaptação desses neurotransmissores, revertendo a depleção, a qual se acredita ser a base dos sintomas de ansiedade e depressão (Gray and Hughes, 2015). O teste do campo aberto não é considerado um modelo eficaz de ansiedade patológica, mas é validado para os estudos de desordens de ansiedade generalizada e é útil na identificação do potencial ansiolítico de benzodiazepínicos e ligante dos receptores GABA (Prut and Belzung 2003; Rodgers et al., 1997).

O labirinto em cruz elevado (LCE) é um dos modelos animais mais utilizados no estudo da ansiedade, e se baseia na aversão natural do rato a lugares abertos em níveis mais elevados de exploração em lugares fechados. No LCE, a atividade locomotora é avaliada pelo número de entradas nos braços fechados e a atividade ansiolítica é verificada pelo número de entradas nos braços abertos e o tempo despendido nessas regiões (Hogg, 1996; Rodgers et al., 1997). O aumento do tempo de permanência nos braços fechados é um indicativo de atividade ansiogênica (Rodgers et al., 1997).

Os resultados do presente estudo mostraram que os animais tratados com fluoxetina permaneceram por um tempo significativamente maior nos braços fechados na primeira avaliação comportamental, em relação aos animais tratados 
com ayahuasca na dose de $1 \mathrm{X}$. Isso sugere que no tratamento agudo, o grupo controle positivo esteve sob um nível de ansiedade maior comparado ao grupo tratado 1X. Nesses dois grupos, verificou-se um aumento do tempo despendido nos braços fechados e uma diminuição do tempo de permanência nos braços abertos da segunda avaliação para a terceira, de forma significativa, o que pode indicar um efeito ansiogênico com o passar do tratamento ou uma adaptação comportamental. Alguns estudos evidenciam uma suposta atividade ansiogênica de antidepressivos da classe dos inibidores seletivos de recaptação de serotonina. Na maioria dos estudos, a administração crônica de fluoxetina ocorre diariamente por um período máximo de 21 dias e nenhum efeito sobre a ansiedade é observado no TCA (Prut and Belzung, 2003). Gomes et al. (2009) verificaram que camundongos tratados com dose única de fluoxetina $(5,10,20$ ou $40 \mathrm{mg} / \mathrm{kg}$ i.p) obtiveram um comportamento de evasão inibitória aos braços abertos no LCE, sugerindo atividade ansiolítica. Quando os animais foram tratados de forma crônica com as mesmas doses por 15 dias consecutivos, verificou-se um comportamento contrário do qual a aquisição de evasão inibitória aos braços abertos foi prejudicada, evidenciando um efeito ansiogênico.

$\mathrm{Na}$ análise comparativa das avaliações ocorridas na metade ( $36^{\circ}$ dia) e no final do tratamento $\left(70^{\circ} \mathrm{dia}\right)$ observou-se que os animais tratados com ayahuasca na dose de 2X apresentaram um comportamento diverso aos animais do grupo de $1 \mathrm{X} \mathrm{e}$ ao controle positivo. No grupo de $2 \mathrm{X}$ observou-se uma tendência de aumento do tempo despendido nos braços abertos e uma diminuição do tempo de permanência nos braços fechados da segunda avaliação para a terceira. A potencial atividade ansiolítica verificada na primeira avaliação do teste do Campo Aberto nos animais do grupo de $4 X$ não foi confirmada no LCE, no qual se observou os parâmetros de entrada e tempo de permanência nos braços abertos estatisticamente igual comparado aos outros grupos. Melo Junior (2014) observou que fêmeas tratadas com ayahuasca em dose única de 15X mostraram uma atividade locomotora no LCE menor comparada ao grupo controle e um aumento significativo no tempo de permanência nos braços fechados em relação aos grupos tratados com as doses de 1X e 5X. Pic-Taylor et al. (2015) verificaram resultado semelhante com fêmeas tratadas com ayahuasca em dose única de 30X e 50X. No presente estudo não 
houve diferença nos parâmetros de locomoção e exploração no LCE entre os grupos tratados e controles.

O teste de natação forçada (TNF) é um modelo comportamental animal bastante utilizado no estudo pré-clínico da depressão, sendo seletivo e sensível para medicamentos antidepressivos clinicamente eficazes. Nesse teste, no controle positivo a fluoxetina é administrada de forma subaguda (23,5, 5 e 1 hora antes do teste) e dessa forma é prevista para diminuir o tempo de imobilidade na natação forçada, o que indica efeito antidepressivo (Detke et al., 1995). Em ratos é necessário que ocorra um pré-teste de 15 minutos 24 horas antes do teste para garantir que os animais adotem rapidamente uma postura imóvel durante o teste, permitindo mais facilmente a observação dos efeitos dos compostos testados. Portanto drogas com ação antidepressiva são capazes de reverter à postura de imobilidade no TNF (Slattery and Cryan, 2012).

Os resultados desse estudo mostraram que os parâmetros de natação, imobilidade e climbing nos animais tratados com ayahuasca não diferiram estatisticamente dos grupos controles negativo e positivo na primeira avaliação da Natação Forçada. A administração de fluoxetina (10 mg/kg via gavagem) também não foi suficiente para reduzir a imobilidade. Resultado semelhante foi observado por Detke e Lucki (1997), no qual não foram observados diminuição da imobilidade e aumento da natação em ratos tratados subagudamente com fluoxetina nas doses de 2 e $5 \mathrm{mg} / \mathrm{kg}$ i.p. Pic-Taylor et al. (2015) observaram que o tratamento com fluoxetina (20 mg/kg i.p) também não foi capaz de diminuir a postura de imobilidade em ratas submetidas ao teste de Natação Forçada. No mesmo estudo, verificou-se que ratas tratadas com ayahuasca em dose única de $30 \mathrm{X}$ e $50 \mathrm{X}$ obtiveram um escore de imobilidade menor e de natação maior comparado aos grupos controle negativo e positivo, indicando um potencial antidepressivo da bebida. Melo Junior (2014) verificou que ratos tratados com dose única de $1 \mathrm{X}$ e $5 \mathrm{X}$ obtiveram um comportamento mais ativo na água, evidenciado por um aumento significativo do tempo de climbing. Em fêmeas, a dose única de $15 \mathrm{X}$ foi capaz de diminuir o tempo de imobilidade e aumentar o tempo de natação na avaliação realizada 2 horas após a administração. Os resultados dos estudos realizados por Melo Junior (2014) e PicTaylor, (2015) sugerem um potencial efeito antidepressivo da ayahuasca em doses altas logo depois da administração (efeito agudo). 
No teste de natação forçada ocorrido no $36^{\circ}$ dia verificou-se que o tratamento crônico com fluoxetina, mesmo ocorrendo em dias alternados, foi capaz de produzir efeito antidepressivo, evidenciado pela diminuição da imobilidade e aumento da natação, efeito este não verificado nos animais tratados com ayahuasca nas mesmas condições. No entanto, o efeito antidepressivo observado na metade do tratamento no grupo controle positivo não foi verificado no final do tratamento $\left(70^{\circ}\right.$ dia), visto que os parâmetros de natação, imobilidade e climbing nesse grupo não diferiram estatisticamente dos outros grupos. Na terceira avaliação da natação forçada foi observado que os animais tratados com ayahuasca na dose de $8 \mathrm{X}$ obtiveram um escore de climbing significativamente maior que o grupo de $1 \mathrm{X}$ e $4 \mathrm{X}$, sem alteração da imobilidade, mostrando um comportamento mais ativo na água.

É evidente que a ação dos antidepressivos na reversão do déficit serotoninérgico não mostra ser eficiente de forma aguda ou subaguda no homem, mas exige-se um tempo de tratamento de 2-4 semanas para atingir um efeito positivo (Slattery and Cryan, 2012). Os resultados do presente estudo mostraram que a fluoxetina produziu efeitos positivos como aumento da natação e diminuição da imobilidade no teste de natação forçada quando administrada cronicamente até 0 $36^{\circ}$ dia, em dias alternados, e que a dose de $10 \mathrm{mg} / \mathrm{kg}$ foi ineficiente quando administrada subagudamente. Interessantemente, esse efeito positivo verificado cronicamente não perdurou até o final do tratamento, no qual foi observada uma diminuição significativa na natação e um aumento significativo na imobilidade da segunda avaliação para terceira. Detke e Lucki (1997) também observaram que alguns antidepressivos não mantêm sua ação no teste de natação forçada após um período longo de administração.

O intervalo de tempo necessário para a eficácia terapêutica dos antidepressivos pode ser explicado pela existência de mecanismos auto-reguladores nos neurônios monoaminérgicos pré-sinápticos. A administração aguda de um agente antidepressivo promove uma diminuição na frequência de descarga neuronal, concomitantemente com uma diminuição na síntese e liberação de serotonina e norepinefrina. Isso sugere que o aumento da concentração de neurotransmissor na fenda sináptica induzido pelo antidepressivo promove uma inibição da descarga neuronal por retroalimentação através dos auto-receptores. Com isso, a exposição inicial de um agente antidepressivo pode não aumentar de 
forma significativa a sinalização pós-sináptica. Por outro lado a exposição prolongada produz um aumento na neurotransmissão, pois induz a uma infraregulação dos próprios auto-receptores inibitórios, ou seja, provoca uma redução no número de auto-receptores, exercendo, dessa forma, pouco efeito na inibição da síntese e liberação dos neurotransmissores (Golan, 2009).

Durante o tratamento crônico é comum o relato de perda da eficácia do antidepressivo pelos pacientes, provavelmente por perda do efeito da droga, tolerância farmacológica, acúmulo de metabólicos, perda da resposta placebo inicial, dentre outras razões. Algumas estratégias são previstas para superarem esse problema, como ajuste da dose dentro da janela terapêutica, ou mudança da classe do fármaco (Souza, 1999). No presente estudo, os animais tratados com fluoxetina apresentaram uma diminuição da natação e um aumento significativo da imobilidade da segunda avaliação para a terceira no teste de natação forçada, esse resultado pode indicar que a droga perdeu a eficácia após determinado tempo ou que os animais adquiriram tolerância farmacológica. $O$ aumento da taxa de defecação nos animais tratados com fluoxetina na terceira avaliação indica que essa mudança na natação e imobilidade ocorrida ao longo do tratamento não pode ser atribuída a uma adaptação comportamental, uma vez que a defecação é considerada uma boa medida de reatividade emocional em situações adversas (Armario et al., 1988). Os animais tratados com ayahuasca nas doses de $2 \mathrm{X}$ e $8 \mathrm{X}$ apresentaram um aumento do climbing da segunda avaliação para a terceira. Embora ocorrido de forma não significativa, esse resultado indica uma suposta tendência desses animais a apresentarem um comportamento mais ativo na água com o decorrer do tratamento, comportamento este considerado uma medida válida de ação antidepressiva (Armario et al., 1988; Detke et al., 1995).

\section{CONCLUSÕES}

O tratamento agudo de ayahuasca na dose de $4 \mathrm{X}$ em ratos machos Wistar mostrou ter um potencial efeito ansiolítico inicialmente avaliado do teste do campo aberto, porém esse efeito não pode ser confirmado no teste do labirinto em cruz elevado. O tratamento crônico de ayahuasca nas doses selecionadas, em dias alternados, não foi suficiente para provocar um efeito ansiolítico e antidepressivo em 
ratos. Contudo os animais tratados com a dose de $2 \mathrm{X}$ tenderam a permanecer mais tempo nos braços abertos e menos tempo nos braços fechados no LCE ao longo do tratamento, podendo ser um indicativo de atividade ansiolítica. Além disso, esses animais também apresentaram uma tendência de aumento do climbing na natação forçada ao longo do tratamento. Os animais tratados com a dose de $8 \mathrm{X}$ obtiveram um comportamento ativo na água significativamente maior após o tratamento crônico com tendência de aumento com o decorrer do tratamento, o que pode sugerir provável ação antidepressiva.

O tratamento crônico com fluoxetina $(10 \mathrm{mg} / \mathrm{kg}$ via gavagem, em dias alternados), no grupo controle positivo foi capaz de provocar uma ação antidepressiva nos animais até a metade do tratamento (36 dias). Porém a persistência do tratamento, nessas condições, até $\circ 70^{\circ}$ dia não manifestou continuidade de ação antidepressiva, sugerindo provável perda da eficácia da droga ou aquisição de tolerância farmacológica pelos animais. Neste grupo, as avaliações do teste do labirinto em cruz elevado mostraram um aumento do tempo despendido nos braços fechados e uma diminuição do tempo de permanência nos braços abertos, ao longo do tratamento, sugerindo haver uma adaptação comportamental ou uma provável ação ansiogênica. Efeito este também observado no grupo tratado com ayahuasca na dose de $1 \mathrm{X}$.

Os resultados obtidos por este e outros estudos realizados pelo nosso grupo de pesquisa indicam a necessidade da condução de um estudo crônico, de 14 ou 21 dias, com doses baixas (até $2 \mathrm{X}$ a dose usual) para confirmar o potencial antidepressivo e ansiolítico da ayahuasca. 


\section{AVALIAÇÃO DA TOXICIDADE REPRODUTIVA MASCULINA DA AYAHUASCA}

No total foram utilizados 60 ratos machos Wistar tratados a cada dois dias por 70 dias, divididos em 5 grupos de 12 animais, sendo um grupo controle e 4 grupos tratados com ayahuasca (1, 2, 4 e 8X a dose usual) (ver Materiais e Métodos, pg 34 a 37). O grupo controle positivo tratado com fluoxetina, incluído nas avaliações comportamentais, não foi avaliado quanto aos aspectos de toxicidade reprodutiva.

\section{Análise da motilidade espermática}

Durante as necropsias dos animais do estudo, o conteúdo do ducto deferente foi expelido por difusão em $1 \mathrm{~mL}$ de Dulbecco's Modified Eagle Medium (DMEM) (GIBCO) previamente aquecido a $34^{\circ} \mathrm{C}$ para análise da motilidade espermática, sem ultrapassar o tempo máximo de 10 minutos após a eutanásia. Foram inseridos 100 $\mu \mathrm{L}$ dessa solução em um hemacitômetro (câmara de Neubauer) e as leituras foram realizadas em microscópio óptico (Leica Galen III), com aumento de 400X.

Foram analisados 50 espermatozoides por animal e quantificado o percentual de progressivos (espermatozoides com progressão rápida, ou seja, que percorrem vários quadrantes da câmara), e não progressivos (espermatozoides sem progressão ou imóveis) (Seed et al., 1996).

\section{Contagem total de espermatozoides, produção espermática diária e tempo de trânsito espermático.}

O testículo direito de cada animal foi perfurado em uma das extremidades para retirada da túnica albugínea e o parênquima homogeneizado em $10 \mathrm{~mL}$ de Triton X-100 0,05\% para a obtenção da contagem total de espermatozoides ( $\mathrm{n}^{\circ} \mathrm{X}$ $10^{6}$ ), produção espermática diária e tempo de trânsito espermático (dias). A cauda do epidídimo direito de cada animal foi picotada em placa de Petri e o mesmo procedimento de homogeneização foi feito para a obtenção da reserva espermática. 
Cada amostra foi homogeneizada em Ultra-Turrax IKA ${ }^{\circledR} \mathrm{T} 10$ basic durante 1 minuto, utilizando $1 / 6$ da capacidade de velocidade do homogeneizador. Para as contagens realizou-se uma diluição de 1:10 do homogeneizado em Triton X-100 0,05\% e posteriormente $100 \mu \mathrm{l}$ da diluição foi inserida na Câmara de Neubauer. Foram contadas as espermátides (testículo) e espermatozoides (epidídimo) resistentes à homogeneização em cinco campos da câmara (Strader et al., 1996). A leitura foi realizada em duas amostras diferentes para cada animal e feita a média. Utilizou-se microscópio óptico (Zeiss Primo Star) em aumento de 400X.

A produção espermática diária foi obtida dividindo o número de espermátides resistentes no testículo por 6,1 dias (Blazak et al., 1985; Robb et al., 1978). Este tempo representa o número de dias no ciclo seminífero em que as espermátides maduras estão presentes (Kempinas et al., 1998). Espermátides maduras de rato em estágio 17 a 19 representam $48 \%$ de um ciclo do epitélio seminífero que tem a duração de 12,75 dias (Robb et al, 1978).

O tempo de trânsito espermático foi obtido dividindo o número de espermatozoides na cauda do epidídimo pela produção espermática diária (Robb et al, 1978).

\section{Análise da morfologia espermática}

A cauda do epidídimo esquerdo de cada animal foi picotada em $2 \mathrm{~mL}$ de tampão fosfato-salino (PBS) (1,38 g de fosfato de sódio monobásico; $6,96 \mathrm{~g}$ de fosfato de sódio dibásico; 7,2 g de $\mathrm{NaCl}$, diluídos em $1 \mathrm{~L}$ de água destilada, $\mathrm{pH} 7,4$ ) para a coleta de espermatozoides. Foi retirado $1 \mathrm{~mL}$ da solução resultante, que foi diluído em $5 \mathrm{~mL}$ de PBS e armazenado em geladeira por até 10 dias para posterior análise. Foram preparadas duas lâminas por animal pelo método de esfregaço, as lâminas secas à temperatura ambiente, fixadas com metanol por 10 minutos $\mathrm{e}$ coradas com Eosina 1\% por 30 - 45 minutos (Wyrobek \& Bruce, 1975).

Foram analisados 200 espermatozoides por animal, em ensaio cego, e quantificado o percentual de espermatozoides normais (Figura 30a) e anormais (Figura 30b a 30g). Foram avaliadas anormalidades na cabeça, na cauda e espermatozoides com múltiplas anormalidades (Figura 30h) (Sciences, Wellcome, and Sequani, 2000; Sharma \& Singh, 2010). 

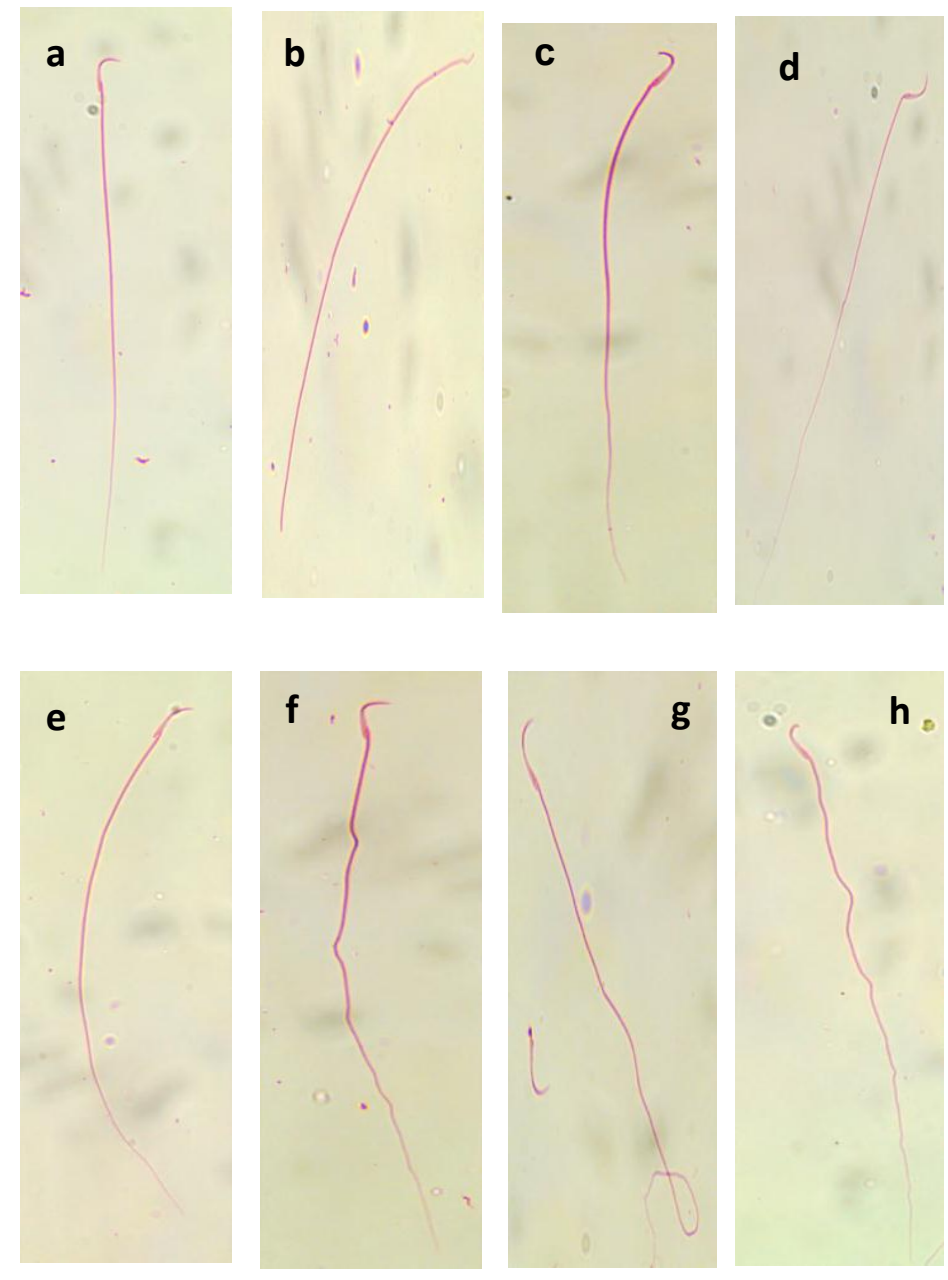

Figura 30. Parâmetros morfológicos avaliados: a. espermatozoide normal, b. espermatozoide sem cabeça, c. cabeça achatada, d. pescoço dobrado, e. cabeça com curvatura reduzida, f. cauda curvada, g. cauda enrolada, h. múltiplas anormalidades.

\section{Processamento histológico do testículo e epidídimo}

O testículo esquerdo de cada animal foi pré-fixado em Bouin $(750 \mathrm{~mL}$ de ácido pícrico, solução aquosa; $250 \mathrm{~mL}$ de formalina $37-40 \%$; $50 \mathrm{~mL}$ de ácido acético glacial) durante 3 horas a $4^{\circ} \mathrm{C}$, cortados ao meio de forma transversal e mantidos por mais 4 horas na mesma temperatura. Os segmentos cabeça/corpo dos epidídimos de cada animal também foram fixados em Bouin durante 7 horas a $4^{\circ} \mathrm{C}$ para análise histopatológica. 
Após esse período, os órgãos foram lavados em álcool 50\% "overnight" em temperatura ambiente para retirada do excesso do fixador, imersos em álcool $70 \% \mathrm{e}$ mantidos até o procedimento histológico.

O processamento histológico incluiu a etapa de desidratação, diafanização e inclusão em parafina. Os órgãos foram desidratados em solução crescente de etanol a $80 \%$ e $90 \%$ durante 1 hora cada e três banhos de álcool 100\% de 1 hora cada. $\mathrm{Na}$ etapa de diafanização, os órgãos foram imersos em uma solução de álcool e xilol 1:1 durante 45 minutos, seguido de três banhos de xilol 100\% de 45 minutos cada. Posteriormente as amostras foram submetidas a três banhos de parafina purificada em estufa a $60^{\circ} \mathrm{C}$ durante 1 hora cada. Após essa etapa o material foi incluso em blocos de parafina utilizando moldes de metal e em seguida refrigerados.

Foram obtidos cortes não consecutivos (a cada dois ou três cortes) de $5 \mu \mathrm{m}$ de espessura utilizando micrótomo (LEICA). As lâminas foram desparafinadas em estufa a $60^{\circ} \mathrm{C}$ e submetidas a três banhos de xilol, de 2 a 5 minutos. Em seguida foram imersas em soluções decrescentes de álcool 100\%, 90\%, 80\% e 70\% (1,5 minutos cada), coradas com hematoxilina e eosina (H\&E), seguida de imersão em soluções crescentes de álcool (70\% até $100 \%)$. Por fim, as lâminas foram aderidas em lamínula utilizando verniz transparente. Três lâminas de cada animal foram analisadas por uma patologista em ensaio cego utilizando microscópio de luz em aumento de 400X.

\section{Análise Histopatológica}

Para a histopatologia do epidídimo, seções longitudinais do órgão foram analisadas quanto à densidade espermática no interior do túbulo e classificadas como hipoespermia moderada $(+++)$, hipoespermia discreta $(++)$, e densidade espermática normal (+). A presença de alterações no epidídimo e testículo tais como esfoliação de células germinativas, vacuolização tubular, infiltrados inflamatório, granulomas, necrose, edema e túbulos com redução do diâmetro e desorganização celular também foi investigada (Lanning, 2002). No testículo, além da verificação de alterações histopatológicas, 10 túbulos seminíferos em cada lâmina (3 lâminas por animal) foram analisados quanto à presença de espermatogênese completa, pelo 
método de Escore de Biópsia Tubular de Johnsen's (JTBS). Esse método foi originalmente proposto para avaliar a espermatogênese em testículo humano (Johnsen's, 1970), mas atualmente também é utilizado para avalia-la em testículo de ratos (Kanter, 2010). O método consiste em classificar a espermatogênese em escores de 1 a 10 de acordo com o critério mostrado no Quadro 1 (Johnsen, 1970; Kanter, 2010). Para cada animal, o escore foi estimado como a média observada em 10 túbulos das 3 lâminas analisadas ( $n=30$ ) (MJTBS).

Quadro 1. Escore de Biópsia Tubular de Johnsen's

\begin{tabular}{|c|l|}
\hline Escore & Classificação \\
\hline $\mathbf{1 0}$ & $\begin{array}{l}\text { Espermatogênese completa, com muitos espermatozoides } \\
\text { (espermatozoides com cabeça pequena), epitélio germinativo organizado } \\
\text { com uma espessura regular e um lúmen aberto. }\end{array}$ \\
\hline $\mathbf{9}$ & $\begin{array}{l}\text { Muitos espermatozoides presentes, porém um epitélio germinativo } \\
\text { desorganizado com desprendimento acentuado ou obstrução do lúmen e } \\
\text { presença de muitas espermátides tardias. }\end{array}$ \\
\hline $\mathbf{8}$ & $\begin{array}{l}\text { Alguns espermatozoides presentes na seção (<5 - 10) e poucas } \\
\text { espermátides tardias. }\end{array}$ \\
\hline $\mathbf{7}$ & $\begin{array}{l}\text { Nenhum espermatozoide, mas muitas espermátides presentes, sem } \\
\text { espermátides tardias. }\end{array}$ \\
\hline $\mathbf{6}$ & $\begin{array}{l}\text { Nenhum espermatozoide e somente poucas espermátides presentes }(<5 \\
-10) .\end{array}$ \\
\hline $\mathbf{5}$ & $\begin{array}{l}\text { Ausência de espermatozoides e espermátides, porém presença de } \\
\text { muitos espermatócitos. }\end{array}$ \\
\hline $\mathbf{4}$ & $\begin{array}{l}\text { Somente poucos espermatócitos primários }(<5) \text { e nenhuma espermátide } \\
\text { ou espermatozoide presente. }\end{array}$ \\
\hline $\mathbf{3}$ & Espermatogônias são as únicas células germinativas presentes. \\
\hline $\mathbf{2}$ & $\begin{array}{l}\text { Ausência de células da linhagem germinativa, apenas presença de } \\
\text { células de Sertoli. } \\
\text { Nenhuma célula na seção tubular. }\end{array}$ \\
\hline $\mathbf{1}$ & \\
\hline
\end{tabular}




\section{Análise bioquímica e hormonal}

Foi realizada a dosagem das enzimas amilase e lipase para avaliação da função pancreática, bilirrubina total, direta e indireta para avaliação funcional hepática, e creatinina e ureia para verificação da função renal. Além disso, foram dosadas as enzimas transaminase glutâmico oxalacética (TGO) e transaminase glutâmico pirúvica (TGP) para avaliação da função hepatobiliar e pancreática, e os níveis de triglicérides para a avaliação da metabolização lipídica.

Para a análise hormonal foram quantificados os níveis de testosterona total e dos hormônios luteinizante $(\mathrm{LH})$ e folículo estimulante (FSH) por quimioluminescência. As análises foram realizadas pelo Instituto Sabin.

\section{Análise estatística}

A análise estatística da morfologia espermática foi realizada pelo teste de Kruskal-Wallis e as demais foram feitas pela ANOVA Fatorial (oneway) com pósteste de Tukey e Dunnett. A análise histopatológica do testículo e epidídimo foi realizada pelo teste do Qui-quadrado. As análises foram realizadas no programa IBM SPSS Statistics version 20, e os resultados foram considerados estatisticamente significativos quando $p \leq 0,05$.

\section{RESULTADOS}

\section{Toxicidade crônica}

Os animais tratados com ayahuasca nas doses de $1 \mathrm{X}, 2 \mathrm{X}$ e $4 \mathrm{X}$ não apresentaram sinais clínicos como piloereção ou tremores ao longo do tratamento. Porém a maioria dos animais tratados com a dose de 8X apresentaram sinais evidentes de estresse e vocalização constante momentos antes das administrações.

A Tabela 4 mostra o ganho de peso total dos animais ao final do tratamento com ayahuasca, o consumo médio de ração medido a cada três dias e o peso corpóreo ao final do tratamento. Foi observada uma diminuição significativa no 
ganho de peso corpóreo e no consumo de ração nos animais tratados com ayahuasca nas doses de $4 \mathrm{X}$ e $8 \mathrm{X}$ em relação ao grupo controle. O peso corpóreo ao final do tratamento foi significativamente menor nos animais tratados com ayahuasca na dose de $8 \mathrm{X}$ em relação ao grupo controle e ao grupo de $2 \mathrm{X}$.

Tabela 4. Ganho de peso total, consumo de ração e peso corpóreo ao final do tratamento dos animais do grupo controle e tratados com ayahuasca nas doses de 1X, 2X, 4X e $8 \mathrm{X}$ durante 70 dias alternados (Média \pm SEM).

\begin{tabular}{lccccc}
\hline & $\begin{array}{c}\text { Controle } \\
(\mathbf{n = 1 2})\end{array}$ & $\begin{array}{c}\mathbf{1 X} \\
\mathbf{( n = 1 2 )}\end{array}$ & $\begin{array}{c}\mathbf{2 X} \\
\mathbf{( n = 1 2 )}\end{array}$ & $\begin{array}{c}\mathbf{4 X} \\
\mathbf{( n = 1 2 )}\end{array}$ & $\begin{array}{c}\mathbf{8 X} \\
(\mathbf{n = 1 0})\end{array}$ \\
\hline $\begin{array}{l}\text { Ganho de } \\
\text { peso total, g }\end{array}$ & $204,1 \pm 7,9^{\mathrm{a}}$ & $194,8 \pm 7,6^{\mathrm{a}}$ & $197,5 \pm 8,9^{\mathrm{a}}$ & $167,3 \pm 9,2^{\mathrm{b}^{*}}$ & $158,5 \pm 7,5^{\mathrm{b}^{* *}}$ \\
$\begin{array}{l}\text { Consumo de } \\
\text { ração, g }\end{array}$ & $72,1 \pm 0,7^{\mathrm{a}}$ & $70,9 \pm 1,4^{\mathrm{a}}$ & $74,6 \pm 1,1^{\mathrm{a}}$ & $66,9 \pm 0,7^{\mathrm{b}}$ & $64,2 \pm 1,0^{\mathrm{b}}$ \\
$\begin{array}{l}\text { Peso } \\
\text { corpóreo ao } \\
\text { final do } \\
\text { tratamento, }\end{array}$ & $405,4 \pm 11,9^{\mathrm{a}}$ & $401,1 \pm 13,7$ & $409,7 \pm 11,4^{\mathrm{a}}$ & $381,1 \pm 12,3$ & $355,3 \pm 10,5^{\mathrm{b}}$ \\
\hline
\end{tabular}

Letras diferentes: Diferenças significativas entre os grupos $(p \leq 0,05)$; símbolo: Comparação com o grupo controle, ${ }^{*}$ indica $p<0,05$, ${ }^{* *}$ indica $p \leq 0,01$. Resultados analisados pela ANOVA com pós teste de Tukey e Dunnett.

A Tabela 5 mostra o peso relativo dos órgãos dos animais dos grupos controle e tratados. Foi verificado um aumento do peso relativo dos epidídimos dos animais do grupo de $4 \mathrm{X}$ em relação ao grupo de $8 \mathrm{X}$, e uma diminuição do peso relativo da vesícula seminal dos animais tratados com a dose de $2 \mathrm{X}$ com relação ao controle e ao grupo $8 \mathrm{X}$. Foi observado um aumento do peso relativo do cérebro do grupo de $8 \mathrm{X}$ em relação ao controle e o grupo $2 \mathrm{X}$ e do peso relativo do estômago dos animais do grupo $8 \mathrm{X}$ em relação ao controle. Não foram observadas alterações macroscópicas nos órgãos avaliados. 
Tabela 5. Peso relativo dos órgãos dos animais do grupo controle e tratados com ayahuasca nas doses de $1 \mathrm{X}, 2 \mathrm{X}, 4 \mathrm{X}$ e $8 \mathrm{X}$ (Média \pm SEM). (\% em relação ao peso corpóreo no final do tratamento)

\begin{tabular}{lccccc}
\hline Peso Relativo & $\begin{array}{c}\text { Controle } \\
(\mathbf{n = 1 2})\end{array}$ & $\begin{array}{c}\mathbf{1 X} \\
(\mathbf{n = 1 2})\end{array}$ & $\begin{array}{c}\mathbf{2 X} \\
(\mathbf{n}=12)\end{array}$ & $\begin{array}{c}\mathbf{4 X} \\
(\mathbf{n}=\mathbf{1 2})\end{array}$ & $\begin{array}{c}\mathbf{8 X} \\
(\mathbf{n = 1 0})\end{array}$ \\
\hline Órgãos Reprodutivos, \% & & & & \\
Testículo direito & $0.48 \pm 0.06$ & $0.47 \pm 0.03$ & $0.47 \pm 0.04$ & $0.50 \pm 0.04$ & $0.49 \pm 0.04$ \\
Testículo esquerdo & $0.48 \pm 0.06$ & $0.46 \pm 0.04$ & $0.48 \pm 0.04$ & $0.51 \pm 0.04$ & $0.49 \pm 0.04$ \\
Testículo, ambos & $0.48 \pm 0.06$ & $0.47 \pm 0.03$ & $0.47 \pm 0.04$ & $0.51 \pm 0.04$ & $0.49 \pm 0.04$ \\
Epidídimo direito & $0.20 \pm 0.05$ & $0.21 \pm 0.06$ & $0.22 \pm 0.06$ & $0.25 \pm 0.06^{\mathrm{a}}$ & $0.18 \pm 0.05^{\mathrm{b}}$ \\
Epidídimo esquerdo & $0.20 \pm 0.04$ & $0.22 \pm 0,05$ & $0.22 \pm 0.08$ & $0.24 \pm 0.05$ & $0.18 \pm 0.05$ \\
Epidídimo, ambos & $0.20 \pm 0.04$ & $0.21 \pm 0.05$ & $0.22 \pm 0.07$ & $0.25 \pm 0,05^{\mathrm{a}}$ & $0.18 \pm 0.05^{\mathrm{b}}$ \\
Próstata & $0.20 \pm 0.09$ & $0.23 \pm 0.06$ & $0.20 \pm 0.06$ & $0.23 \pm 0.07$ & $0.17 \pm 0.03$ \\
Vesícula Seminal & $0.37 \pm 0.06^{\mathrm{a}}$ & $0.34 \pm 0.08$ & $0.29 \pm 0.05^{\mathrm{b}}$ & $0.34 \pm 0.05$ & $0.40 \pm 0.09^{\mathrm{a}}$ \\
Demais órgãos, \% & & & & & \\
Fígado & $3.56 \pm 0.33$ & $3.47 \pm 0.20$ & $3.43 \pm 0.25$ & $3.49 \pm 0.20$ & $3.52 \pm 0.26$ \\
Baço & $0.20 \pm 0.04$ & $0.19 \pm 0.01$ & $0.18 \pm 0.03$ & $0.18 \pm 0.02$ & $0.18 \pm 0.03$ \\
Rim Direito & $0.35 \pm 0.02$ & $0.34 \pm 0.02$ & $0.36 \pm 0.04$ & $0.35 \pm 0.01$ & $0.37 \pm 0.04$ \\
Rim Esquerdo & $0.34 \pm 0.02$ & $0.32 \pm 0.02$ & $0.34 \pm 0.03$ & $0.34 \pm 0.02$ & $0.35 \pm 0.04$ \\
Estômago & $0.46 \pm 0.06^{\mathrm{a}}$ & $0.50 \pm 0.02$ & $0.48 \pm 0.03$ & $0.51 \pm 0.02$ & $0.52 \pm 0.04^{\mathrm{b}}$ \\
Coração & $0.52 \pm 0.06^{\mathrm{a}}$ & $0.53 \pm 0.06$ & $0.51 \pm 0.06^{\mathrm{a}}$ & $0.55 \pm 0.04$ & $0.59 \pm 0.05^{\mathrm{b}}$ \\
\hline Letras & $0.32 \pm 0.03$ & $0.32 \pm 0.04$ & $0.31 \pm 0.02$ & $0.33 \pm 0.02$ & $0.33 \pm 0.03$ \\
\hline
\end{tabular}

Letras diferentes: Diferença significativa entre os grupos $(p \leq 0,05)$. Resultados analisados pela ANOVA com pós-teste de Tukey e Dunnett.

Foi verificado uma diminuição significativa do peso médio absoluto dos testículos no grupo de $8 \mathrm{X}$ em comparação com o grupo controle e os grupos tratados nas doses de $2 \mathrm{X}$ e $4 \mathrm{X}$. Esse mesmo grupo mostrou uma diminuição do peso médio dos epidídimos em relação aos grupos de $2 \mathrm{X}$ e $4 \mathrm{X}$ e uma diminuição do peso da próstata em relação ao grupo de $1 \mathrm{X}$. Os animais tratados com ayahuasca 
na dose de $8 X$ também tiveram uma diminuição significativa do peso do baço em relação ao grupo controle (Tabela 6).

Tabela 6. Peso absoluto dos órgãos dos animais do grupo controle e tratados com ayahuasca nas doses de 1X, 2X, 4X e 8X (Média \pm SEM).

\begin{tabular}{cccccc}
\hline Peso absoluto & $\begin{array}{c}\text { Controle } \\
(n=12)\end{array}$ & $\begin{array}{c}1 X \\
(n=12)\end{array}$ & $\begin{array}{c}2 X \\
(n=12)\end{array}$ & $\begin{array}{c}4 X \\
(n=12)\end{array}$ & $\begin{array}{c}8 X \\
(n=10)\end{array}$ \\
\hline
\end{tabular}

\section{Órgãos Reprodutivos, $g$}

\begin{tabular}{|c|c|c|c|c|c|}
\hline Testículo, ambos & $1,93 \pm 0,07^{\mathrm{a}}$ & $1,86 \pm 0,04$ & $1,93 \pm 0,04^{\mathrm{a}}$ & $1,93 \pm 0,05^{\mathrm{a}}$ & $1,73 \pm 0,05^{b}$ \\
\hline Epidídimo, ambos & $0,82 \pm 0,05$ & $0,85 \pm 0,05$ & $0,92 \pm 0,09^{a}$ & $0,93 \pm 0,05^{a}$ & $0,65 \pm 0,05^{b}$ \\
\hline Próstata & $0,80 \pm 0,11$ & $0,92 \pm 0,09^{a}$ & $0,82 \pm 0,07$ & $0,87 \pm 0,07$ & $0,59 \pm 0,04^{b}$ \\
\hline Vesícula Seminal & $1,48 \pm 0.06^{a}$ & $1,32 \pm 0,07$ & $1,19 \pm 0,05^{b}$ & $1,30 \pm 0,05$ & $1,42 \pm$ \\
\hline
\end{tabular}

\section{Demais órgãos, $g$}

Fígado

$$
14,4 \pm 0,5 \quad 13,9 \pm 0,5 \quad 14,1 \pm 0,6 \quad 13,3 \pm 0,5 \quad 12,5 \pm 0,4
$$

Baço

$0,79 \pm 0,04^{\mathrm{a}} \quad 0,75 \pm 0,03 \quad 0,76 \pm 0,04 \quad 0,68 \pm 0,03 \quad 0,65 \pm 0,01^{\mathrm{b}}$

Rins

$1,39 \pm 0,04 \quad 1,32 \pm 0,04 \quad 1,43 \pm 0,07 \quad 1,30 \pm 0,04 \quad 1,27 \pm 0,07$

Estômago

$1,84 \pm 0,08 \quad 1,97 \pm 0,06 \quad 1,96 \pm 0,09 \quad 1,92 \pm 0,06 \quad 1,85 \pm 0,04$

Cérebro

$2,10 \pm 0,03 \quad 2,10 \pm 0,02 \quad 2,08 \pm 0,06 \quad 2,08 \pm 0,03 \quad 2,07 \pm 0,03$

Coração

$1,30 \pm 0,04 \quad 1,26 \pm 0,04 \quad 1,28 \pm 0,03 \quad 1,25 \pm 0,04 \quad 1,17 \pm 0,04$

Letras diferentes: Diferença significativa entre os grupos $(p \leq 0,05)$. Resultados analisados pela ANOVA com pós-teste de Tukey e Dunnett.

As análises bioquímicas realizadas para a averiguação do comprometimento das funções hepática, pancreática, renal e de metabolização lipídica não indicaram alterações significativas nas dosagens enzimáticas dos animais tratados com ayahuasca em relação ao grupo controle (Tabela 7).

A análise hormonal para verificação das dosagens de LH e FSH (Tabela 8) não mostrou alterações significativas nos grupos tratados com ayahuasca em relação ao grupo controle. Porém, foi observado um aumento significativo das dosagens de testosterona total dos animais tratados com ayahuasca na dose de $4 \mathrm{X}$ comparando com o grupo controle $(p=0,03)$ e com o grupo de $8 X(p=0,05)$. 
Tabela 7. Dosagens enzimáticas dos animais do grupo controle e tratados com ayahuasca. Valores expressos em Média \pm SEM.

\begin{tabular}{|c|c|c|c|c|c|}
\hline & Controle & $1 X$ & $2 X$ & $4 X$ & $8 X$ \\
\hline Amilase (U/L) & $\begin{array}{l}1806,1 \pm \\
211,6\end{array}$ & $\begin{array}{l}2182,3 \pm \\
163,7\end{array}$ & $\begin{array}{l}2320,4 \pm \\
206,9\end{array}$ & $\begin{array}{l}1873,6 \pm \\
251,8\end{array}$ & $\begin{array}{l}1999,8 \pm \\
292,6\end{array}$ \\
\hline $\begin{array}{l}\text { Bilirrubina Total } \\
\text { (mg/dL) }\end{array}$ & $0,03 \pm 0,00$ & $0,04 \pm 0,00$ & $0,03 \pm 0,00$ & $0,03 \pm 0,00$ & $0,04 \pm 0,00$ \\
\hline $\begin{array}{l}\text { Bilirrubina dreta } \\
\text { (mg/dL) }\end{array}$ & $0,01 \pm 0,00$ & $0,01 \pm 0,00$ & $0,02 \pm 0,00$ & $0,02 \pm 0,00$ & $0,02 \pm 0,00$ \\
\hline $\begin{array}{l}\text { Bilirrubina } \\
\text { indireta }(\mathrm{mg} / \mathrm{dL})\end{array}$ & $0,02 \pm 0,00$ & $0,02 \pm 0,00$ & $0,02 \pm 0,00$ & $0,01 \pm 0,00$ & $0,02 \pm 0,00$ \\
\hline $\begin{array}{l}\text { Creatinina } \\
(\mathrm{mg} / \mathrm{dL})\end{array}$ & $0,17 \pm 0,02$ & $0,23 \pm 0,02$ & $0,20 \pm 0,02$ & $0,18 \pm 0,01$ & $0,17 \pm 0,02$ \\
\hline Lipase (UI) & $8,17 \pm 0,96$ & $8,33 \pm 0,74$ & $9,25 \pm 0,86$ & $8,25 \pm 1,03$ & $8,78 \pm 1,30$ \\
\hline TGO (UI) & $107,3 \pm 21,4$ & $118,1 \pm 22,1$ & $101,6 \pm 16,4$ & $79,8 \pm 11,2$ & $176,0 \pm 69,8$ \\
\hline TGP (UI) & $32,5 \pm 3,8$ & $38,3 \pm 3,3$ & $35,6 \pm 3,3$ & $29,9 \pm 3,3$ & $38,9 \pm 6,7$ \\
\hline $\begin{array}{l}\text { Triglicerídeos } \\
\text { (mg/dL) }\end{array}$ & $238,2 \pm 29,0$ & $223,8 \pm 14,2$ & $269,1 \pm 26,2$ & $206,2 \pm 18,5$ & $199,0 \pm 28,3$ \\
\hline Ureia (mg/dL) & $45,7 \pm 3,8$ & $53,3 \pm 2,5$ & $51,8 \pm 2,9$ & $45,9 \pm 2,9$ & $46,4 \pm 4,5$ \\
\hline
\end{tabular}

Resultados analisados pela ANOVA com pós-teste de Tukey e Dunnett.

Tabela 8. Níveis hormonais de testosterona, hormônio luteinizante (LH) e folículo estimulante $(\mathrm{FSH})$ dos animais do grupo controle e tratados com ayahuasca. Valores expressos em média \pm SEM.

\begin{tabular}{lccccc}
\hline $\begin{array}{l}\text { Níveis } \\
\text { Hormonais }\end{array}$ & $\begin{array}{c}\text { Controle } \\
(\mathbf{n = 1 2})\end{array}$ & $\begin{array}{c}\mathbf{1 X} \\
\mathbf{( n = 1 2 )}\end{array}$ & $\begin{array}{c}\mathbf{2 X} \\
\mathbf{( n = 1 2 )}\end{array}$ & $\begin{array}{c}\mathbf{4 X} \\
(\mathbf{n}=12)\end{array}$ & $\begin{array}{c}\mathbf{8 X} \\
(\mathbf{n = 1 0})\end{array}$ \\
\hline $\begin{array}{l}\text { Testosterona } \\
\text { total, (ng/dL) }\end{array}$ & $178,1 \pm 322^{\mathrm{a}}$ & $355,4 \pm 87,5$ & $310,2 \pm 52,7$ & $511,4 \pm 120,0^{\mathrm{b}}$ & $192,4 \pm 60,6^{\mathrm{a}}$ \\
$\mathrm{LH}(\mathrm{mlU} / \mathrm{mL})$ & $0,08 \pm 0,01$ & $0,08 \pm 0,01$ & $0,07 \pm 0,00$ & $0,07 \pm 0,00$ & $0,07 \pm 0,00$ \\
$\begin{array}{l}\mathrm{FSH} \\
(\mathrm{mlU} / \mathrm{mL})\end{array}$ & $0,66 \pm 0,11$ & $0,37 \pm 0,04$ & $0,48 \pm 0,07$ & $0,50 \pm 0,06$ & $0,56 \pm 0,09$ \\
\hline
\end{tabular}

Letras diferentes: Diferenças significativas $(p \leq 0,05)$. Resultados analisados pela ANOVA com pós-teste de Tukey e Dunnett. 


\section{Motilidade e morfologia espermática}

O percentual de espermatozoides progressivos (motilidade espermática) e morfologicamente normais (normalidade espermática) está mostrado na Figura 31. Em média, mais de $75 \%$ dos espermatozoides apresentaram motilidade normal (progressiva), sem diferença significativa entre os grupos do estudo. Embora todos os grupos tratados apresentaram percentual de espermatozoides morfologicamente normais menor que o controle, chegando a $46.9 \%$ no grupo $4 \mathrm{X}$, essa diminuição não foi estatisticamente significativa (Figura 31).
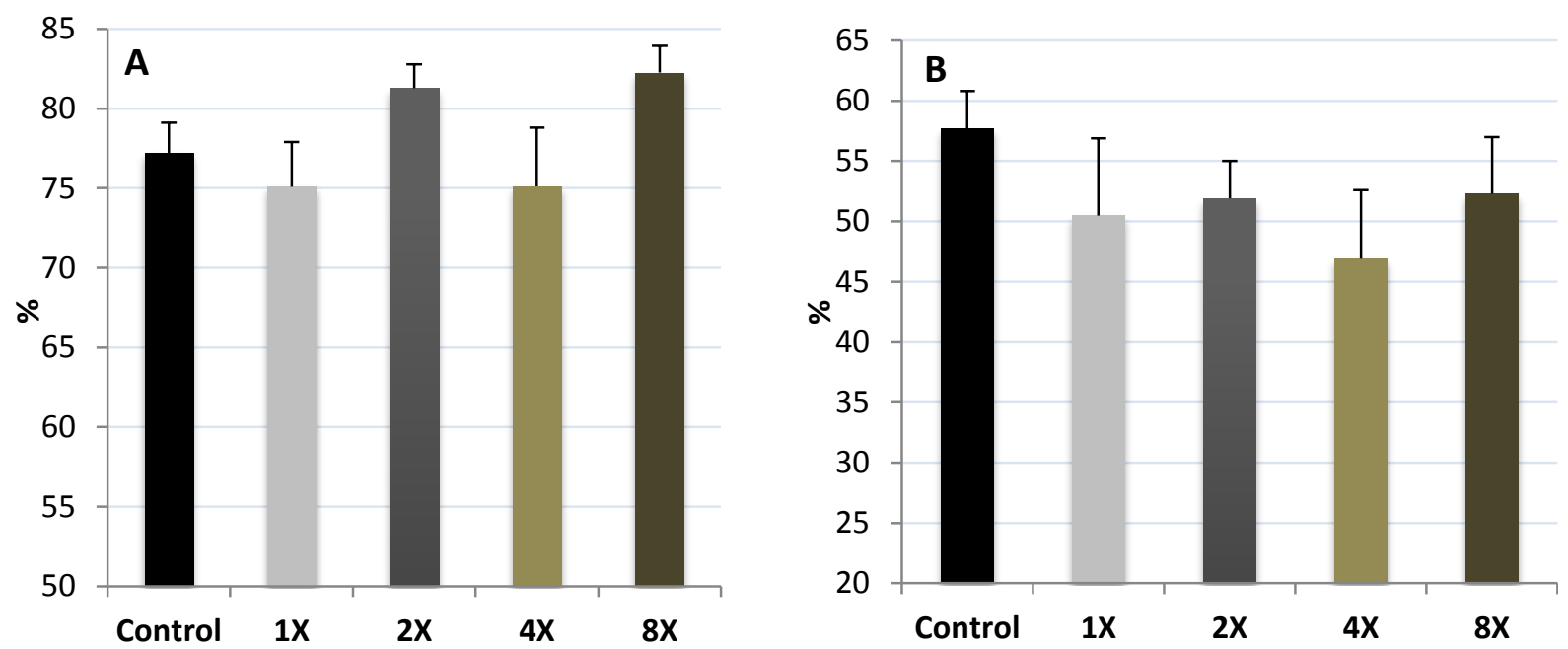

Figura 31. Percentual de espermatozoides progressivos (A) e morfologicamente normais $(B)$ dos animais do grupo controle $(n=12)$ e tratados com ayahuasca (grupos $1 \mathrm{X}, 2 \mathrm{X}, 4 \mathrm{X}, \mathrm{n}=12$; grupo $8 \mathrm{X}, \mathrm{n}=10$ ) (Média $\pm \mathrm{SEM}$ ). Resultados analisados pelo teste de Kruskal-Wallis.

A Tabela 9 mostra o percentual de espermatozoides anormais encontrados nos animais dos grupos experimentais. Não houve diferenças significativas entre os animais tratados e o grupo controle, porém houve um aumento do percentual de espermatozoides com a cauda curvada nos grupos tratados com as doses de $2 \mathrm{X} \mathrm{e}$ $4 \mathrm{X}$ em relação ao grupo de $1 \mathrm{X}$. Esse tipo de anormalidade pode ocorrer devido à alteração na osmolaridade das células durante o tempo de armazenamento em geladeira (até 10 dias). Além disso, houve um aumento do percentual de espermatozoides com a cabeça achatada nos animais do grupo de $8 \mathrm{X}$ em relação ao grupo de 2X. O percentual de espermatozoides sem cabeça foi alto mesmo nos animais do grupo controle. É possível que esta anormalidade seja consequência do procedimento de esfregaço realizado na preparação das lâminas. 
Tabela 9. Percentual de espermatozoides anormais dos animais do grupo controle e tratados com ayahuasca. Valores expressos em média \pm SEM.

\begin{tabular}{|c|c|c|c|c|c|}
\hline $\begin{array}{l}\text { Anormalidade } \\
\text { Espermática, } \\
\%\end{array}$ & $\begin{array}{c}\text { Controle } \\
(n=12)\end{array}$ & $\begin{array}{c}1 X \\
(n=12)\end{array}$ & $\begin{array}{c}2 X \\
(n=12)\end{array}$ & $\begin{array}{c}4 X \\
(n=12)\end{array}$ & $\begin{array}{c}8 X \\
(n=10)\end{array}$ \\
\hline Sem cabeça & $18,2 \pm 3,7$ & $28,7 \pm 7,6$ & $14,3 \pm 2,3$ & $17,2 \pm 4,2$ & $17,3 \pm 1,7$ \\
\hline $\begin{array}{l}\text { Cabeça } \\
\text { achatada }\end{array}$ & $0,3 \pm 0,1$ & $0,3 \pm 0,1$ & $0,1 \pm 0,1^{a}$ & $0,3 \pm 0,1$ & $0,9 \pm 0,4^{b}$ \\
\hline $\begin{array}{l}\text { Cabeça com } \\
\text { curvatura } \\
\text { reduzida }\end{array}$ & $1,4 \pm 0,5$ & $0,7 \pm 0,2$ & $0,7 \pm 0,3$ & $1,3 \pm 0,2$ & $1,2 \pm 0,5$ \\
\hline $\begin{array}{l}\text { Pescoço } \\
\text { dobrado }\end{array}$ & $1,4 \pm 0,3$ & $2,1 \pm 0,7$ & $2,0 \pm 0,8$ & $0,8 \pm 0,3$ & $0,9 \pm 0,3$ \\
\hline Cauda curvada & $18,7 \pm 3,6$ & $14,6 \pm 2,8^{\mathrm{a}}$ & $27,3 \pm 3,4^{b}$ & $29,1 \pm 3,7^{b}$ & $24,2 \pm 4,3$ \\
\hline Cauda enrolada & $0,2 \pm 0,1$ & $0,7 \pm 0,3$ & $0,7 \pm 0,2$ & $0,7 \pm 0,3$ & $0,7 \pm 0,4$ \\
\hline $\begin{array}{l}\text { Múltiplas } \\
\text { anormalidades }\end{array}$ & $0,0 \pm 0,0$ & $0,2 \pm 0,2$ & $0,2 \pm 0,1$ & $0,4 \pm 0,2$ & $0,2 \pm 0,1$ \\
\hline Total & $41,9 \pm 3,0$ & $49,9 \pm 6,6$ & $48,1 \pm 3,1$ & $53,1 \pm 5,8$ & $47,7 \pm 4,7$ \\
\hline
\end{tabular}

Letras diferentes: Diferenças significativas $(p \leq 0,05)$. Resultados analisados pelo teste de Kruskal-Wallis.

\section{Produção espermática diária, reserva espermática na cauda do epidídimo e tempo de trânsito espermático.}

Não foram observadas alterações significativas na contagem total de espermátides no testículo entre os grupos. A produção espermática diária nos animais tratados com a dose de $8 \mathrm{X}$ foi menor comparando com o grupo controle $\mathrm{e}$ outros grupos tratados, porém essa diminuição não foi estatisticamente significativa $(\mathrm{p}=0,36)$ (Figura 32A).

Foi observada uma diminuição significativa tanto da reserva espermática na cauda do epidídimo quanto no tempo de trânsito espermático dos animais tratados com a dose de $4 \mathrm{X}$ em relação ao grupo controle e ao grupo de $8 \mathrm{X}$ (Figura 32B e $32 \mathrm{C})$. 

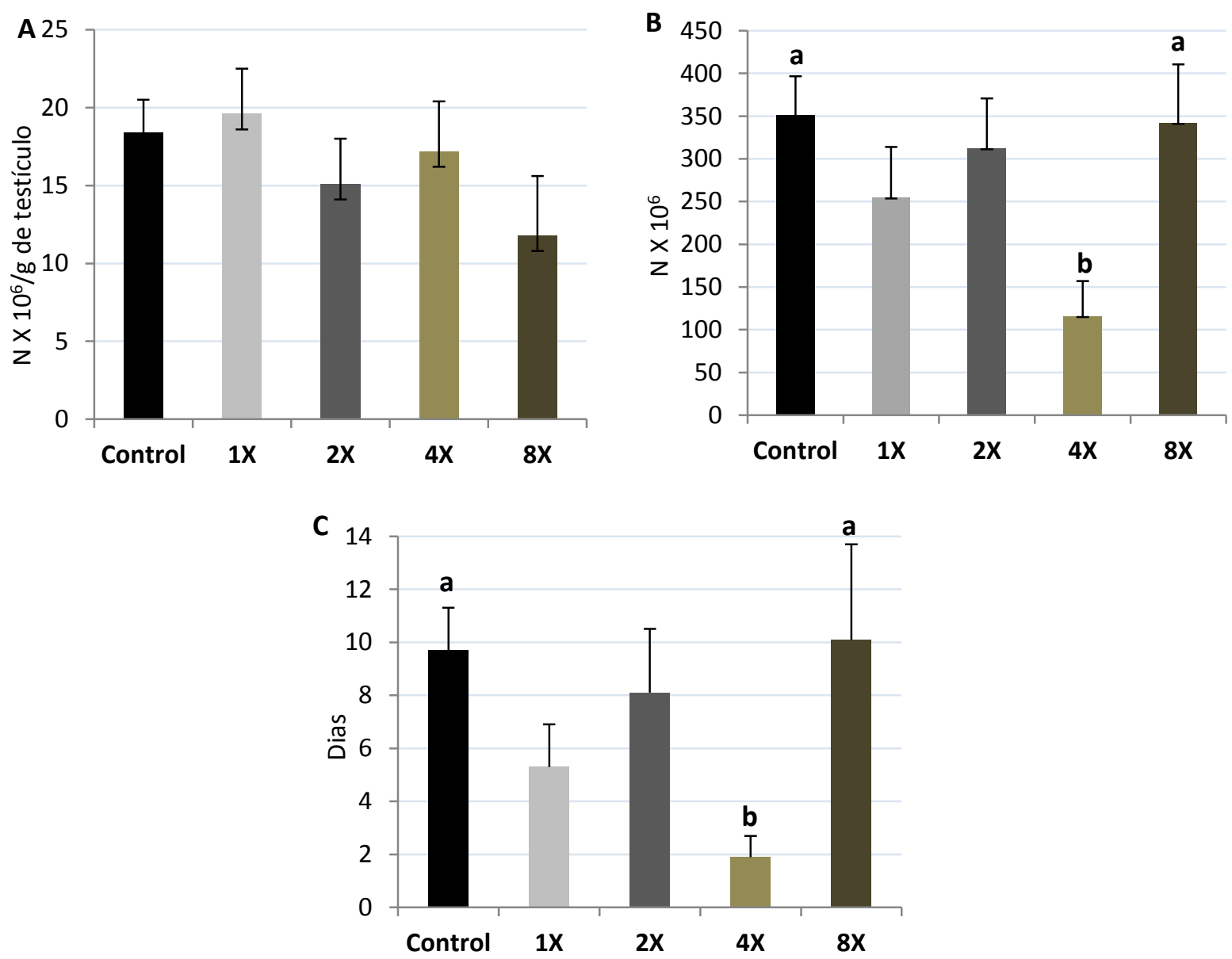

Figura 32. Produção espermática diária (A); reserva espermática na cauda do epidídimo (B) e tempo de trânsito espermático (C) dos animais do grupo controle $(n=12)$ e tratados com ayahuasca (grupos $1 X, 2 X, 4 X, n=12$; grupo $8 X, n=10$ ). Valores expressos em média \pm SEM $(p<0,05)$. Resultados analisados pela ANOVA com pós-teste de Tukey e Dunnett.

\section{Histologia do testículo e epidídimo}

A Tabela 10 mostra o escore médio obtido na avaliação da espermatogênese (MJTBS) e a incidência de alterações histopatológicas no testículo em cada grupo. Não foi verificada alteração significativa no escore médio MJTBS obtido entre os grupos, embora tenha havido uma pequena diminuição no grupo de $4 X(p=0,27)$. Vacuolização tubular foi o evento mais frequente, estando presente em todos os grupos do estudo (Figura 33C). Edema testicular, esfoliação de células germinativas (Figura 33B) e alterações nos túbulos seminíferos ocorreram mais no grupo $4 \mathrm{X}$ 
(Figura 33D), enquanto os animais deste grupo apresentaram menos necrose. Nenhuma alteração histológica verificada nos testículos apresentou diferença significativa entre os grupos.

Tabela 10. Score Médio de Biópsia Tubular de Johnsen's (MJTBS) e incidência das alterações histopatológicas encontradas no testículo e epidídimo (cabeça/corpo) dos animais do grupo controle e tratados com ayahuasca, $\mathrm{n}(\%)$.

\begin{tabular}{|c|c|c|c|c|c|}
\hline & $\begin{array}{c}\text { Controle } \\
(n=12)\end{array}$ & $\begin{array}{c}1 X \\
(n=12)\end{array}$ & $\begin{array}{c}2 X \\
(n=12)\end{array}$ & $\begin{array}{c}4 X \\
(n=12)\end{array}$ & $\begin{array}{c}8 X \\
(n=10)\end{array}$ \\
\hline MJTBS & $7.52 \pm 0.17$ & $7.61 \pm 0.19$ & $7.48 \pm 0.15$ & $7.09 \pm 0.10$ & $7.60 \pm 0.25$ \\
\hline $\begin{array}{l}\text { Edema testicular } \\
\text { intenso }\end{array}$ & $0(0)$ & $1(8.3)$ & $0(0)$ & $3(25)$ & $0(0)$ \\
\hline $\begin{array}{l}\text { Esfoliação acentuada } \\
\text { de cél. germinativas }\end{array}$ & $1(8.3)$ & $2(16.6)$ & $1(8.3)$ & $3(25)$ & $2(20)$ \\
\hline Vacuolização tubular & $7(58.3)$ & $4(33.3)$ & $6(50)$ & $6(50)$ & $3(30)$ \\
\hline Necrose celular & $2(16.6)$ & $4(33.3)$ & $3(25)$ & $1(8.3)$ & $3(30)$ \\
\hline $\begin{array}{l}\text { Túbulos com epitélio } \\
\text { desorganizado }\end{array}$ & $2(16.6)$ & $0(0)$ & $4(33.3)$ & $5(41.6)$ & $1(10)$ \\
\hline $\begin{array}{l}\text { Túbulos com redução } \\
\text { do diâmetro }\end{array}$ & $3(25)$ & $2(16.6)$ & $3(25)$ & $5(41.6)$ & $3(30)$ \\
\hline $\begin{array}{l}\text { Células da linhagem } \\
\text { espermatogênica no } \\
\text { interior do ducto } \\
\text { epididimário }\end{array}$ & $7(58.3)$ & $6(50)$ & $8(66.6)$ & $9(75)$ & $7(70)$ \\
\hline $\begin{array}{l}\text { Infiltrado inflamatório } \\
\text { intersticial }\end{array}$ & $5(41.6)$ & $6(50)$ & $8(66.6)$ & $9(75)$ & $7(70)$ \\
\hline $\begin{array}{l}\text { Infiltrado inflamatório } \\
\text { perivascular }\end{array}$ & $2(16.6)$ & $1(8.3)$ & $1(8.3)$ & $1(8.3)$ & $1(10)$ \\
\hline
\end{tabular}

Valores do parâmetro MJTBS expressos em média \pm SEM. Resultados analisados pelo teste do Qui-quadrado.

A avaliação histopatológica do segmento cabeça/corpo do epidídimo revelou presença de poucas células da linhagem espermatogênica no interior do túbulo epididimário nos grupos tratados com ayahuasca e controle, não havendo diferenças significativas entre eles (Tabela 10; Figura 34B). Infiltrado inflamatório composto por macrófagos, linfócitos e plasmócitos foi encontrado no interstício (Figura 34C) e região perivascular principalmente na região da cabeça de forma discreta em todos os grupos, sem diferenças significativas (Tabela 10). A densidade espermática nas regiões da cabeça e corpo do epidídimo foi avaliada considerando a intensidade da 
alteração do volume espermático no interior do túbulo, que foi classificada como hipoespermia moderada $(+++)$, hipoespermia discreta $(++)$ e normal $(+)$. Não foram observadas diferenças significativas entre os grupos quanto à densidade espermática nessas regiões do epidídimo. A maioria dos animais apresentou uma densidade espermática normal, sem diferença entre os grupos controle e tratados (Figura 34A). Três animais do grupo controle e dois animais do grupo $4 \mathrm{X}$ apresentaram hipoespermia discreta e moderada. Dois animais do grupo $1 \mathrm{X}$ e um animal do grupo 8X apresentaram hipoespermia discreta (Figura 34B).
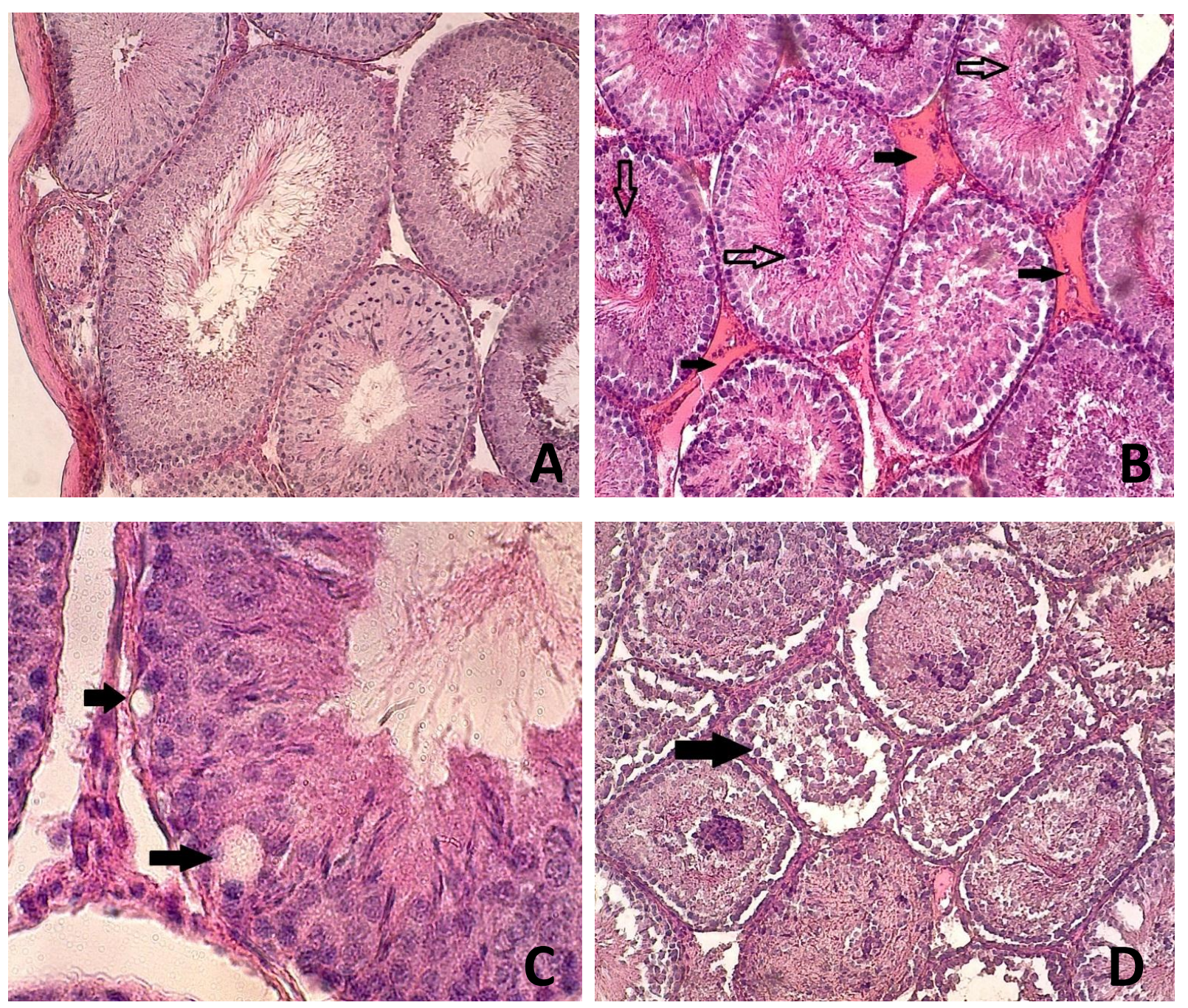

Figura 33. Cortes histológicos de testículo dos ratos do grupo controle $(n=12)$ e tratados com ayahuasca (grupos 1X, 2X, $4 X, n=12$; grupo $8 X, n=10$ ). A: Túbulos seminíferos de um animal do grupo controle com ausência de alterações (aumento 100X). B: Túbulos seminíferos de um animal do grupo $4 X$ apresentando esfoliação intensa de células germinativas (seta sem preenchimento) e edema intenso (setas com preenchimento) (aumento 100X). C: Túbulo de um animal do grupo 4X mostrando vacuolização (setas) (aumento 400X). D: Túbulos de um animal do grupo 2X com redução do diâmetro e desorganização celular (seta) (aumento 100X). Coloração H\&E. 

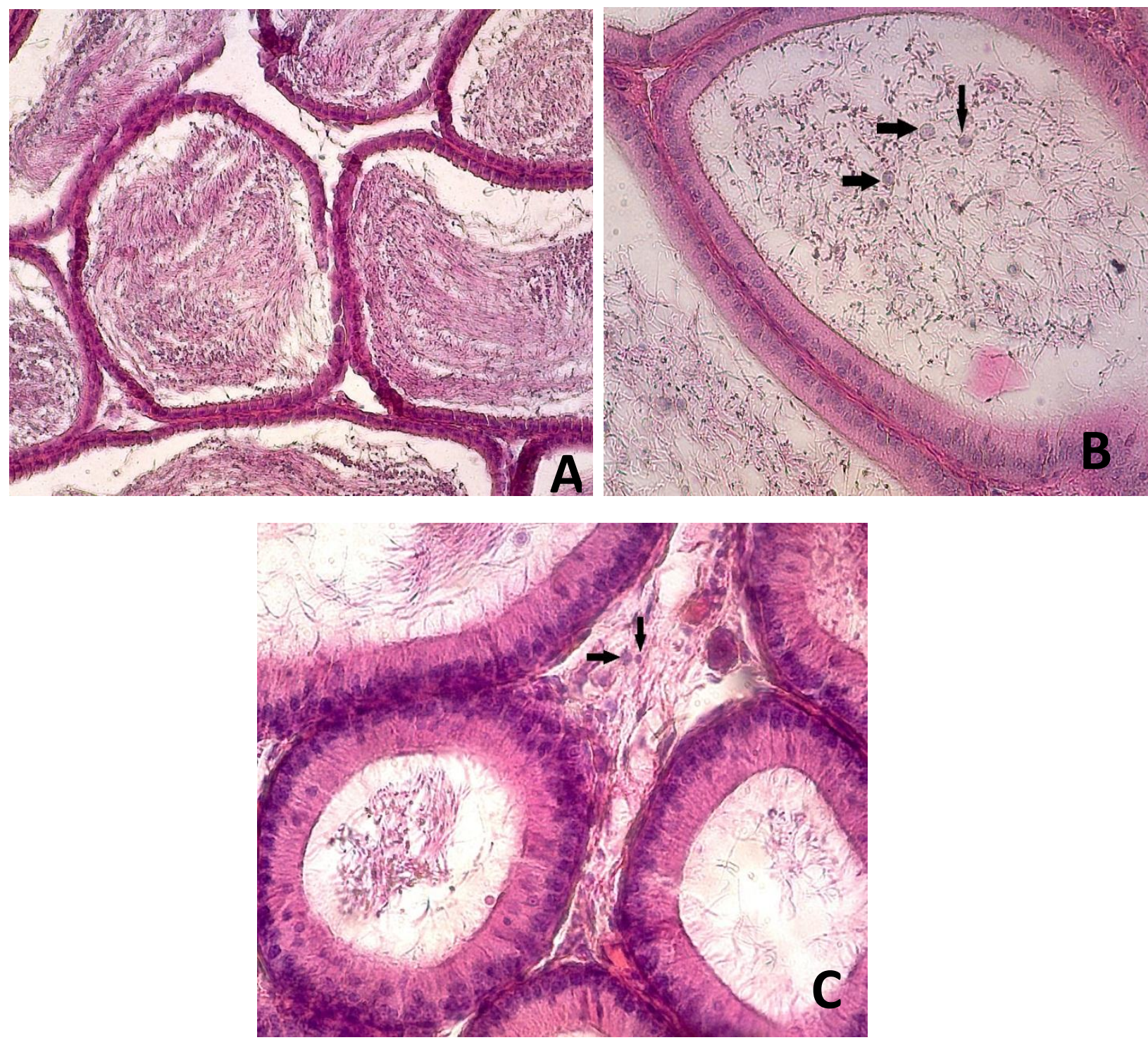

Figura 34. Seções longitudinais das regiões do corpo (A e B) e cabeça (C) do epidídimo dos animais do grupo controle $(n=12)$ e tratados com ayahuasca (grupos 1X, 2X, 4X, n=12; grupo 8X, n=10). A: Túbulo epididimário de um animal do grupo $1 \mathrm{X}$ com ausência de alterações e densidade espermática normal (aumento 100X). B: Túbulo epididimário de um animal do grupo controle apresentando células da linhagem espermatogênica (setas) e hipoespermia discreta a moderada (aumento 200X). C: Corte histológico de um animal do grupo 1X mostrando infiltrado inflamatório intersticial (setas) (aumento 200X). Coloração H\&E. 


\section{DISCUSSÃO}

Nosso estudo investigou os efeitos crônicos e reprodutivos da ayahuasca em ratos machos Wistar após exposição por via oral durante 70 dias alternados. As doses selecionadas coincidem com aquelas utilizadas no estudo de toxicidade reprodutiva feminina em ratas Wistar realizada previamente pelo nosso grupo de pesquisa (da Motta, 2013; Morais, 2014). Esse estudo demonstrou que a ingestão diária de ayahuasca em doses a partir de $4 \mathrm{X}$ a dose usual é letal para fêmeas após o quinto dia de administração, com os animais apresentando sinais de piloereção, tremores, convulsão, cromodacriorreia, lordose e cianose após. Resultado similar foi observado em pré-teste realizado no âmbito do presente estudo com ratos machos que receberam administração diária de ayahuasca na dose de $4 \mathrm{X}$.

Os resultados dos efeitos crônicos demonstraram que o ganho de peso corpóreo total ao final do tratamento e o consumo de ração verificado a cada três dias foi significativamente menor nos animais tratados com as maiores doses de ayahuasca ( $4 \mathrm{X}$ e $8 \mathrm{X}$ ), comparado aos outros grupos, porém o peso corpóreo ao final do tratamento foi significativamente menor apenas para o grupo tratado com a maior dose. Além disso, observou-se um aumento significativo do peso relativo do estômago e uma diminuição significativa do peso absoluto do baço nos animais tratados com ayahuasca na dose de $8 \mathrm{X}$ em relação ao grupo controle. Esses resultados sugerem uma possível toxicidade crônica da ayahuasca em ratos machos em exposições mais elevadas. Estudo realizado por da Motta (2013) demonstrou que a administração crônica diária de ayahuasca durante o período gestacional $\left(6^{\circ}\right.$ ao $21^{\circ} \mathrm{dia}$ ) provocou toxicidade materna, com diminuição significativa no consumo de ração nas doses de $1 \mathrm{X}, 4 \mathrm{X}$ e $8 \mathrm{X}$, aumento do peso do estômago nas ratas tratadas com as doses de $1 \mathrm{X}, 2 \mathrm{X}$ e $8 \mathrm{X}$ e dilatação do estômago e intestino nos animais do grupo de maior dose $(8 X)$.

Nossos resultados referentes à avaliação do potencial toxicológico reprodutivo masculino da ayahuasca mostraram que não houve alteração significativa na produção espermática diária nos animais tratados, embora o grupo de 8X tenha apresentado uma diminuição não significativa nesse parâmetro, mas uma diminuição significativa do peso médio dos testículos em relação ao grupo controle. Houve um aumento significativo nas dosagens de testosterona total nos 
animais tratados com ayahuasca na dose de $4 \mathrm{X}$. Também houve uma diminuição significativa da reserva espermática na cauda do epidídimo, assim como no tempo de trânsito espermático nesse mesmo grupo tratado, em relação ao grupo controle e ao grupo de 8X. Existe uma relação direta entre essas duas últimas variáveis, já que a redução da reserva espermática é resultado do menor tempo de trânsito espermático no epidídimo (Kempinas \& Klinefelter, 2014). Estudos mostram que o atraso no tempo de transporte do espermatozoide no epidídimo não altera a capacidade fértil dos gametas (Billups et al., 1990; Kempinas et al., 1998). Por outro lado, quando o tempo de trânsito é menor a fertilidade fica prejudicada, pois compromete o processo de maturação e aquisição da capacidade fértil (Fernandez et al., 2008; Klinefelter, 2002). Meistrich (1975) demonstrou que o tratamento com derivado do estradiol juntamente com a testosterona em ratos Wistar não afetou a função testicular, mas acelerou 0 tempo de transporte espermático e consequentemente diminuiu a reserva espermática no epidídimo. Diversos autores relatam a atuação de agentes tóxicos na diminuição da reserva espermática na cauda do epidídimo, mas sem alteração na produção espermática (Bellentani et al., 2011; Goyal et al., 2001; Klinefelter \& Suarez, 1997).

Nossos resultados também mostraram um aumento do peso relativo dos epidídimos dos animais do grupo de 4X em relação ao grupo de 8X. Essa alteração no peso pode estar relacionada com o aumento dos níveis sorológicos de testosterona, verificado nos animais desse grupo, já que se trata de um órgão andrógeno-dependente. Fernandez et al. (2008) verificou uma suposta relação entre a diminuição do peso dos órgãos reprodutivos com a diminuição dos níveis plasmáticos de testosterona em ratos Wistar tratados com dietilestilbestrol.

Estudos demonstram que o DMT se liga fortemente aos receptores serotoninérgicos do tipo $5-\mathrm{HT}_{2 \mathrm{~A}}$, além de agir como um substrato para o SERT o que leva a uma inibição da recaptação da serotonina, que permanece por mais tempo na fenda sináptica (Cozzi et al., 2009; Halberstadt, 2015; Nagai et al., 2007; Smith et al., 1998). Adicionalmente, os alcaloides $\beta$-carbolinícos presentes na infusão também inibem a recaptação de serotonina (Callaway et al., 1999; Cozzi et al., 2009). Outros estudos em animais e humanos demonstram uma relação direta entre o aumento dos níveis plasmáticos de testosterona induzido por tratamento e o aumento da densidade de sítios de recaptação de serotonina (SERT) em regiões do cérebro como córtex cingulado anterior, amídala, núcleo putamen, caudado e núcleo da rafe 
(Kranz et al., 2015), assim como de receptorores $5-\mathrm{HT}_{2 \mathrm{~A}}$ em algumas áreas cerebrais (Herrera-Pérez et al., 2013; Mcqueen et al., 1999; Sumner \& Fink, 1998; Kranz et al., 2015). Os resultados do presente estudo sugerem haver uma relação entre a administração crônica de ayahuasca e o aumento nos níveis plasmáticos de testosterona, verificado nos animais tratados com a dose de $4 \mathrm{X}$. Esse resultado sugere que pode estar ocorrendo um mecanismo endócrino compensatório em resposta ao suposto aumento dos níveis de serotonina na fenda sináptica e ao aumento da concentração de DMT nos animais tratados com a dose de 4X. Esse mecanismo envolveria o aumento da liberação de testosterona como sinal para o aumento da densidade de SERT, molécula responsável pela recaptação da serotonina de volta ao neurônio pré-sináptico, dessa forma haveria uma quantidade maior de transportadores SERTs na membrana celular, controlando assim os níveis altos de DMT e de serotonina na fenda sináptica. Mckenna (2004) afirma que o uso regular da ayahuasca, aparentemente, resulta em modificação da modulação serotoninérgica com aumento da densidade de transportadores de serotonina no cérebro. Há a hipótese de que as mudanças positivas de comportamento, relatadas por usuários da ayahuasca, estejam relacionadas com a elevação da quantidade desses transportadores que pode ocorrer com o uso crônico dessa infusão (Callaway et al, 1994).

O aumento dos níveis plasmáticos de testosterona não foi observado na dose $8 X$, que são comparáveis ao grupo controle, sugerindo uma resposta tipo bimodal. Esta observação pode ser explicada pelo envolvimento da testosterona no mecanismo de retroalimentação negativa, inibindo a liberação de $\mathrm{GnRH}$ no hipotálamo com consequente inibição da liberação de gonadotrofinas (LH e FSH) pela hipófise (Figura 7) (Aires, 2008). Outra hipótese é que os altos níveis de serotonina alcançados na dose $8 \mathrm{X}$ podem estar provocando uma dessensibilização dos receptores serotoninérgicos com consequente diminuição da densidade de SERT. Os receptores $5 \mathrm{HT}_{2 \mathrm{~B}}$ possuem um papel regulador na homeostase dos níveis de serotonina sináptica e podem participar do controle de SERT nos neurônios do núcleo da rafe, e uma vez inativados, a acumulação extracelular de serotonina induzida por inibidores seletivos de recaptação de serotonina (ISRS) é inibida (Diaz et al., 2012).

A análise histopatológica do testículo revelou algumas alterações em todos os grupos, distinguindo no grau de intensidade. A maior parte delas se apresentou de 
forma discreta e moderada, porém algumas lesões como edema e esfoliação de células germinativas se apresentaram de forma intensa em maior proporção nos animais tratados com ayahuasca na dose de 4X. Esfoliação de células germinativas pode ser resultado da perda de adesão entre as células de Sertoli e as células germinativas. O edema pode ocorrer como um resultado do aumento de fluido intersticial, e é sugestivo de lesão vascular (Lanning et al., 2002). As mudanças histológicas de degeneração, também interpretada como vacuolização tubular, foram encontradas em $58 \%$ dos animais do grupo controle. Essa lesão se inicia nas células de Sertoli e varia em grau, sendo relativamente estereotipada. A desorganização celular e esfoliação de células germinativas pode ser devida a falha no processo de espermiação, ou seja, falha na liberação dos espermatozoides no lúmen pelas células de Sertoli, ocorrendo fagocitose dos espermatozoides por essas células (Jubb, Kennedy, and Palmer's, 2007).

No testículo, o escore MJTBS é utilizado para avaliar a espermatogênese de acordo com a presença ou ausência dos diferentes tipos celulares existentes no epitélio seminífero (Johnsen, 1970). Escore menor indica mais espermátides presentes, mas sem espermátides tardias e sem espermatozoides no lúmen (Johnsen, 1970; Kanter, 2010). Esse estudo identificou um escore médio de 7.5 e 7.6 nos animais do grupo controle e tratados com ayahuasca nas doses de $1 \mathrm{X}, 2 \mathrm{X} \mathrm{e}$ $8 \mathrm{X}$, e um escore de 7.1 nos animais do grupo $4 \mathrm{X}$, apesar da diferença entre os grupos não ter sido significativa, sugerindo que a espermatogênese não foi afetada de forma significativa em nenhum grupo tratado com a ayahuasca.

A análise histopatológica do segmento cabeça/corpo do epidídimo revelou a presença de poucas células da linhagem espermatogênica no interior do túbulo epididimário em todos os grupos. Essa alteração pode estar relacionada com a esfoliação de células germinativas encontrada no testículo de todos os animais. Uma vez desprendidas das células de Sertoli, estas células podem migrar para o epidídimo. Geralmente, as lesões encontradas no epidídimo são consequentes dos eventos anormais que ocorrem no testículo (Lanning, 2002). Infiltrado inflamatório intersticial foi observado em todos os grupos. Essa alteração é frequentemente vista nos animais, ocorrendo em todas as regiões do epidídimo, porém sua etiologia não é conhecida. Os infiltrados consistem frequentemente de neutrófilos e linfócitos, e a forma mais significativa de manifestação da inflamação é a formação de granulomas 
(Kempinas \& Klinefelter, 2014). A presença dessa lesão não foi observada em nenhum animal.

A densidade espermática nas regiões da cabeça e corpo foi avaliada de forma semi-qualitativa, e não foi possível observar alterações significativas entre os grupos nesse parâmetro. A avaliação da contagem de espermatozoides na cauda do epidídimo revelou que os animais tratados com ayahuasca na dose de 4X obtiveram uma quantidade significativamente menor comparado ao grupo controle e ao grupo de 8X. Era esperado haver uma diminuição da densidade espermática também nas regiões superiores do epidídimo nesse grupo. Porém, Kempinas \& Klinefelter (2014) enfatiza que os efeitos tóxicos sobre a quantidade ou qualidade do esperma podem ocorrer na ausência de quaisquer alterações histopatológicas no epidídimo ou testículo, sendo necessária a detecção apenas por análise direta. Além disso, é possível ocorrer toxicidade em locais específicos do epidídimo, podendo ocorrer na região da cabeça ou da cauda. A densidade espermática pode refletir eventos dependentes do tempo no testículo, pois os espermatozoides presentes na cauda foram liberados pelo testículo aproximadamente duas semanas antes de sua chegada nessa região, enquanto os presentes na cabeça foram liberados pelo testículo alguns dias antes (Lanning, 2002). Portanto, os efeitos diferenciais na densidade espermática na cabeça/corpo e na cauda podem indicar que o tempo de um efeito tóxico é diferente em cada região analisada.

\section{CONCLUSÕES}

Esse estudo mostrou que a administração crônica de ayahuasca nas doses de $4 \mathrm{X}$ e $8 \mathrm{X}$ a cada dois dias, durante 70 dias, em ratos machos Wistar provocou certa toxicidade indicado pela diminuição do consumo médio de ração e do ganho de peso total desses animais. Os animais expostos à ayahuasca na dose de $4 \mathrm{X}$ apresentaram níveis mais altos de testosterona, o que provavelmente influenciou na aceleração do tempo de trânsito espermático e consequentemente na diminuição da reserva espermática na cauda do epidídimo. Neste sentido, estudos toxicológicos com os componentes ativos já descritos do chá, bem como um estudo mais completo do perfil químico desta infusão precisam ser realizados para esclarecer melhor o efeito da ayahuasca sobre o sistema reprodutivo de ratos machos. 


\section{CONSIDERAÇÕES FINAIS}

A administração crônica de ayahuasca nas doses selecionadas de forma intermitente não foi suficiente para produzir efeito ansiolítico e antidepressivo em ratos, efeito este já observado em estudos prévios em exposição única em doses mais altas. Portanto é necessário investigar se estes efeitos podem ocorrer após exposição diária da ayahuasca, em doses baixas, menores que $4 \mathrm{X}$ a dose usual, que pode levar os animal ao óbito.

O presente estudo mostrou que a ayahuasca possui potencial toxicológico reprodutivo na dose de $4 \mathrm{X}$ em ratos machos e sua ação sugere efeito bimodal, visto que os animais tratados com a maior dose (8X) não apresentaram alterações nos indicadores reprodutivos. Estudos que investiguem o papel dos componentes da ayahuasca na regulação dos níveis de testosterona, bem como de SERT no cérebro de ratos machos são necessários para investigar melhor esta ação tóxica.

A administração crônica de ayahuasca nas doses de 4X e 8X provocou toxicidade em ratos evidenciada por uma diminuição significativa do consumo de ração e do ganho de peso corpóreo nesses grupos e pela diminuição significativa do peso corpóreo ao final do tratamento nos animais tratados com a maior dose. No entanto, este tratamento crônico nas doses selecionadas não comprometeu as funções renais, hepática, pancreática e de metabolização lipídica, avaliadas por análise bioquímica sérica.

Esse estudo permitiu identificar um nível de efeito adverso não observado (no-observed-adverse-effect-level, NOAEL) da ayahuasca na dose de $2 \mathrm{X}$ em ratos Wistar machos, na qual os indicadores de toxicidade crônica, como ganho de peso corpóreo, consumo de ração e peso relativo dos órgãos, e indicadores de toxicidade reprodutiva foram estatisticamente iguais aos do grupo controle. Essa dose corresponde a $0,6 \mathrm{mg} / \mathrm{kg}$ pc de DMT, 6,6 mg/kg pc de harmina e $0,52 \mathrm{mg} / \mathrm{kg}$ pc de harmalina.

É importante ressaltar que na UDV e em outras religiões ayahuasqueiras, o uso ritualístico do chá ocorre uma vez a cada duas semanas, frequência bem menor que a utilizada no presente estudo (a cada dois dias). Os resultados deste estudo não contradizem estudos anteriores que indicam que o uso ritualístico da ayahuasca é seguro para o homem, incluindo no que se refere ao potencial reprodutivo masculino. 


\section{REFERÊNCIAS BIBLIOGRÁFICAS}

Aires M. M. (2008). Gônadas. In Fisiologia (Guanabara ., p. 1051). Rio de Janeiro.

Amann, R. P. (1982). Use of Animal Models for Detecting Specific Alterations in Reproduction. Fundamental and Applied Toxicology, 2, 13-26.

Anderson, B. T., Labate, B. C., Meyer, M., Tupper, K. W., Barbosa, P. C. R., Grob, C. S., ... McKenna, D. (2012). Statement on ayahuasca. International Journal of Drug Policy, 23(3), 173-175.

Armario, A., Gavaldh, A., \& Marti, O. (1988). Forced swimming test in rats : effect of desipramine administration and the period of exposure to the test on struggling behavior, swimming, immobility and defecation rate. European Journal of Pharmacology, 158, 207-212.

Ayflegül, Y., Gönül, A. S., \& Tamam, L. (2002). Mechanism of Actions of Antidepressants: Beyond the Receptors Cellular Receptors. Bulletin of Clinical Psychopharmacol, 12(4), 194-200.

Bellentani, F. F., Fernandes, G. S. a, Perobelli, J. E., Pacini, E. S. a, Kiguti, L. R. a, Pupo, A. S., \& Kempinas, W. D. G. (2011). Acceleration of sperm transit time and reduction of sperm reserves in the epididymis of rats exposed to sibutramine. Journal of Andrology, 32(6), 718-24.

Billups, K. L., Tillman, S., \& Chang, T. S. (1990). Ablation of the inferior mesenteric plexus in the rat: alteration of sperm storage in the epididymis and vas deferens. The Journal of Urology, 143(3), 625-9.

Blazak, W. F., Ernst, T. L., \& Stewart, B. E. (1985). Potential Indicators of Reproductive Toxicity: Testicular Sperm Production and Epididymal Sperm Number, Transit Time, and Motility in Fischer 344 Rats. Toxicological Sciences, 5(6), 1097-1103.

Brito, A. R. M. S. A., Costa, M. A. M., Carvalho, J. E., Dias, P. C. (1994). Efeitos farmacológicos do decocto (hoasca) de Banisteriopsis caapi e Psychotria viridis em camundongos. In: IX Reunião anumal da federação da sociedades de biologia experimental (fesbe), Caxambu, MG, 1994. Resumos da IX reunião da FESBE. Editora da FESBE, São Paulo, SP. (doc. n V.V.2.41), 203.

Brito, G. d. S. (2004). Farmacologia humana da Hoasca (chá preparado de plantas alucinógenas usado em contexto ritual no Brasil). Labate, B. C., Araújo, W. S, organizadores. O uso ritual da ayahuasca, 2 ed, Campinas: Mercado da letras, 623-651.

Buckholtz, N. S.,\& Boggan, W. O. (1977) Monoamine oxidase inhibition in brain and liver produced by $\beta$-carbolines: Structure-Activity relationships and substrate specificity. Biochemical Pharmacology, 26, 1991-1996. 
Callaway, J. C., Airaksinen, M. M., Mckenna, D. J., Brito, G. S., \& Grob, C. S. (1994). Platelet serotonin uptake sites increased in drinkers of ayahuasca. Psychopharmacology, 116, 385-387.

Callaway, J. C., Raymon, L. P., Hearn, W. L., Mckenna, D. J., Grob, C. S., Brito, G. S., ... Postal, C. (1996). Quantitation of N, N-Dimethyltryptamine and Harmala Alkaloids in Human Plasma after Oral Dosing with Ayahuasca. Journal of Analytical Toxicology, 20, 492-497.

Callaway, J. C., \& Grob, C. S. (1998). Ayahuasca preparations and serotonin reuptake inhibitors: a potential combination for severe adverse interactions. Journal of Psychoactive Drugs, 30(4), 367-9.

Callaway, J. ., McKenna, D. ., Grob, C. ., Brito, G. ., Raymon, L. ., Poland, R. ., ... Mash, D. . (1999). Pharmacokinetics of Hoasca alkaloids in healthy humans. Journal of Ethnopharmacology, 65(3), 243-256.

Callaway, J. C., Grob, C. S., McKenna, D. J., Nichols, D. E., Shulgins, A., Tupper, K. W. (2006). A demand for clarity regarding a case report on the ingestion of 5methoxy-N, N-dimethyltryptamine (5-Meo-DMT) in a ayahuasca preparation. Journal of Analytical Toxicology, 30(6), 406-407.

Cazenave, S. O. S. (2000). Banisteriopsis caapi: ação alucinógena e uso ritual. Revista de Psiquiatria clínica, 27(1), 1-6.

CONAD. Conselho Nacional de Políticas sobre Drogas. (2004), 5-6. Retrieved from http://www.obid.senad.gov.br/portais/OBID/biblioteca/documentos/Legislacao/32 7030.pdf.

CONAD. Conselho Nacional de Plíticas sobre Drogas. (2010), Resolução nº 1 de 25 de janeiro de 2010. Diário Oficial da União.

CONFEN. Conselho Federal de Entorpecentes. (1986), Resolução $n^{\circ} 6$ de 4 de fevereiro de 1986.

Convention on Psychotropic Substances, entry into force August (1971) 16, 1976, 1019, U.N.T.S. 175.

Corrêa, J., Amorin, V., Nogueira, D., Soares, E., Guerra, F., Fernandes, G., ... Esteves, A. (2014). Neuronal quantification in mice cerebral cortex under use of Ayahuasca tea. Revista Neurociências, 22(03), 388-391.

Corregiari, F. (2009). Receptores sigma 1: Um novo alvo para o tratamento farmacológico da depressão? Revista Brasileira de Medicina, 66(8), 245-48.

Costa, M. C. M., Figueiredo, M. C., Cazenave, S. O. S. (2005). Ayahuasca: Uma abordagem toxicológica do uso ritualístico. Revista de Psiquíatria Clínica, 32(6), 310-318. 
Cozzi, N. V., Gopalakrishnan, A., Anderson, L. L., Feih, J. T., Shulgin, A. T., Daley, P. F., \& Ruoho, A. E. (2009). Dimethyltryptamine and other hallucinogenic tryptamines exhibit substrate behavior at the serotonin uptake transporter and the vesicle monoamine transporter. Journal of Neural Transmission, 116(12), 1591-1599.

da Motta, L. S. G. da. (2013). Toxicidade aguda, neurotoxicidade, toxicidade reprodutiva e embriotoxicidade do chá ayahuasca (Banisteriopsis caapi e Psychotria viridis) em ratas Wistar. Dissertação de mestrado. Faculdade de Ciências da Saúde. Universidade de Brasília.

Detke, M. J., Rickels, M., \& Lucki, I. (1995). Active behaviors in the rat forced swimming test differentially produced by serotonergic and noradrenergic antidepressants. Psychopharmacology, 121(1), 66-72.

Detke, M. J., Johnson, J., \& Lucki, I. (1997). Acute and chronic antidepressant drug treatment in the rat forced swimming test model of depression. Experimental and Clinical Psychopharmacology, 5(2), 107-112.

Diaz, S. L., Doly, S., ... Maroteaux, L. (2012). 5-HT2B receptors are required for serotonin-selective antidepressant actions. Molecular Psyquiatry, 17(2), 154163.

Dos Santos, R. G. (2013). A critical evaluation of reports associating ayahuasca with life-threatening adverse reactions. Journal of Psychoactive Drugs, 45(2), 17988.

Durand, M., Berton, O., Aguerre, S., Edno, L., Combourieu, I., Mormede, P., Chaouloff, F. (1999). Effects of repeated fluoxetine on anxiety-related behaviours, central serotoninergic systems, and the corticotropic axis in SHR and WKY rats. Neuropharmacology, 38, 893-907.

EPA. Guidelines for Reproductive Toxicity Risk Assessment. (1996), 61(212), 56274-56322.

Fantegrossi, W. E., Murnane, K. S., \& Reissig, C. J. (2008). The behavioral pharmacology of hallucinogens. Biochemical Pharmacology, 75(1), 17-33.

Fernandez, C. D. B., Porto, E. M., Arena, A. C., \& Kempinas, W. D. G. (2008). Effects of altered epididymal sperm transit time on sperm quality. International Journal of Andrology, 31(4), 427-437.

Ferreira, C. A. (2008). O vinho das almas: xamanismo e cristianismo no santo daime. Pontifíca Universidade Católica de São Paulo.

Figueroa, A. R. M. (2012). Avaliação dos efeitos neurotóxicos do chá ayahuasca Avaliação dos efeitos neurotóxicos do chá ayahuasca. Universidade de Sáo Paulo. 
Fontanilla, D., Johannessen, M., Hajipour, A. R., Cozzi, N. V., Jackson, M. B., \& Ruoho, A. E. (2009). The Hallucinogen N,N-Dimethyltryptamine (DMT) Is an Endogenous Sigma-1 Receptor Regulator. Science, 323(5916), 934-937.

Fortunato, J. J., Réus, G. Z., Kirsch, T. R., Stringari, Stertz, L., Kapczinsk, F., Pinto, J. P., Hallak, J. E, Zuardi, A. W., Crippa, J. A., Quevedo, J. (2009). Acute harmine administration induces antidepressive-like effects and increase BNDF levels in the rat hippocampus, Progress in Neuro-Psychopharmacology \& Biological Psychiatry, 33(8), 1425-30.

Fortunato, J. J., Réus, G. Z., Kirsch, T. R., Stringari, Stringari, R. B,. Fries, G.R,. Kapczinsk, F., Hallak, J. E, Zuardi, A. W., Crippa, J. A., Quevedo, J. (2010). Chronic administration of harmine elicts antidepressant-like effects and increases BDNF levels in rat hippocampus. Journal of Neural Transmission, 117(10), 1131-7.

Franco, M. M., Gomez, F. R., Tamez, G. P., Tamez, G. R., Castillo, L. L., Rodríguez, P. C. (2003). In vitro immunopotentiating properties and tumour cell toxicity induced by Lophophora williamsii (peyote) cactus methanolic extract. Phytotherapy research: PTR, 17(9), 1076-81.

Gable, R. S. (2007). Risk assessment of ritual use of oral dimethyltryptamine (DMT) and harmala alkaloids. Addiction, 102(1), 24-34.

Gareri, P., Stilo, G., Bevacqua, I., Mattace , R., Ferreri, G., De Sarro, G. (1998). Antidepressant drugs in the elderly. General Pharmacology, 30(4), 465-75.

Gilbert, S. F. (2003). Biologia do desenvolvimento, 5. ed. Ribeirão Preto , SP: FUNPEC editora, p. 994.

Golan, D. E. (2009). Farmacologia da Neurotransmissão Serotoninérgica e Adrenérgica Central. In Princípios de Farmacologia - A base Fisiopatológica da Farmacoterapia (2nd ed., p. 914).

Gomes, K. S., Neto, E. F. d. C., Monte, K. C. d. S., Acco, B., Nogueira, P. J. d. C., Souza, R. L. N. d. (2009). Contrasting effects of acude and chronic treatment with imipramine and fluoxetine on inhibitory avoidance and escape responses in mice exposed to the elevated T-maze. Brain Research Bulletin, 78, 323-327.

Goulart, S. L. (1996). Raízes Culturais do Santo Daime. Dissertação de mestrado. Antropologia, Universidade de São Paulo.

Goyal, H. O., Braden, T. D., Mansour, M., Williams, C. S., Kamaleldin, A., \& Srivastava, K. K. (2001). Diethylstilbestrol-treated adult rats with altered epididymal sperm numbers and sperm motility parameters, but without alterations in sperm production and sperm morphology. Biology of Reproduction, 64(3), 927-934. 
Gray, V. C., \& Hughes, R. N. (2015). Drug-, dose- and sex-dependent effects of chronic fluoxetine, reboxetine and venlafaxine on open-field behavior and spatial memory in rats. Behavioural Brain Research, 281, 43-54.

Grob, C. S., McKenna, D. J., Callaway, J. C., Brito, G. S., Neves, E. S., Oberlaender, G., ... Boone, K. B. (1996). Human Psychopharmacology of Hoasca, A Plant Hallucinogen Used in Ritual Context in Brazil. The Journal of Nervous and Mental Disease, 184(2), 86-94.

Guide for the Care and Use the Laboratory Animals. (2011). Nacional Research Council (US). Washington: Nacional Academies Press, 8th, p. 220.

Halberstadt, A. L. (2015). Recent advances in the neuropsychopharmacology of serotonergic hallucinogens. Behavioural Brain Research, 277, 99-120.

Hall, C. S. (1934). Emotional behavior in the rat. I. Defecation and urination as measures of individual defferences in emotionality. Journal of Comparative Psychology, 18(3), 385.

Halpern, J. H. (2004). Hallucinogens and dissociative agents naturally growing in the United States. Pharmacology \& Therapeutics, 102(2), 131-8.

Handley, S. L. \& Mithani, S. (1984). Effect of alpha-adrenoceptor agonists and antagonists in a maze-exploration model of fear-motivated behaviour. NaunynSchmiedeberg's Archives of Pharmacology, 327(1), 1-5.

Harvey, R., Champe, P. C. (1998). Farmacologia llustrada. Artimed, 2ed, 478.

Herrera-Pérez, J. J., Fernández-Guasti, A., \& Martínez-Mota, L. (2013). Brain sert expression of male rats is reduced by aging and increased by testosterone restitution. Neuroscience Journal, 2013, 201909.

Hogg, S. (1996). A review of the validity and variability of the elevated plus-maze as an animal model of anxiety. Pharmacology Biochemistry and Behavior, 54(1), 21-30.

Johnsen, S. G. (1970). Testicular biopsy score count - a method for registration of spermatogenesis in human testes: normal values and results in 335 hypogonadal males. Hormones, 1, 2-25.

Jubb, K.V.F., Kennedy, P.C., Palmer, N. (2007). Jubb, Kennedy and Palmer's pathology of domestic animals. New York: Elsevier. 5ht ed, 572-601.

Kanter, M. (2010). Protective effects of melatonin on testicular torsion/detorsioninduced ischemia-reperfusion injury in rats. Experimental and Molecular Pathology, 89(3), 314-20.

Karpova, N. N., Pickenhagen, A., Lindholm, J., Tiraboschi, E., Ágústsdóttir, A., Antila, H., ... Castrén, E. (2011). Fear erasure in mice requires synergy between antidepressant drugs and extinction training. Science, 334(6063), 1731-1734. 
Kempinas, W. D. G., \& Klinefelter, G. R. (2014). Interpreting histopathology in the epididymis. Spermatogenesis, 4(2), 1-12.

Kempinas, W. D. G., Suarez, J. D., Roberts, N. L., Strader, L., Ferrell, J., Goldman, J. M., \& Klinefelter, G. R. (1998). Rat epididymal sperm quantity, quality, and transit time after guanethidine. Biology of Reproduction, 59, 890-896.

Klinefelter, G. R., \& Suarez, J. D. (1997). Toxicant-induced acceleration of epididymal sperm transit: Androgen-dependent proteins may be involved. Reproductive Toxicology, 11(4), 511-519.

Klinefelter, G. R. (2002) Actions of toxicants on the structure and function of the epididymis. In: The Epididymis - From Molecules to Clinical Practice (eds B. Robaire \& B. T. Hin- ton), pp. 353-369. Kluwer Academic/Plenum Publisher, New York

Kranz, G. S., Wadsak, W., Kaufmann, U., Savli, M., Baldinger, P., Gryglewski, G., ... Lanzenberger, R. (2015). High-dose testosterone treatment increases serotonin transporter binding in transgender people. Biological Psychiatry, 78(8), 525-33.

Kulkarni, M., Hayden, C., Kayes, O., \& Hayden, C. (2014). Recreational drugs and male fertility. Trends in Urology \& Mens Health, 19-23.

Labate, B. C., Araújo, V. S. (2002). O uso ritual da ayahuasca. Porto Alegre. Campinas: Mercado das letras. 686.

Labate, B. C., Macrae, E., Goulart, S. L., Frenopoulo, C., \& Meyer, M. (2010). Brazilian ayahuasca religions in perspective, (2009), 1-20.

Labate, B. C., \& Feeney, K. (2012). Ayahuasca and the process of regulation in Brazil and internationally: implications and challenges. The International Journal on Drug Policy, 23(2), 154-61.

Lamprea, M. R., Cardenas, F. P., Setem, J., Morato, S. (2008). Thigmotactic responses in an open-field. Brazilian Journal of Medical and Biological Research, 41(2), 135-40.

Lanning, L. L., Creasy, D. M., Chapin, R. E., Mann, P. C., Barlow, N. J., Regan, K. S., \& Goodman, D. G. (2002). Recommended approaches for the evaluation of testicular and epididymal toxicity. Toxicologic Pathology, 30(4), 507-520.

Lei Arouca. Lei $\mathrm{n}^{\circ} 11.794$, de 8 de outubro de 2008. Disponível em http://www.planalto.gov.br/ccivil_03/_ato2007-2010/2008/lei//11794.htm.

Lozano, G. M., Bejarano, I., Espino, J., González, D., Ortiz, A., García, J.F., Rodríguez, A.B., Pariente, J.A. (2009). Relationship between caspase activity and apoptotic markers in human sperm in response to hydrogem peroxide and progesterone. Journal of Reproduction and Development, 55(6), 615-621. 
Macrae, E., \& Ph, D. (2004). The ritual use of ayahuasca by three Brazilian religions $1,27-45$.

Mar, A., Spreekmeester, E., Rochford, J. (2000). Antidepressants preferentially enhance habituation to novelty in the olfactory bulbectomized rat. Psychopharmacology, 150(1), 52-60.

Martinez, S. T., Almeida, M. R., e Pinto, A. C. (2009). Alucinógenos naturais: um voo da Europa Medieval ao Brasil. Química Nova, 32(9), 2501-2507.

McKenna, D. J. T. G. H. N. and A. F. (1984). Monoamine oxidase inhibitors in south american hallucinogenic plants: tryptamine and $\beta$-carboline constituentes of ayahuasca. Journal of Ethnopharmacology, 10, 195-223.

Mckenna, D. J., Repke, D. B., Lo, L., \& Peroutka, S. J. (1990). Differential interactions of indolealkylamines with 5-hydroxytryptamine receptor subtypes. Neuropharmacology, 29(3), 193-198.

McKenna, D. J. (2004). Clinical investigations of the therapeutic potential of ayahuasca: rationale and regulatory challenges. Pharmacology \& Therapeutics, 102(2), 111-29.

Mcqueen, J. K., Wilson, H., Sumner, B. E. H., \& Fink, G. (1999). Serotonin transporter (SERT) mRNA and binding site densities in male rat brain affected by sex steroids. Molecular Brain Research, 63, 241-247.

Meistrich, M. L. (1975). Alteration of epididymal sperm transport and maturation in mice by oestrogen and testosterona. Nature, 258(13), 145-147.

Melo Junior, W. (2014). Estudo do perfil genotóxico, citotóxico, neurocomportamental e bioquímico da ayahuasca em ratos Wistar tratados com dose única. Dissertação de mestrado. Faculdade de Ciências da Saúde, Universidade de Brasília.

Moser, V. C. (2011). Functional assays for neurotoxicity testing. Toxicologic Pathology, 39(1), 36-45.

Morais, J. A. de. (2014). Toxicidade Aguda e Crônica do chá ayahuasca (Banisteriopsis caapi e Psychotria viridis), por análise Histopatológica em ratas Wistar. Dissertação de mestrado. Faculdade de Ciências da Saúde, Universidade de Brasília.

Morgan, D. J., Muller, C. H., Murataeva, N. a, Davis, B. J., \& Mackie, K. (2012). $\Delta 9$ Tetrahydrocannabinol $(\triangle 9-\mathrm{THC})$ attenuates mouse sperm motility and male fecundity. British Journal of Pharmacology, 165(8), 2575-2583.

Nagai, F., Nonaka, R., \& Satoh Hisashi Kamimura, K. (2007). The effects of nonmedically used psychoactive drugs on monoamine neurotransmission in rat brain. European Journal of Pharmacology, 559(2-3), 132-137. 
Naranjo, P. (1986). El ayahuasca en la arqueologia ecuatoriana. America Indígena, $46(1), 115-127$.

Netter, F. H. (2000). Atlas de Anatomia Humana. 2 ed. Porto Alegre: Artmed

O'Donnell, L., Robertson, K. M., Jones, M. E., \& Simpson, E. R. (2001). Estrogen and Spermatogenesis 1. Endocrine Reviews, 22(3), 289-318.

OECD (organization for economic co-operation and development) 2003. Guideline for Testing of Chemicals. Proposal for updating guideline 208.

Oliveira, C. D. R., Moreira, C. Q., de Sá, L. R. M., de Souza Spinosa, H., \& Yonamine, M. (2010). Maternal and developmental toxicity of ayahuasca in Wistar rats. Birth Defects Research Part B: Developmental and Reproductive Toxicology, 89(3), 207-212.

Onyije, F. M. (2012). Drug: a major cause of infertility in male. Asian Journal of Madical and Pharmaceutical Researches, 2(2), 30-37.

Orgebin-Crist, M.-C. (1969). Studies on the function of the epididymis. Biology of Reproduction, 1, 155-175.

Orgebin-Crist, Marie-Claire, \& Nader, J. (1978). The maturation of rabbit epididymal spermatozoa in organ culture: inhibition by antiandrogens and inhibitors of ribonucleic acid and protein synthesis. Endocrinology, 103(1), 46-53.

Ott, J. (1999). Pharmahuasca: human pharmacology of oral DMT plus harmine. Journal of Psychoactive Drugs, 31(2), 171-77.

Pellow, S., Choping, P., File, S. E., Briley, M. (1985). Validation of open closed arms entries in an elevated plus-maze as a measure of anxiety in the rat. Journal of Neuroscience Methods, 14(3), 149-67.

Pic-Taylor, A., da Motta, L. G., de Morais, J. A., Junior, W. M., Santos, A. de F. A., Campos, L. A., ... Caldas, E. D. (2015). Behavioural and neurotoxic effects of ayahuasca infusion (Banisteriopsis caapi and Psychotria viridis) in female Wistar rat. Behavioural Processes, 118, 102-10.

Pires, A. P. S., Oliveira, C. D. R., Yonamine, M. (2010). Ayahuasca: Uma revisão dos aspéctos farmacológicos e toxicológicos. Revista de Ciências Farmacêuticas Básica e Aplicada, 31(1), 15-23.

Porsolt, R. D., Anton, G., Blavet, N., Jalfre, M. (1978). Behavioural dispair in rats: a new model sensitive to antidepressant treatments. European Journal of pharmacology, 47(4), 379-91.

Portaria SVS/MS n`344 da ANVISA, de 12 de maio de 1998, Brasília. 
Prut, L., \& Belzung, C. (2003). The open field as a paradigm to measure the effects of drugs on anxiety-like behaviors: a review. European Journal of Pharmacology, $463(1-3), 3-33$.

Qu, S. J., Wang, G. F., Duan, W. H., Yau, S. Y., Zuo, J. P., Tan, C. H., Zhu, D. Y. (2011). Tryptamine derivatives as novel non-nucleosidic inhibitors against hepatites B virus. Bioorganic and Medicinal Chemistry, 19, 3120-3127.

Quinteiro, M. M. d. C., Teixeira, D. C., Moraes, M. G. d., Silva, J. G. d. (2006). Anatomia foliar de Psychotria viridis Ruiz \& Pav. (Rubiaceae). Revista Universidade Rural, Série Ciências da Vida, Rio de Janeiro, EDUR, 26(2), 3041.

Ramos, A. (2008). Animal models of anxiety: do I need multiple tests? Trend in Pharmacological Sciences, 29(10), 493-98.

Robb, G. W., Amann, R. P., \& Killian, G. J. (1978). Daily sperm production and epididymal sperm reserves of pubertal and adult rats. Journal of Reproduction and Fertility, 54, 103-107.

Rodgers, R. J., Dalvi, A., \& Holmes, A. (1997). Animal models of anxiety: an ethological perspective. Brazilian Journal of Medical and Biological Research, 30, 289-304.

Sadler, T. W. (2011). Medical Embryology (12th ed., p. 384).

Santos, P. R. S., Carrara, T. V. B., Silva, L. C. S., Silva, A. R., Oliveira, M. F e Neto, A. C. S. (2011). Caracterização morfológica e frequência dos estádios do ciclo do epitélio seminífero em préas (Galea spixii Wagler, 1831) criados em cativeiro. Pesquisa Veterinária Brasileira, 31(1), 18-24.

Santos , A. C., Azevedo, B. R. D. M. S., Pereira, N. K., Irulegui, R. D. S. C \& Baracho, N, C, D, V. (2013). Efeitos cardiovasculares renais e hepáticos produzidos pela administração crônica de ayahuasca em ratos hipertensos/cardiovascular, Renal and hepatics effects produced by chronic administration of ayahuasca in hypertensive rats. Revista ciências em saúde, 3(4), 21-38.

Schenberg, E. E. (2013). Ayahuasca and cancer treatment. SAGE Open Medicine, 1.

Schultes, R. E. (1982). The beta-carboline hallucinogens of South America. Journal of Psychoactive Drugs, 14(3), 205-20.

Sciences, H. L., Wellcome, G., \& Sequani. (2000). Industrial reproductive toxicology ( irdg ) computer assisted sperm analysis ( casa ) group Rat Sperm Morphological Assessment Edition 1 October 2000 Huntingdon Life Sciences Sequani Glaxo Wellcome.

Seed, J., Chapin, E., Clegg, E. D., Dostal, L. A., Foote, H., Hur, M. E., ... Agency, U. S. E. P. (1996). Methods for assessing sperm motility, morphology, and counts 
in the rat, rabbit, and dog: a consensus report. Reproductive Toxicology, 10(3), 237-244.

Shanon, B. (2003). Os Conteúdos das visões da ayahuasca. Mana, 9(2), 109-152.

Sharma, P., \& Singh, R. (2010). Protective role of curcumin on lindane induced reproductive toxicity in male Wistar rats. Bulletin of Environmental Contamination and Toxicology, 84(4), 378-84.

Silva, L. O. (2004). Estudo sobre o castigo simbólico, ou peia, do culto do Santo Daime. Dissertação de mestrado. Ciências da Religião. Pontífica Universidade Católica, São Paulo.

Sklerov, J., Moore, K. A., King, T., \& Fowler, D. (2005). A Fatal Intoxication Following the Ingestion of 5-Methoxy-N , N-Dimethyltryptamine in an Ayahuasca Preparation *. Journal of Analytical Toxicology, 29, 838-841.

Slattery, D. a, \& Cryan, J. F. (2012). Using the rat forced swim test to assess antidepressant-like activity in rodents. Nature Protocols, 7(6), 1009-14.

Slott, V. L., Suarez, J. D., and Perreault, S. D. (1991). Rat sperm motility analysis: Methodologic considerations. Reproductive Toxicology, 5, 449-458.

Smith, R. L., Canton, H., Barrett, R. J., \& Sanders-Bush, E. (1998). Agonist properties of N,N-dimethyltryptamine at serotonin 5-HT2A and 5-HT2C receptors. Pharmacology, Biochemistry, and Behavior, 61(3), 323-30.

Souza, F. G. de M. e. (1999). Tratamento da depressão. Revista Brasileira de Psiquiatria, 21, 18-23.

Strader, L. F., Linder, R. E., \& Perrbault, S. D. (1996). Comparison of rat epididymal sperm counts by ivos HTM-IDENT and hemacytometer. Reproductive Toxicology, 10(6), 529-533.

Sujarit, S., \& Pholpramool, C. (1985). Enhancement of sperm transport through the rat epididymis after castration. Journal of Reproduction and Fertility, 74(2), 497502.

Sumner, B. E. H., \& Fink, G. (1998). Testosterone as well as estrogen increases serotonin $2 A$ receptor $m R N A$ and binding site densities in the male rat brain. Molecular Brain Research, 59, 205-214.

Tittarelli, R., Mannocchi, G., Pantano, F., \& Romolo, F. S. (2015). Recreational use , analysis and toxicity of tryptamines. Current Neuropharmacology, 13, 26-46.

Topping, D. M. (1998). Ayahuasca and cancer: one man's experience. Bull Multidiscip Assoc Psychedelic Stud, 8, 22-26.

Tupper, K. W. (2008). The globalization of ayahuasca: harm reduction or benefit maximization? The International Journal on Drug Policy, 19(4), 297-303. 
Vignera, S. L., Condorelli, R. A., Barlecia, G., Vicari, E., and Calogero, A. E. (2013). Does alcohol have any effect on male reproductive function? A review of literature. Asian Journal of Andrology, 15, 221-225

Vives, Sara Gonzales, García-albea, J. (2012). Exceptional states of consciousness and psychotropic substance consumption. Actas Esp Psiquiatr, 40(1957), 96103.

Willner, P. (1984). The validity of animal models of depression. Psychopharmacology, 83, 1-16.

Working, P. K. (1988). Male reproductive toxicology: comparison of the human to animal models. Environmental Health Perspectives, 77, 37.

Wyrobek, A. J., \& Bruce, W. R. (1975). Chemical induction of sperm abnormalities in mice. Proceedings of the National Academy of Sciences EUA, 72(11), 44254429. 


\section{ANEXO I - APROVAÇÃO DO COMITÊ DE ÉTICA}

Universidade de Brasilia

Instituto do Ciéncias Biológicas

Brasilia, 05 de maio de 2011

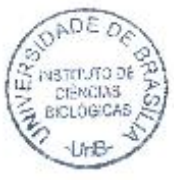

DECLARAÇĀO

Declaramos que o projeto intitulado "AVALIAÇĀO TOXICOLÓGICA DO CHÁ AYAHUASCA E DE SEUS COMPONENTES BIOATIVOS EM RATOS: DOSE LETAL AGUDA, COMPORTAMENTO, TOXICIDADE REPRODUTIVA E EMBRIOTOXICIDADE", UNBDOC N." 107766/2010, sob rcsponsabilidade da Profa. Eloisa Dutra Caldas, foi avaliado c aprovado pclo Comitc de Ética no Uso Animal (CEUA) do Instituto de Ciências Biológicas da Universidade de Brasilia

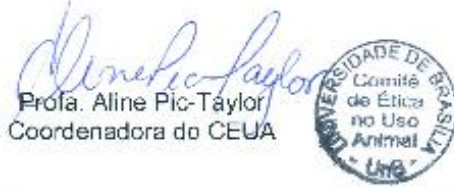

